DEPARTMENT OF THE INTERIOR

UNITED STATES GEOLOGICAL SURVEY

GEORGE OTIS-SMITH, DIRECTOR

BULLETIN 456

\title{
OIL AND GAS FIELDS
}

OF THE

\section{CARNEGIE QUADRANGLE, PENNSYLVANIA}

BY

- MALCOLM J. MUNN

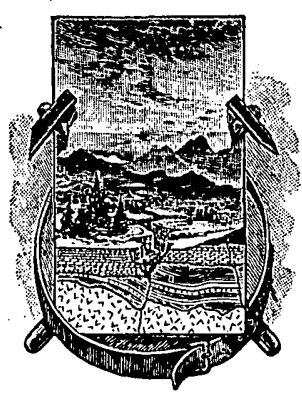

W A SHINGTON

GOVERNMENT PRINTING OFEIOE 



\section{CONTENTS.}

Introdiction

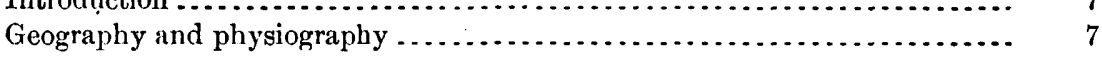

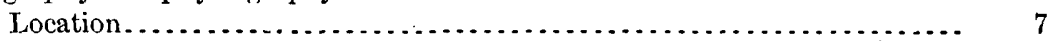

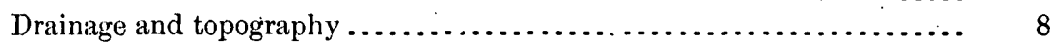

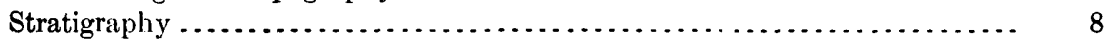

General character of the rocks $\ldots \ldots \ldots \ldots \ldots \ldots \ldots \ldots, \ldots \ldots \ldots \ldots, 8$

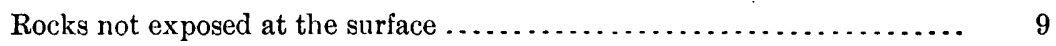

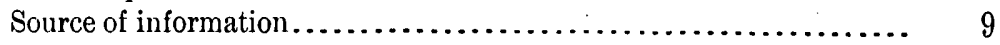

Devonian system........................................ 11

Devonian (?) system ....................................... 13

Catskill (?) formation................................ 13

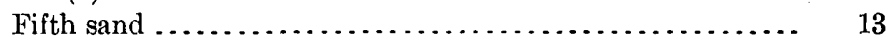

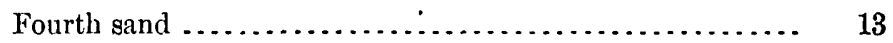

Third or Gordon sand and Third or Gordon Stray sand ..... 14

Bowlder (?) sand........................... 14

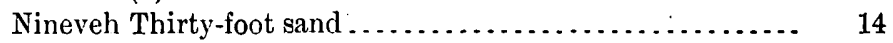

Carboniferous system ..................................... 15

Mississippian series................................... 15

Pocono formation ................................. 15

Hundred-foot sand ............................. 15

Murrysville or Butler Thirty-foot sand............... 15

Big Injun sand................................... 16

Mauch Chunk formation......................... 17

Unconformity .................................... 17

Pennsylvanian series................................. 18

Pottsville formation .............................. 18

Allegheny and Conemaugh formations................ 19

Mahoning sandstone member (Dunkard sand) ....... $\quad 19$

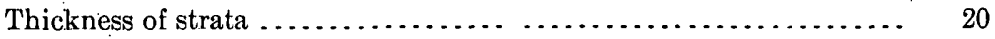

Rocks exposed at the surface................................ 25

Carboniferous system .................................. 26

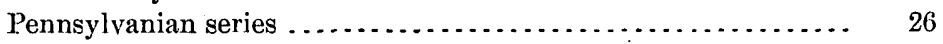

Conemaugh formation $. . \ldots \ldots \ldots \ldots \ldots \ldots \ldots \ldots \ldots \ldots . .26$

Saltsburg sandstone member................... 26

Morgantown sandstone member (Murphy sand) ........ 26

Monongahela formation.......................... $\quad 26$

Pittsburg coal .............................. 27

Pittsburg sandstone member .................... 27

Benwood limestone member ..................... 27

Uniontown sandstone member ................... 27

Waynesburg coal............................ 27

Permian series ..................................... 27

Dunkard group.................................... 27

Washington formation........................ 27 
P • . Page.

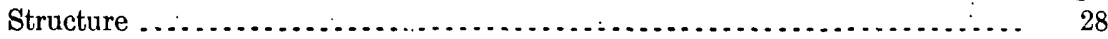

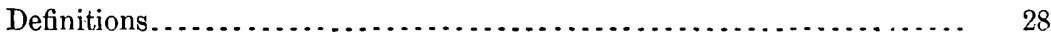

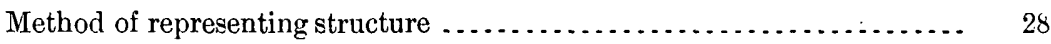

Accuracy of structural contours............................ 29

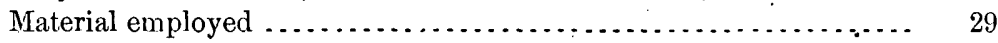

Structural features of the Gordon sand. . . . . . . . . . . . . . . . . . . 31

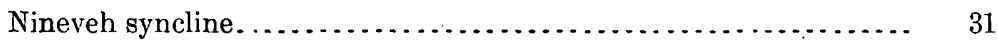

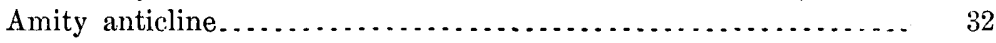

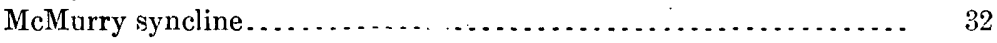

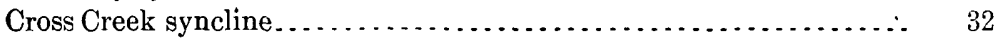

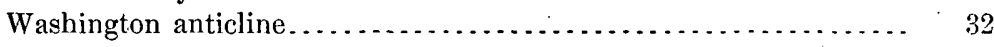

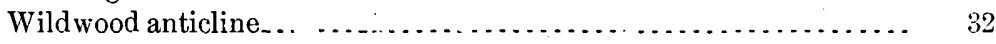

Mount Nebo syncline.................................. 33

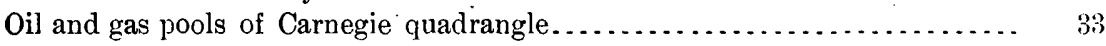

Chartiers Township, Washington County ................... 33

Cecil Township, Washington County .................... 35

Canonsburg oil and gas field . ............................ 35

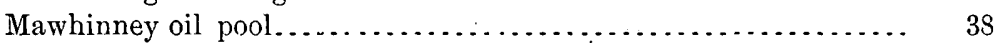

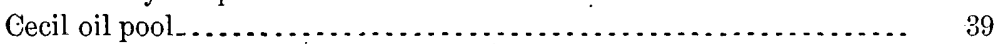

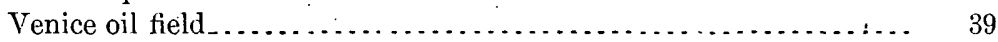

McDonald oil field .................................... 41

North and South Fayette townships, Allegheny County ............ 43

McDonald oil field............................... 43

Hopper oil pool................................... 49

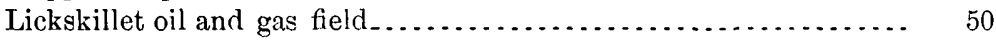

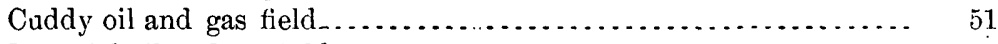

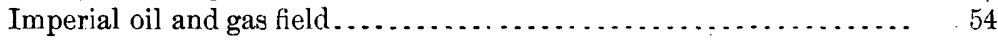

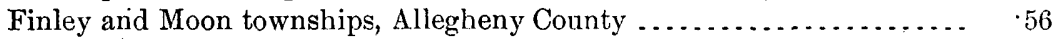

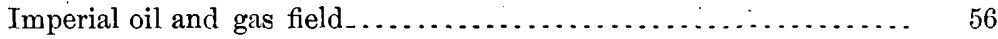

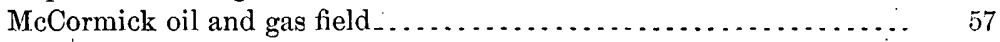

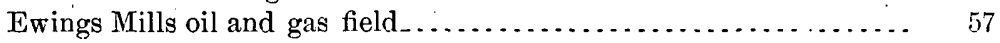

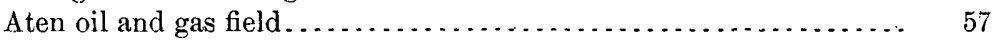

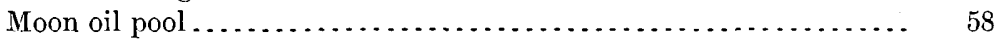

Robinson and Stowe townships, Allegheny County $\ldots \ldots \ldots \ldots \ldots \ldots \ldots \ldots .60$

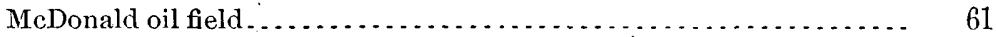

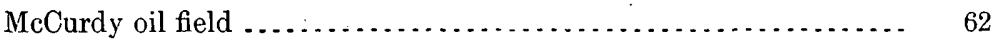

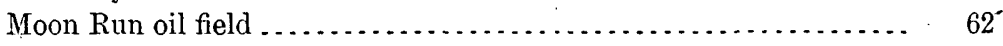

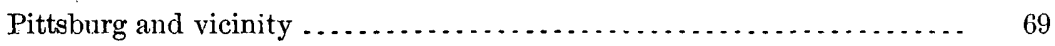

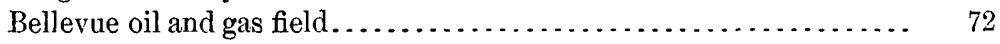

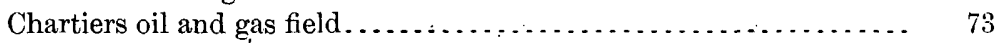

Collier, Scott, and Baldwin townships, Allegheny County .......... 74

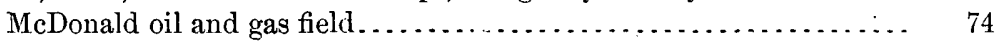

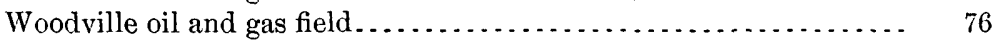

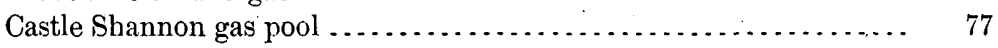

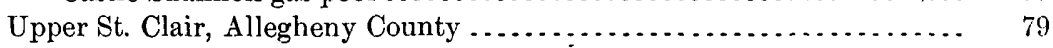

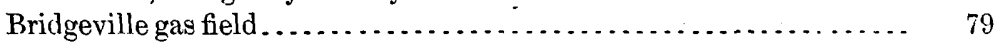

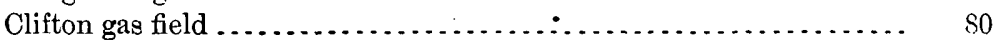

Bethel and Snowden townships, Allegheny County . . . . . . . . . . $\quad 82$

Union Township, Washington County ........................ 84

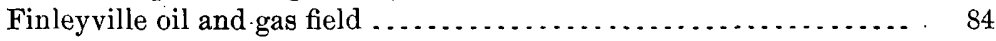

Peters and North Strabane townships, Washington County ............ 85

McMurry oil and gas field .......................... 86 


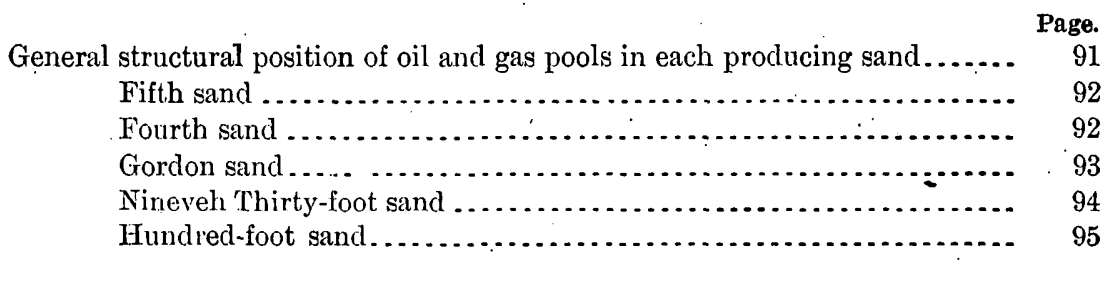

\section{ILLUSTRATIONS.}

PuAte I. Sketch map of western Pennsylvania and portions of New York and

Page.

West Virginia, showing general distribution of the oil and gas fields, so far as known, and location of the area covered by the Carnegie quadrangle............................................. 7

II. Sections of deep wells in the Carnegie quadrangle and vicinity...... 10

III. Sections of deep wells in the Carnegie quadrangle and vicinity...... 10

IV. Sketch map of part of southwestern Pennsylvania, showing general structure by 100 -foot contours on the horizon of the Pittsburg coal and general position of oil and gas pools on this structure...... In pocket.

V. Map of Carnegie quadrangle, showing location of oil and gas pools................................................. In pocket.

Figure 1. Sketch map of the Carnegie quadrangle, showing the distance in feet between the top of the Pittsburg coal and the top of the Gordon sand at numerous points .............................

2. Diagram showing curve of production of oil in the McDonald field from 1890 to June, 1909 , inclusive ...................... • 45 



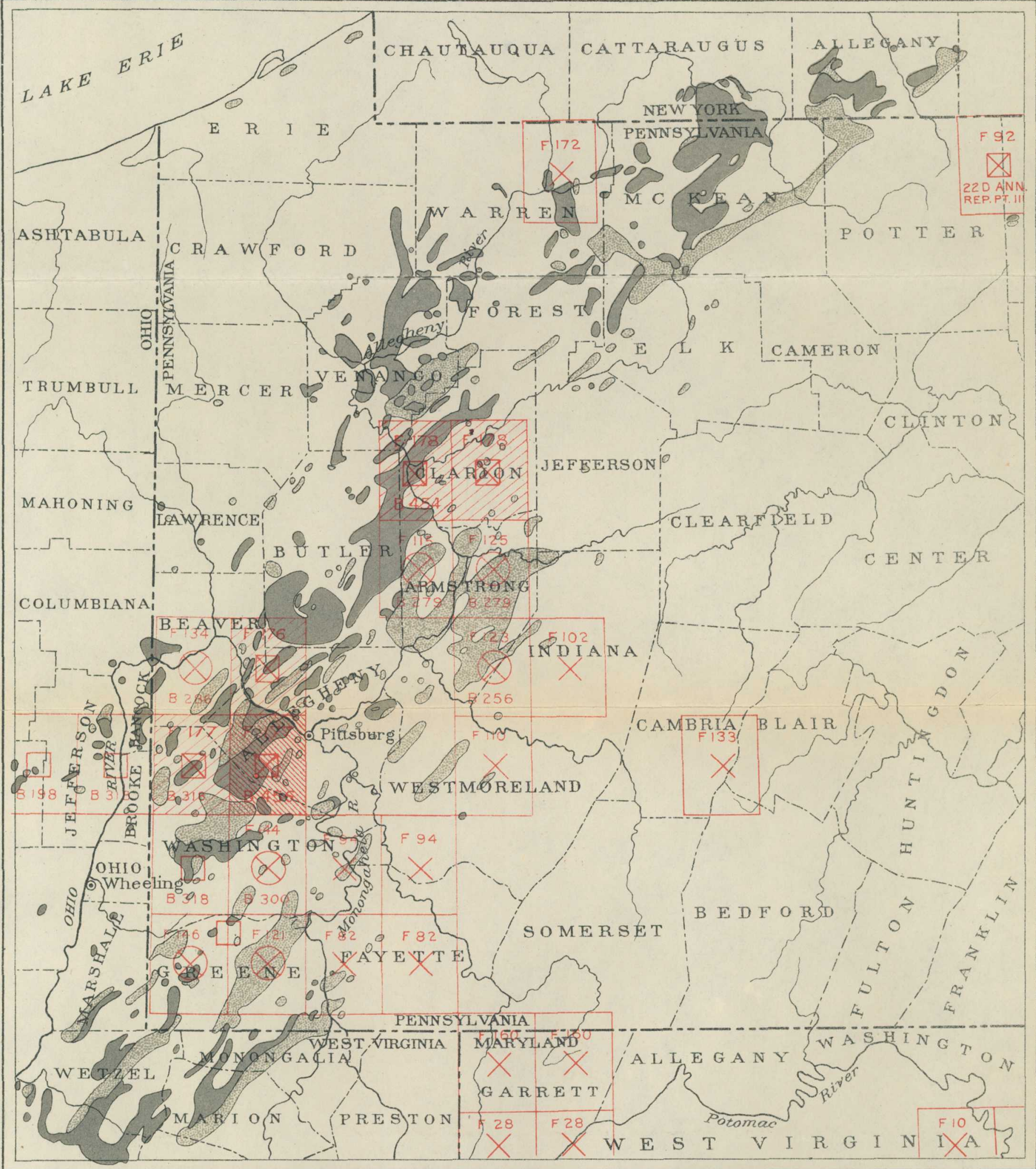

SKETCH MAP OF WESTERN PENNSYLVANIA AND PARTS OF OHIO, WEST VIRGINIA, MARYLAND, AND NEW YORK Showing oil and gas fields, location of quadrangles, and nature of geologic reports published on each

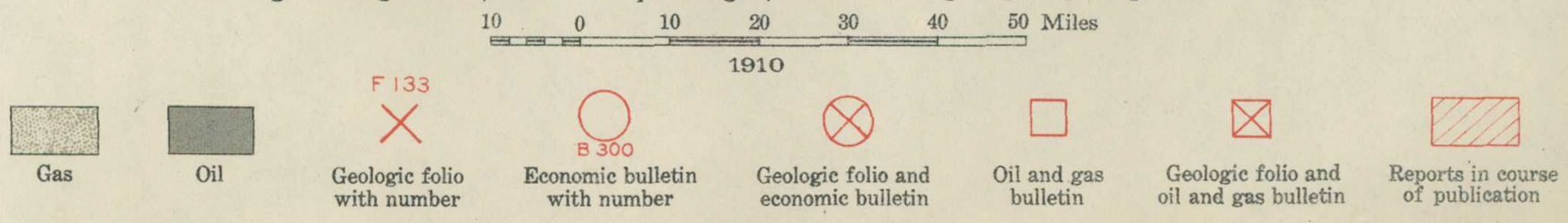




\title{
OIL AND GAS FIELDS OF THE CARNEGIE • QUADRANGLE, PENNSYLVANIA.
}

\author{
By M. J. Munn.
}

\section{INTRODUCTION.}

Field work for a report on the oil and gas of the Carnegie quadrangle was begun by the writer July 23, 1907, and carried on intermittently until December 11 of the same year. The actual time consumed was about three months, the work including less than one month's service of G. L. Hagman as levelman. This statement does not include the time occupied in mapping the outcrop of the Pittsburg coal and in drawing the structural contours-work that was done by G. C. Martin and George F. Peck in connection with geologic work for a folio on this quadrangle.

The writer wishes to acknowledge his indebtedness to hundreds of residents of the region examined for their universally courteous and friendly answers to his inquiries. Special acknowledgment is made to the officers and employees of the large number of oil and gas companies operating in this territory who have furnished hundreds of well records and other data of value.

\section{GEOGRAPHY AND PHYSIOGRAPHY.}

\section{LOCATION.}

The Carnegie quadrangle embraces an area of about 227 square miles in the southwestern part of Pennsylvania, in the vicinity of Pittsburg. It is a quadrilateral, lying between parallels $40^{\circ} 15^{\prime}$ and $40^{\circ} 30^{\prime}$ north latitude and meridians $80^{\circ}$ and $80^{\circ} 15^{\prime}$ west longitude. From Plate $I$ it will be seen that this quadrangle includes portions of Allegheny and Washington counties. It is bounded on the north by the Sewickley quadrangle, of which an oil and gas bulletin is being published by the State of Pennsylvania and a folio by the United States Geological Survey. The geology of the Beaver quadrangle, cornering the Carnegie on the northwest, has been discussed in an economic bulletin (No. 286) and a folio (No. 134) of the United 
States Geological Survey. The oil and gas of the Burgettstown and the Claysville quadrangles, which bound the Carnegie quadrangle on the west and southwest, have been discussed in Bulletin 318 of the Survey, and the geology of the Amity quadrangle, directly south, is presented in Bulletin 300 and Folio 144 of the Survey. The Pittsburg quadrangle, situated east of the Carnegie, has not yet been investigated.

\section{DRAINAGE AND TOPOGRAPHY.}

The Carnegie quadrangle lies wholly within the drainage bdsin of Ohio River. Drainage from more than two-thirds of the quadrangle is through Chartiers Creek directly to Ohio River at McKees Rocks. Moon Run and Mońtour Creek convey considerable water from the northwestern part of the area into Ohio River at the lower end of Neville Island. In the eastern and southeastern parts a number of small streams drain into Monongahela River. As a rule the floopd plains of these streams are very narrow, the adjacent hills being more or less precipitous at their bases but. gradually flattening to well-rounded summits from 100 to 500 feet in height.

\section{STRATIGRAPHY.}

\section{GENERAL CHARACTER OF THE ROCKS.}

The materials composing the rocks of the Carnegie quadrangle were deposited as sediments under water. Each bed is therefore a more or less continuous stratum spread out:over areas relatively. large as compared with its thickness. All beds show variation in thickness and composition from place to place, because of the lack of uniform conditions of deposition. The sediments which formed the clays, shales, or "slates" of the drillers were fine-grained muds washed in by waves and streams. Sandstones came from sands, the grains of which were washed and assorted by waves and currents. The limestones of the quadrangle were probably formed from shells and other calcareous remains of animals that flourished in the seas, bays, and lagoons in which they were laid down. "Red.rock" is a shale composed of finely divided particles of clay containing much iron oxide, and it was probably brought into the body of water in which it was deposited by streams from some old deeply weathered land surface. Coal was formed in swamps. and shallow lagoons from vegetation that grew in or adjacent to them.

For convenience of description, these rocks are divided into two groups-those not exposed at the surface and those that outcrop. Stratigraphically, these groups are discussed by smaller subdivisions or formations, taken in the order of their deposition from oldest to youngest. 


\section{ROCKS NOT EXPOSED AT THE SURFACE.}

\section{SOURCE OF INFORMATION.}

The writer's information concerning the rocks lying below the surface in the Carnegie quadrangle hàs been derived from a study of these rocks by other geologists at points of outcrop and from data furnished by logs of deep wells. Most of the drillings have been made for oil or gas by means of churn drills, a method which does not permit as close measurements or as detailed determinations of the beds encountered as the geologist desires. A large part of the wells of the Carnegie quadrangle were drilled years ago during the great oil excitement attending the development of some of the large fields. Many of these wells were put down by inexperienced drillers and others who, not realizing the geologic value of the material which might have been preserved, kept no record of the rocks penetrated before reaching the oil sands. Most of the records give only the depth of the well or the thickness of the oil or gas bearing bed, and hence are of very little stratigraphic value.

Another difficulty encountered by the geologist in attempting to use detailed records of wells lies in the fact that drillers have not followed a uniform standard of classification for the rocks. Each man called the material he encountered in a well what he thought it might be: If only one driller had operated in a given field, the task of correlating the rocks from his descriptions would be a comparatively easy one. In most fields, however, the drilling has been done by a number of men gathered from various parts of the region, where the geologic conditions are not the same, and each consciously or unconsciously tried to adopt the same nomenclature in the new field that he had been accustomed to in the old. It is therefore probable that if several such drillers had kept independent records of the same well, these would not have been alike in minor details. Again, drillers seldom take more than a passing interest in rocks near the surface in which no oil or gas occurs, and therefore do not usually record the depth and thickness of such beds with care. In a particular area, however, a pair of trained drillers, familiar with the succession of the strata, can drill well after well at points where the structure and the topography greatly change the geologic position of the mouths of the wells and still make records which, when adjusted for structure and topography, will be found as consistent as the nature of the beds penetrated will warrant.

The uncertainty involved in the use of well records for stratigraphic determinations is not diminished by a study of the oil and gas bearing beds at their outcrop, since these beds are so nearly horizontal over wide areas that they appear at the surface only at long distances from where they contain oil or gas pools, and hence they 
may change greatly both in thickness and in composition in that distance. For these reasons the geologist is forced to deal largely in generalities in his studies of the stratigraphy of the rocks not exposed at the surface.

The follcwing table gives a general idea of the geologic age and sequence of the more prominent beds encountered by the drill within the Carnegie quadrangle:

General section of the unexposed rocks of the Carnegie quadrangle:

\begin{tabular}{|c|c|c|c|}
\hline $\begin{array}{l}\text { Sys- } \\
\text { tem. }\end{array}$ & Formation. & Name given by drillers. & Geological name. \\
\hline \multirow[b]{2}{*}{ 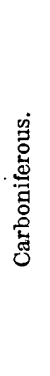 } & Pottsville.... & $\left\{\begin{array}{l}\text { Gas sand } \ldots \ldots \ldots \ldots \ldots \ldots \ldots \ldots \ldots \ldots \ldots \\
\text { Salt or Forty-foot sand } \ldots \ldots \ldots \ldots \ldots \ldots\end{array}\right.$ & $\begin{array}{l}\text { Probably equivalent to Homewood } \\
\text { sandstone member. } \\
\text { Probably equivalent to Connoquenes- } \\
\text { sing sandstone member. }\end{array}$ \\
\hline & Pocono... & 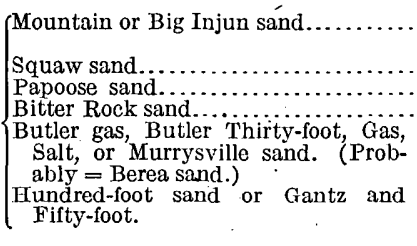 & $\begin{array}{l}\text { Probably equivalent to Burgoon } \\
\text { sandstone member. }\end{array}$ \\
\hline 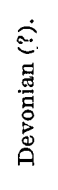 & Catskill (?).. & 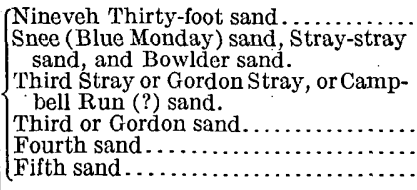 & \\
\hline \multirow{2}{*}{ 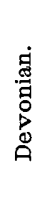 } & Chemung (?)... & 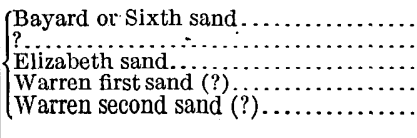 & . \\
\hline & Portage (?).. & & . \\
\hline
\end{tabular}

It will be seen from an examination of the records given below that the terms "Salt" and "Gas" have been applied to a number of different beds. These are most widely applied, however, to the sandstone members of the Pottsville formation, though in the Carnegie quadrangle sandstone beds of the Allegheny formation, overlying the Pottsville, are probably frequently erroneously termed the "gas" and the "salt" sands by drillers. In this paper no attempt will be made to correlate the oil sands of this quadrangle with those of adjacent areas, it being considered best to call attention to Plates II and III, on which are shown the sections of 51 wells plotted to a scale and arranged with reference to the tops of the Pittsburg coal and of the Hundred-foot sand as datum planes. A careful comparison of these sections will give a fair idea of the difficulties encountered in making correlations. This difficulty is seen to be greater when we consider 

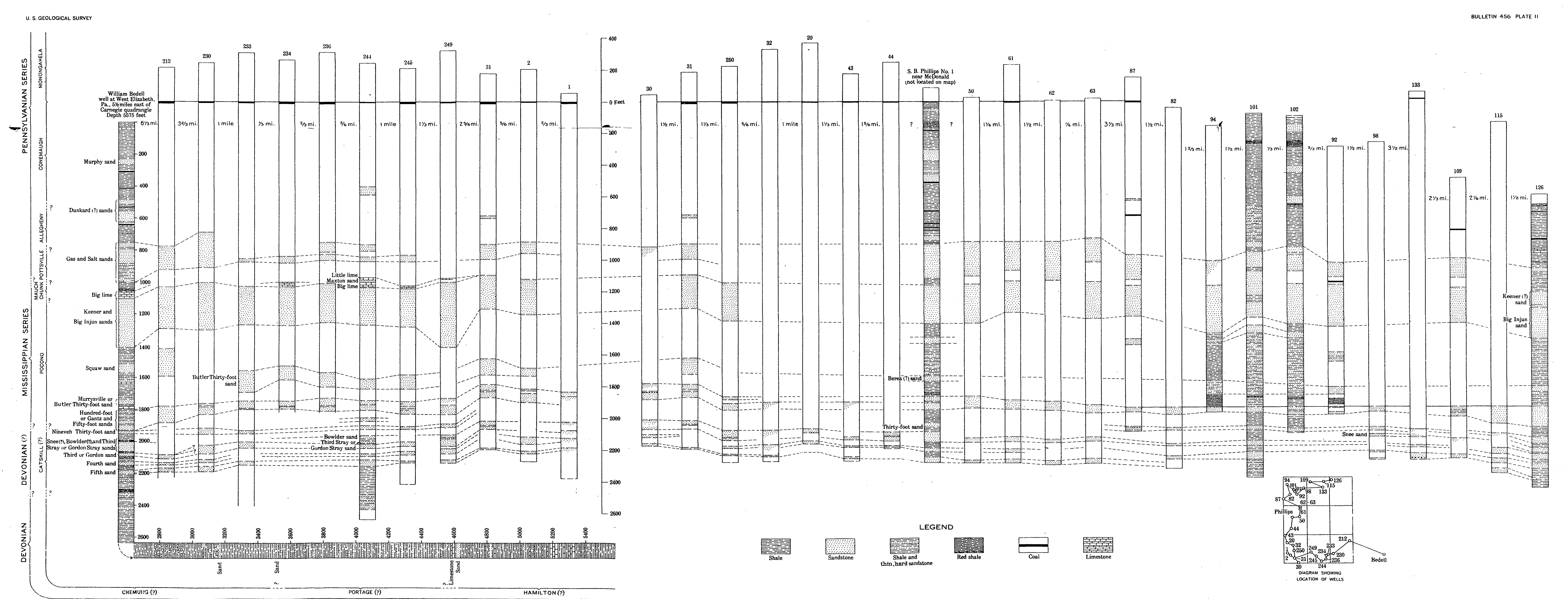

플 들 


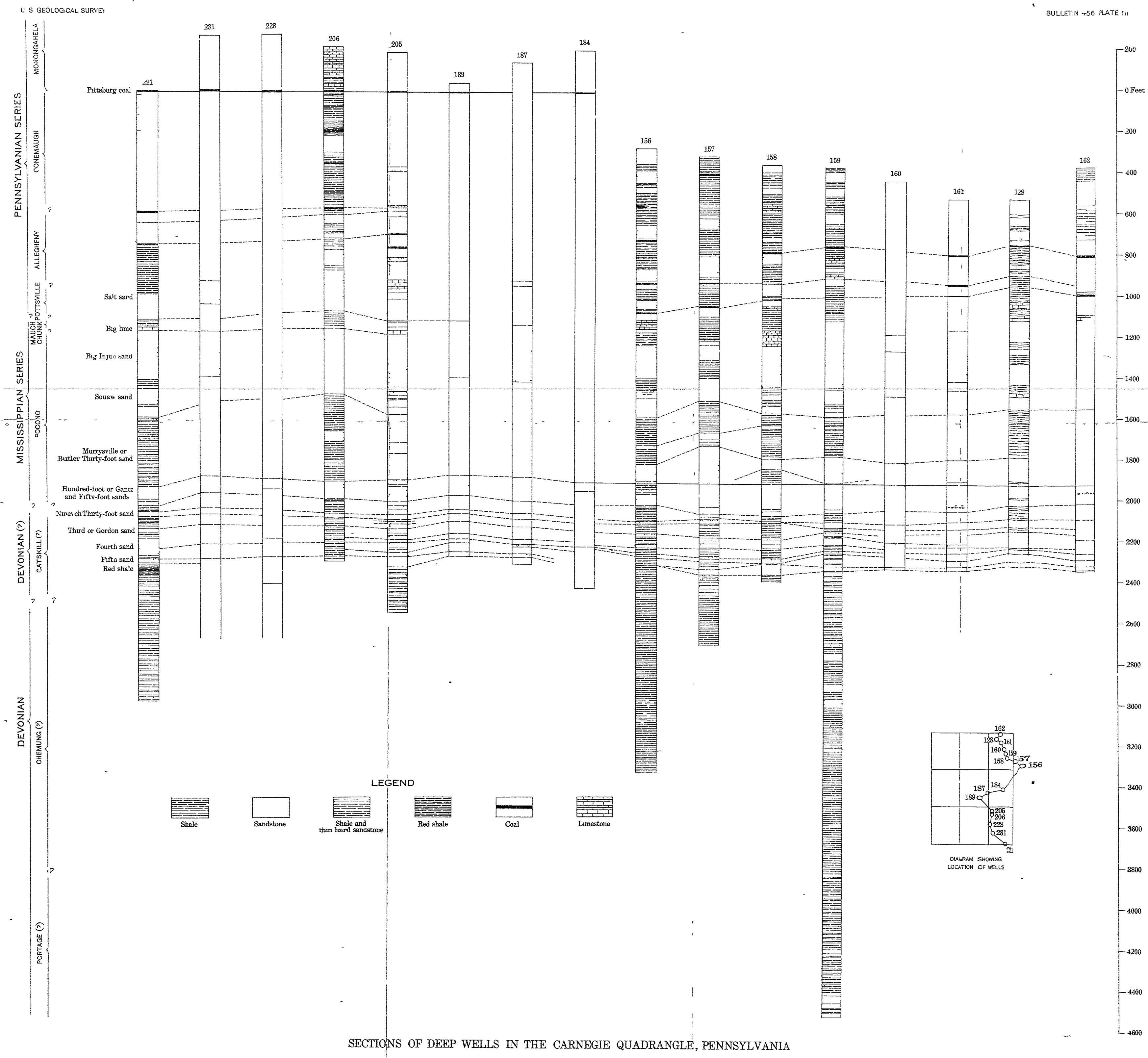


that a very small portion of the horizontal distance covered by a line of sections across a quadrangle is represented by the rock actually passed through by the drill. There is no means of knowing what lithologic changes take place in the beds from well to well.

These plates show two lines of sections of wells across the quadrangle. They have been taken from a large number of records, the selections being made with reference to location of each well and to data shown by the log.

\section{DEVONIAN SYSTEM.}

The lowest rocks of which direct knowledge has been obtained in the vicinity of the Carnegie quadrangle were encountered in a deep well drilled by the Forest Oil Co. on the William Bedell farm, at West Elizabeth. This is the deepest well in Pennsylvania and possibly in - the United States, having a depth of 5,575 feet. It penetrated to a depth of about 5,705 feet below the Pittsburg coal and about 3,500 feet below the Fifth sand, which is the lowest bed producing oil in paying quantities in the quadrangle. A detailed section of this well plotted to a scale of 400 feet to the inch is shown in Plate II.

Within the Carnegie quadrangle a number of wells have been sunk several hundred feet below the lowest producing sand. One of the deepest of these holes is the John A. Beck No. 4 well (No. 159 on map) located in North Side, Pittsburg. This well reached a depth of 4,089 feet and penetrated almost 4,000 feet of beds that do not outcrop on the surface in this quadrangle, and probably about 2,000 feet below the base of the rocks which are generally assigned to the Catskill formation. A complete record of this well as.furnished by the owner, Mr. John A. Beck, follows:

Record of the John A. Beck No. 4 gas well (No. 159), at Pittsburg, Pa.

[Elevation, 732 feet above sea level.]

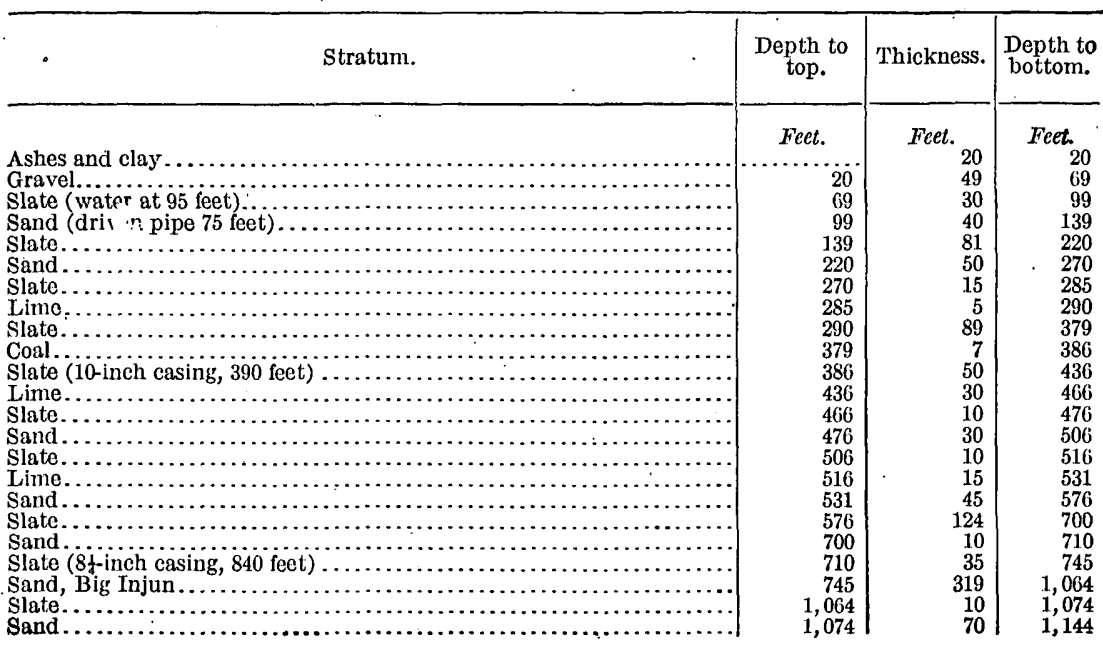


Record of the John A. Beck No. 4 gas well (No. 159), at Pittsburg, Pa.-Continued.

\begin{tabular}{|c|c|c|c|}
\hline$\stackrel{\bullet}{\bullet}$ & $\begin{array}{l}\text { Depth to } \\
\text { top. }\end{array}$ & Thickness. & $\begin{array}{l}\text { Depth to } \\
\text { bottom. }\end{array}$ \\
\hline 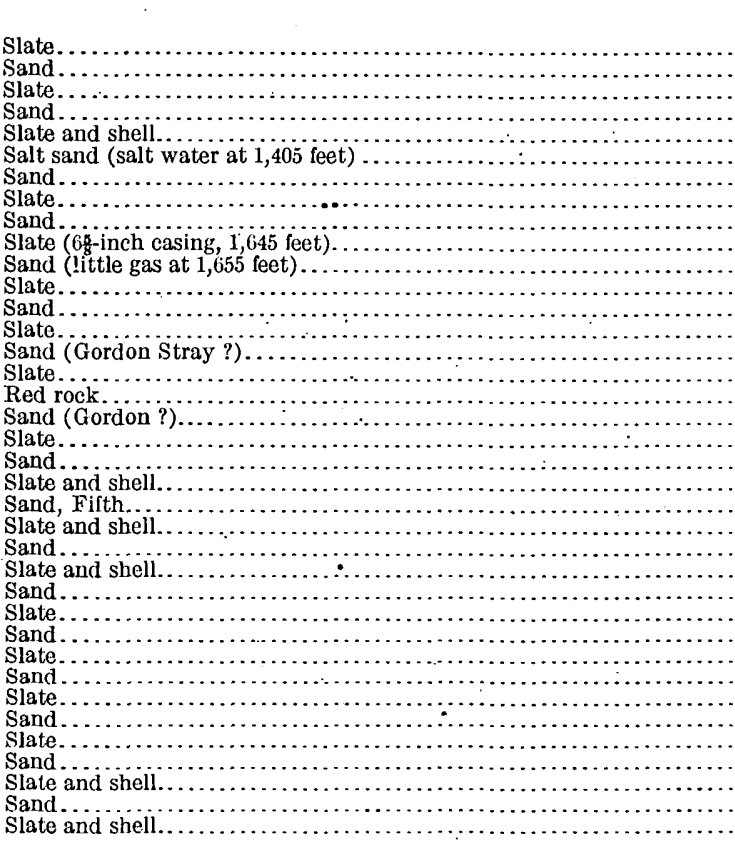 & $\begin{array}{r}\text { Feet. } \\
1,144 \\
1,159 \\
1,179 \\
1,184 \\
1,349 \\
1,395 \\
1,490 \\
1,520 \\
1,530 \\
1,645 \\
1,650 \\
1,660 \\
1,710 \\
1,740 \\
1,770 \\
1,780 \\
1,785 \\
1,790 \\
1,820 \\
1,855 \\
1,865 \\
1,925 \\
1,948 \\
2,030 \\
2,040 \\
2,350 \\
2,380 \\
2,490 \\
2,530 \\
2,565 \\
2,605 \\
2,800 \\
2,820 \\
3,400 \\
3,440 \\
4,000\end{array}$ & $\begin{array}{r}\text { Feet. } \\
15 \\
20 \\
5 \\
20 \\
46 \\
95 \\
30 \\
10 \\
115 \\
5 \\
10 \\
50 \\
30 \\
20 \\
10 \\
5 \\
5 \\
30 \\
35 \\
10 \\
60 \\
23 \\
82 \\
10 \\
310 \\
30 \\
110 \\
40 \\
35 \\
40 \\
195 \\
20 \\
580 \\
40 \\
560 \\
40\end{array}$ & $\begin{array}{c}\text { Feet. } \\
1,159 \\
1,179 \\
1,184 \\
1,204 \\
1,395 \\
1,490 \\
1,520 \\
1,530 \\
1,645 \\
1,650 \\
1,660 \\
1,710 \\
1,740 \\
1,760 \\
1,780 \\
1,785 \\
1,790 \\
1,820 \\
1,855 \\
1,865 \\
1,925 \\
1,948 \\
2,030 \\
2,040 \\
2,350 \\
2,380 \\
2,490 \\
2,530 \\
2,565 \\
2,605 \\
2,800 \\
2,820 \\
3,400 \\
3,440 \\
4,000 \\
4,040 \\
4,0891 \\
\end{array}$ \\
\hline
\end{tabular}

The lower.700 feet of sandstones and "slate and shells" encountered in this well probably are of Portage age. Above them the 800 feet of shale and also about 500 feet of overlying "slate and shells" probably belong to the Chemung formation. No line of demarcation between these formations can be clearly established, since in regions where they do not outcrop paleontologic evidence is not available. The writer has tentatively considered the top of the Chemung to be the bottom of the lowest "red rock" mentioned in the records, which is sometimes found about 100 feet below the Fifth sand. However, the variability from place to place of these beds of red shale precludes any definite establishment of this boundary from well records alone.

Within the Carnegie quadrangle no oil or gas has been found in the rocks tentatively assigned to the Chemung formation, with the possible exception of a small quantity of gas in the Bayard or Sixth sand, at or near the supposed top of the formation. Farther north in Pennsylvania the Tiona, the Speechley, and the Warren sands, which are assigned to this formation, lie from about 400 to 800 feet below the Fifth sand of the Venango group of oil sands. In the Carnegie quadrangle a few thin beds of sandstone are frequently found at what seems to be about the horizons of the Warren, Speechley, 
and 'Tiona sands, but there is no means at hand for making definite correlations. Indications of oil and gas have been found in these sand stones at a few places in the quadrangle, but, so far as the writer could learn, in no place is the production in quantities sufficient to justify development.

\section{DEVONIAN (?) SYSTEM.}

CATSKILL (?) FORMATION.

In the Carnegie quadrangle the rocks tentatively assigned to the .Catskill formation comprise about 400 feet of strata containing red shale, and extend from the base of the lowest "red rock," about 100 feet below the Fifth sand, upward to the top of the "red rock" underlying the Hundred-foot sand. In addition to the characteristic red shale, which forms a small percentage of the entire thickness, these rocks are composed of variegated shale and thin reddish or white sandstones. These sandstones and the Hundred-foot sand immediately overlying the beds assigned to the Catskill comprise most of the Venango oil-sand group and have been found to contain almost all of the oil and by far the largest portion of the gas of southwestern Pennsylvania. The economic importance of these rocks renders necessary a somewhat more detailed discussion of the stratigraphy.

Fifth sand.-The horizon of the Fifth sand is represented by a white or gray lenticular bed of sandstone, lying about 100 feet above the base of the formation and about 2,200 to 2,250 feet below the Pittsburg coal. (See well sections, Pls. II and III.) It is as much as 35 or 40 feet in thickness, but usually ranges between 15 and 30 feet. It is composed of fairly clean quartz sand, which changes from fine to coarse texture and even becomes conglomeratic very abruptly in both horizontal and vertical directions. In general a cross section of this sandstone shows several feet of hard medium to fine grained sand, embedded in which are thin lenses of coarse white sand and small quartz pebbles. These lenses are usually from 1 to 8 and, rarely, 20 feet in thickness, and constitute the "pays" or pay streaks in which the accumulations of oil and gas occur. The Fifth sand, which in this district is sometimes locally known as the McDonald sand, appears to be represented by a sandy phase of the formation at all points within the quadrangle, but it is sometimes marked by only a few feet of thin hard layers of sandstone interbedded with shale, which are designated by drillers as "slate and shells." Overlying this sand are from 40 to 60 feet of soft dark-greenish or red shales up to the base of the Fourth sand.

Fourth sand.-The sandstone called the Fourth sand is very. similar in color, texture, and thickness to the Fifth sand. It is, however, somewhat more variable in occurrence, probably attains greater local thickness, and generally contains thinner and fewer pebbly pay streaks than the Fifth. This sand is separated from the 
Third or Gordon sand above by from 50 to 75 feet of soft generally reddish or geenish shales, which frequently include thin beds of. "red rock."

Third or Gordon sand and Third Stray or Gordon Stray sand.These two sands are usually separated by a shale "break," which reaches in places a maximum thickness of 25 feet. - In southwestern Pennsylvania they are known as the Gordon and the Gordon Stray sands, the name having been derived from a farm near Washington, Pa., where oil in the Gordon sand was first discovered in the county. Farther north, in Beaver, Butler, and Armstrong counties, these beds are known as the Third and the Third Stray sands. Over much of the Carnegie quadrangle they are so closely associated that no distinct shale "break" between them can be detected, and they have all the appearance of a single sand; at other places the shale "break" is as much as 40 feet in thickness, and the beds are distinct sandstones. Between these two extremes all gradations occur. When merged into a single sandstone these two beds have a thickness of 50 to 75 feet. When separate each is sometimes reduced to only a few feet of "slate and shells," though they usually range from 15 to 25 feet. The Third or Gordon sand, which is the lower, is usually composed of fine to medium grained quartz sand, white or gray in color, and, like all the sands of the Venango oil group, contains soft pebbly pay streaks of coarse sand, from which the oil and gas are produced. The Third Stray or Gordon Stray sand is usually gray or reddish and sometimes even dark in color. It appears to change rapidly in thičkness from place to place and to contain fewer pay streaks than the Gordon.

Bowlder (?) sand.-An interval of 40 to 80 feet separates the Gordon Stray sand from the Nineveh. Thirty-foot sand above. Within the Carnegie quadrangle this interval is usually filled with shale and "red rock," in which is embedded here and there a thin sandstone lens. This sand is probably equivalent to the Bowlder sand of the oil region farther north, but may more nearly correspond to the Snee (Blue Monday) sand of northern Allegheny County, which lies above the Bowlder sand and under the Nineveh Thirtyfoot sand, or to the Stray-stray sand of the southern part of Washington County. This sand appears to be best developed in the northern part of the quadrangle, where it is from 5 to 20 feet thick and occurs from 20 to 40 feet above the Gordon Stray.

In most of the Appalachian region drillers find difficulty in distinguishing the Bowlder sand from the Gordon Stray sand below and from the Snee sand above.

Nineveh Thirty-foot sand.-The Nineveh Thirty-foot sand is the uppermost sandstone of what is considered to be the Catskill formation in this quadrangle. It lies from 90 to about 110 feet above the 
Third or Gordon sand and about 50 to 110 feet below the base of the Hundred-foot sand. It is usually a hard, fine-grained, gray sandstone, from 10 to 30 feet thick, with a thin coarse sand and pebbly pay streak near. the middle. The interval between the Nineveh Thirty-foot sand, and the Hundred-foot sand is filled with, soft green and red shales. The uppermost bed of "red rock" usually occurs only a few feet below the bottom of the Hundred-foot sand. This bed marks the upper limit of the deposits which are believed to represent the Catskill formation, the Hundred-foot sand above apparently belonging to the Pocono formation, ${ }^{a}$ though a thick bed of red shale is frequently found overlying it.

\section{CARBONIFEROUS SYSTEM.}

\section{MISSISSIPPIAN SERIES.}

POCONO FORMATION.

In the Carnegie quadrangle the Pocono formation is about 850 feet thick. The lower and the upper portions consist of massive sandstone, inclosing toward the center from 300 to 450 or more feet of soft gray, red, and black shales.

Hundred-foot sand.-The Hundred-foot sand, which is regarded as the basal member of the Pocono formation, is one of the most persistent and widespread sands of the region. 'It is usually made up of two members; known in this quadrangle as the Fifty-foot and the Gantz sands. These, together with their intervening "break" of shale, range from 50 to about 115 feet in thickness. The lower or Fifty-foot sand seems to be much more persistent than the Gantz, which is lenticular in the northern and central parts of the quadrangle but thickens and becomes more uniform toward the south.

Both members of the Hundred-foot sand are typical oil sands, white or gray in color, of medium grain and hardness, and containing here and there lenses of coarse, pebbly sand which are sometimes filled with oil, gas, or salt water. Above the Hundred-foot sand is an interval of from 20 to more than 100 feet which is usually filled with red and green shales. The "red rock" at this horizon is one of the most persistent within the quadrangle. Its thickness in some wells is 90 feet or more, and it forms a characteristic geologic marker for drillers over much of this area.

Murrysville or Butler Thirty-foot sand.-Upon the "red rock" generally lies a lenticular sandstone that is in places as much as 150 feet thick and is usually considered to be the equivalent of the Murrysville Gas sand of Westmoreland County, farther east. In Butler 
and Armstrong counties a gas-bearing sand which seems to be equivalent to this bed is generally known as the Butler Gas sand, Butler Thirty-foot; or Thirty-foot sand. Farther west, in Washington and Beaver counties, a sand at what seems to be this horizon is generally designated as the Berea sand, and is considered by drillers to be equivalent to the Berea sandstone of northern Ohio. Charles Butts, ${ }^{a}$ who has recently published some interesting facts relative to the correlation of these beds, considers the Berea sandstone of Ohio to be equivalent to the Hundred-foot sand of northern Pennsylvania, and therefore older than the Murrysville or Butler Thirty-foot sand of the Carnegie quadrangle. With the data now available it seems impossible to define clearly the position of the true Berea sandstone of Ohio in the geologic column of southwestern Pennsylvania. The writer does not question the correlation by Butts for northern Pennsylvania, but in tracing the Hundred-foot sand southward to Washington County from Clarion County there is evidence that this sand is broken by persistent shale beds into a group of sandstones embracing the Fifty-foot, the Gantz, and the Murrysville or Butler Thirty-foot sands, and that the last sand is equivalent to the thin oil-bearing sand of southeastern Ohio, which is widely known as the Berea sand. If this is true, the Berea sand of southeastern Ohio is equivalent to only the upper portion of the Berea of northern Ohio.

Between the top of the Murrysville or Butler Thirty-foot sand and the bottom of the Big Injun sand are from 300 to 450 feet of soft dark or gray sandy shale, in which one or more thin beds of sandstone are found in most of the wells drilled through this formation. These sands are very irregular in occurrence, however, and appear to occupy no definite horizon. In a number of wells the whole interval is reported as shale; in others it is made up of thin alternating beds of shale and hard sandsitone. In the Carnegie quadrangle these sands in places contain more or less salt water but little or no oil or gas. The lower of the two more persistent beds is called by some drillers the Bitter Rock sand. The upper bed is generally called the Squaw sand, though this name is also applied to a sandstone near the base of the Big Injun.

Big Injun sand.-Throughout the Carnegie quadrangle this great sandstone, ranging from about 200 to 400 feet in thickness, is easily recognized by oil drillers. It is usually a very hard, medium-grained white or gray sandstone, generally unbroken by shale partings, but locally divided into two or more sands by thin "breaks" of dark shale, rarely more than 10 or 20 feet in thickness: This sandstone 
contains in many places large quantities of salt water and in a few places pools of gas, both the water and the gas being confined to soft, porous lenses only a few feet thick and of small extent.

MAUCH CHUNK FORMATION.

In the southern part of the Carnegie quadrangle drillers frequently report from 5 to 50 feet of limestone which is usually designated as the Big lime and which is doubtless equivalent to the Greenbrier limestone member of the Mauch Chunk of the Appalachian Basin, farther south. In a number of places this limestone is overlain by soft shale from 10 to 100 feet. in thickness. A few feet of the lower part of this shale has the characteristic red color of the Mauch Chunk, and it seems probable that this entire shale mass belongs to. that formation. Traced northward, these beds pinch out near the middle of the quadrangle, but small isolated outliers may perhaps be found. The disappearance of these beds toward the north is doubtless due to a great unconformity at the top of the Mississippian series.

\section{UNCONFORMITY.}

It seems very probable that the Greenbrier limestone member and the overlying shale of the Mauch Chunk formation were once deposited to an unknown thickness over the entire quadrangle. Subsequently this area was elevated and became dry land, the greatest movement being at the north. The land was exposed to erosion long enough for the streams to remove all of these beds from an indefinite area lying farther north and west and to return this material to the adjacent sea bottom. The thin remnants of the shale of the Mauch Chunk formation and its Greenbrier limestone member in the Carnegie quadrangle are all that remained uneroded when the land was again submerged and the deposition of the Pottsville formation began. This erosion interval was of shorter duration toward the southeast, and hence in that direction the Mauch Chunk thickens. It should be remembered, however, that all points where the Greenbrier limestone member is covered by the red shale of the Mauch Chunk, it could not have been subjected to erosion, and is therefore in its full thickness. The minimum original thickness of the limestone in this quadrangle is only a few feet as against several hundred or a thousand feet in West Virginia, Kentucky, and Tennessee. It is therefore reasonable to suppose that this bed never extended much farther north than the Carnegie quadrangle.

83448 ${ }^{\circ}-$ Bull. $456-11 \div 2$ 


\section{PENNSYLVANIAN SERIES.}

POTTSVILLE FORMATION.

Geologic history.-At the end of Mauch Chunk time a broad uplift in western Pennsylvania and adjacent parts of New York, Ohio, and West Virginia brought the recently deposited Mauch Chunk formation above sea level and exposed it to erosion. This erosion continued longest in northwestern Pennsylvania and New York, where not only the Mauch Chunk formation but the Burgoon sandstone member of the Pocono formation and the entire shale underlying it were removed and redeposited in adjacent sea as Pottsville beds. Deposition of early Pottsville beds probably began at the northwest, and as subsequent subsidence took place the shore line encroached upon the land lying to the southeast and successively younger beds were deposited unconformably upon the old land surface. This period of subsidence was not continuous, but was interrupted by at least one period during which coal-forming vegetation grew in portions of a large region northwest of this quadrangle, and the Sharon conglomerate member and the Sharon coal were then formed. During this period of early Pottsville deposition probably no beds were laid down in the area embraced by the Carnegie quadrangle. ${ }^{a}$ When subsidence finally began and the sea encroached over this territory a coarse sandstone, probably the Connoquenessing sandstone member, was spread out over the sea bottom from the advancing shore line, and therefore lies unconformably upon the remnants of the Mauch Chunk formation.

Members.-In most of northwestern Pennsylvania the Pottsville consists of (1) the Homewood sandstone member at the top, (2) the Mercer shale member (consisting of shales, coals, limestones, and fire clay), (3) the Connoquenessing sandstone member and Quakerstown coal, and (4) the Sharon conglomerate member and coal at the base, the whole having a total thickness of probably less than 400 feet. In this quadrangle the different divisions of the formation are indistinguishable in well records, the sections showing such abrupt changes from place to place that no definite correlation of the beds overlying the Big Injun sand can be made. In fact, an examination of the well sections (Pls. II and III) shows that the Big Injun sand itself can not always be separated with certainty from the sandstones of the Pottsville formation above, since in areas where the upper shale of the Mauch Chunk and the Greenbrier limestone member were removed by erosion the basal sandstone of the Pottsville appears to rest directly upon the eroded surface of the Big Injun sand. 
Salt sand.-As shown by the well sections (Pls. II ana III), the Salt sand of the drillers constitutes from less than 1.00 to more than 300 feet of sandstone overlying the Mauch Chunk in the southern part of the quadrangle and resting. directly upon the Big Injun sand farther north: This is a coarse, pebbly gray to reddish quartz sand, which, like the Big Injun, frequently carries large quantities of salt water and occasionally small pools of gas. In many places this appears to be separated into two beds with a shale "break" which reaches a maximum thickness of as much as 50 feet. In such cases the upper bed is frequently designated by drillers as the Gas sand. The extreme variability of the beds above the unconformity renders any correlation from well records very doubtful, and it is possible that the so-called Gas sand may in reality be equivalent to the Homewood sandstone member at the top of the Pottsville formation. The uncertainty of this correlation is augmented by the poor measurements made of these beds by drillers:

ALLEGHENY AND CONEMAUGH FORMATIONS.

The Allegheny and Conemaugh formations, which constitutes the upper 500 to 800 feet of the unexposed rocks of the Carnegie quadrangle, contain no oil or gas bearing beds of importance, and hence have received scant notice from drillers. In this region the Allegheny formation consists of about 300 feet of shales, coals, clays, limestones, and thin sandstones, extending from the top of the Gas sand up to the top of the Upper Freeport coal. The Conemaugh has a total thickness of 500 to 600 feet, and includes all rocks between the top of the Upper Freeport coal and the bottom of the Pittsburg coal bed. The upper 400 or 500 feet of this formation are exposed in outcrop along the Ohio River and in some of the deeper valleys, and it is therefore discussed under "Rocks exposed at the surface."

Mahoning sandstone member (Dunkard sand).-The unexposed portion of the Conemaugh formation consists principally of sandstone and sandy shale, including the Mahoning sandstone at the base, which ranges from 30 to more than 100 feet in thickness. This sandstone is usually separated into two members by a clay and shale "break," ranging up to 30 feet or more in thickness. The two sandstones are generally termed the Big and the Little Dunkard sands. They usually contain fresh or salt water in considerable quantities, and in a few places in the quadrangle furnish small "pockets" of gas.

In the extreme southwestern part of Pennsylvania and adjacent portions of West Virginia these sands furnish a number of good oil and gas pools at points where the sands are between 1,000 and 2,000 feet below the surface. The other beds of these formations are of little or no economic interest to oil and gas producers. 


\section{THICKNESS AND CHARACTER OF UNEXPOSED STRATA AS SHOWN BY LOGS OF DEEP W WLLLS.}

The following detailed records show the general nature of the material from which stratigraphic studies of the unexposed rocks of this quadrangle are made. Sections of some of these wells are also shown on Plates I and II.

Record of Samuel Conners well No. 3 (No. 6 on map), Cecil Township, Washington County, $P a$.

[Owned by Manufacturers' Light \& Heat Co. Elevation of well mouth above sea level, 1,012 feet.]

\begin{tabular}{l} 
Stratum. \\
\hline
\end{tabular}

Record of , Jones \& Laughlin well No. 1 (No. 156 on map), Pittsburg, Allegheny County, Pa.

[Owned by American Iron \& Steel Co. Elevation of well mouth above sea level, $7 \dot{3} 5$ feet. Second Geol. Survey Pennsylvania, vol. I3; p. 730.$]$

\begin{tabular}{|c|c|c|c|}
\hline Stratum. & $\begin{array}{l}\text { Depth to } \\
\text { top. }\end{array}$ & Thickness. & $\begin{array}{l}\text { Depth to } \\
\text { bottom. }\end{array}$ \\
\hline Sandy slate and shells. . & Feet. ${ }_{80}$ & Fęet. 15 & Feet. ${ }_{95}$ \\
\hline 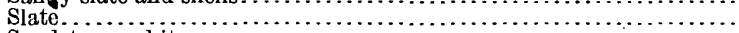 & 95 & 15 & 110 \\
\hline 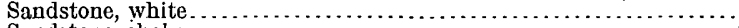 & 110 & 60 & 170 \\
\hline 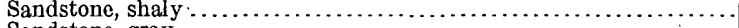 & 170 & 15 & 185 \\
\hline 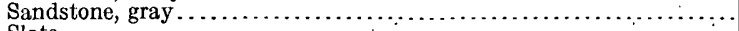 & 185 & 33 & 218 \\
\hline $\begin{array}{l}\text { Slate } \\
\text { Sandy slate and shale, very fine, mica, some gray limestone and coal, }\end{array}$ & 218 & 12 & 230 \\
\hline $\begin{array}{l}\text { Sandy slate and shale, very fine, mica, some gray limestone and coal, } \\
\text { slate near top, trace of lime all through } \ldots \ldots \ldots \ldots \ldots \ldots \ldots \ldots \ldots\end{array}$ & 230 & 58 & 288 \\
\hline 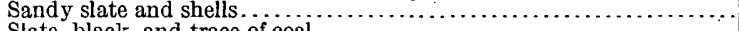 & 288 & 27 & 315 \\
\hline black, and trace of coal. $\ldots \ldots \ldots \ldots \ldots \ldots \ldots \ldots \ldots$ & 315 & 20 & 335 \\
\hline Sandy slate and shells, faint trace of lime $\ldots \ldots \ldots \ldots$ & 335 & 35 & 370 \\
\hline 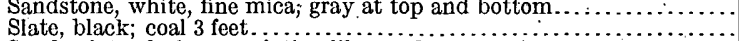 & $370^{\circ}$ & 70 & 440 \\
\hline slate, dark, granulating like sand $\ldots \ldots \ldots$ & $\begin{array}{l}440 \\
450\end{array}$ & & $\begin{array}{l}450 \\
505\end{array}$ \\
\hline Sandy slate and brown and white shells, trace of coal.. & 505 & 15 & \\
\hline Sandy slate, gray, fine, mica; much lime............ & 520 & & 540 \\
\hline 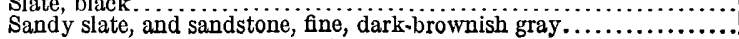 & $\begin{array}{l}540 \\
585\end{array}$ & $\begin{array}{l}45 \\
10\end{array}$ & $\begin{array}{r}585 \\
. \quad 595\end{array}$ \\
\hline
\end{tabular}


Record of Jones \& Laughlin well No. 1 (No: 156 on map), Pittsburg, Allegheny County, Pa.-Continued.

\begin{tabular}{|c|c|c|c|}
\hline Stratum. & $\begin{array}{l}\text { Depth to } \\
\text { top. }\end{array}$ & Thickness. & $\begin{array}{l}\text { Depth to } \\
\text { bottom. }\end{array}$ \\
\hline & & Feet. & Feet. \\
\hline 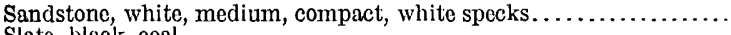 & 595 & 50 & \\
\hline & 645 & 10 & \\
\hline 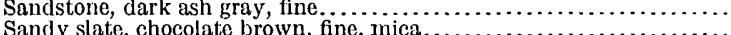 & 655 & 25 & 680 \\
\hline $\begin{array}{l}\text { Sandy slate, chocolate brown, fine, mica. } \\
\text { Slate, dark with gray shells. }\end{array}$ & 680 & 30 & 710 \\
\hline $\begin{array}{l}\text { Slate, dark with gray shells. } \ldots \ldots \ldots \ldots \\
\text { Sandstone, white, medium compact. }\end{array}$ & & $\begin{array}{l}20 \\
40\end{array}$ & $\begin{array}{l}730 \\
770\end{array}$ \\
\hline Slate, black, with some coal. ........ & $\begin{array}{l}730 \\
770\end{array}$ & $\begin{array}{l}40 \\
20\end{array}$ & 790 \\
\hline (?) Specimens omitted.......... & 790 & 35 & 825 \\
\hline Siliccons limestone. ............... & 825 & 20 & 845 \\
\hline Siliccous limestone, like bluish sandy shale $\ldots \ldots \ldots \ldots \ldots \ldots \ldots \ldots$ & 845 & 8 & 853 \\
\hline Siliccous limestone, like gray light sand. $\ldots \ldots \ldots \ldots \ldots \ldots \ldots \ldots \ldots$ & 853 & 27 & \\
\hline 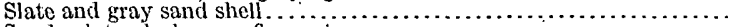 & 880 & 30 & 910 \\
\hline Sandy slate, dark gray, fine, mica $\ldots \ldots \ldots \ldots \ldots \ldots \ldots$ & 910 & 35 & 945 \\
\hline Sandstone, white, medium, compact; some dark slate at 1,045 and 1,080 & & & \\
\hline 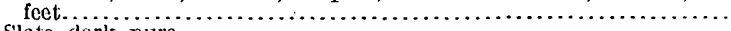 & 945 & 160 & 1,105 \\
\hline Slate, dark, purc... & 1,105 & 60 & 1,165 \\
\hline White sand and dark sandy slate; "salt and pepper rock" ...... & 1,165 & 35 & 1,200 \\
\hline 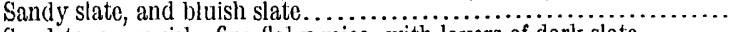 & 1,200 & 20 & 1,220 \\
\hline Sandstone, grayish; fine flaky mica, with layers of dark slate...... & 1,275 & 20 & 1,295 \\
\hline Slate, a little sandy 20 fect; common 45 feet; a little sandy 65 feet...... & 1,295 & 130 & 1,425 \\
\hline Sandstone, gray, fine; some lime; "Gas sand" (Berea) ............. & 1,425 & & 1,450 \\
\hline Slate, common; little sandy top and bottom $\ldots \ldots \ldots \ldots \ldots \ldots$ & 1,450 & 75 & 1,525 \\
\hline $\begin{array}{l}\text { Sandstone, white, top fine; center and bottom quite coarse (Hundred- } \\
\text { foot) } \ldots \ldots \ldots \ldots \ldots \ldots \ldots \ldots \ldots \ldots \ldots \ldots \ldots \ldots \ldots \ldots \ldots\end{array}$ & 1,525 & 93 & 1,618 \\
\hline 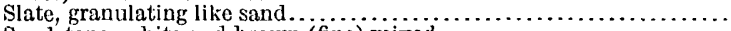 & 1,618 & 7 & 1,625 \\
\hline Sandstone, white and brown (fine) $\mathrm{mi}$ & 1,625 & 10 & 1,635 \\
\hline Slate and shells, dark............... & 1,635 & 8 & 1,643 \\
\hline $\begin{array}{l}\text { Sandstone, white; top, gray and mixed with sandy slate; bottom, } \\
\text { white, little slate; pebble shell at } 1,650 \text { feet. . . . . . . . . . . . . . }\end{array}$ & 1,643 & 25 & 1,608 \\
\hline Slate and sandy shells & 1,668 & 7 & 1,675 \\
\hline white, medium; pebble shell at 1,705 feet. . . . . . . . & 1,675 & 45 & 1,720 \\
\hline 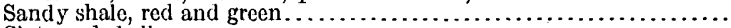 & 1,720 & 20 & 1,740 \\
\hline shells................ & 1,740 & 15 & 1,755 \\
\hline (1) & 1,755 & 43 & 1,798 \\
\hline pebbly, good flow of gas ( & 1,798 & 7 & 1 , \\
\hline Slate, black, iron pyrites (probably some shells at top) $\ldots . \ldots \ldots$. & 1,805 & 15 & \\
\hline Slate, dark, with greenish-gray shells and streaks of red......... & 1,820 & 13 & 1,833 \\
\hline 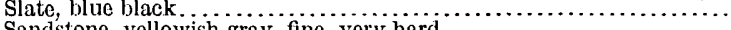 & 1,833 & 27 & 1,860 \\
\hline 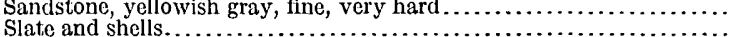 & 1,860 & 8 & 1,868 \\
\hline 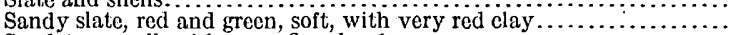 & $\begin{array}{l}1,808 \\
1,880\end{array}$ & 10 & $\begin{array}{l}1,880 \\
1,890\end{array}$ \\
\hline fine, hard. & 1,890 & 10 & 1,900 \\
\hline ty. . . . . . & 1,900 & 3 & 1,003 \\
\hline Si & 1,903 & 12 & 1,915 \\
\hline lowish gray, medium & 1,915 & 7 & 1,922 \\
\hline Sla & 1,922 & 24 & 1,946 \\
\hline & 1,946 & 8 & 1,95 \\
\hline harc ${ }^{2}$ & 1,8 & & \\
\hline & 1,9 & 3 & 1, \\
\hline ish gray with & 1,959 & 3 & 1,962 \\
\hline shells: & 1,962 & 6 & 1,968 \\
\hline & 1,968 & 11 & 1,979 \\
\hline Sandstone, white, fine, mica, flaky, l & 1,979 & 7 & 1,986 \\
\hline imon.................. & & & \\
\hline & 2,0 & & \\
\hline Sandstone, white, very fine ar & 2,025 & & 2,034 \\
\hline common.............. & 2,034 & 132 & 2,166 \\
\hline reddish layer & 66 & 77 & 243 \\
\hline & & 148 & \\
\hline & & 90 & \\
\hline on (fossils at 2,485 feet).. & 2,481 & 136 & 2,617 \\
\hline stone and slate, brownish gray, n & 2,617 & 4 & 2,621 \\
\hline with 2 -foot fossll band at 2,660 fo & 2,621 & 44 & 2,665 \\
\hline tes and some fossils... & & 246 & 911 \\
\hline te, some fossil ban & 2,911 & & \\
\hline
\end{tabular}

Some gas struck at 1,798 feet; large flow at 1,804 feet. This well is located on the east side of Twentysixth Street, near the river, twenty-fifth ward, Pittsburg. South Side. 
Record of N. Fife well No. 1 (No. 205), Upper St. Clair Township, Allegheny County, Pa. [Owned by Manufacturers Light \& Heat Co. Altitude, 1,036 feet.]

\begin{tabular}{|c|c|c|c|}
\hline Stratum. & $\begin{array}{l}\text { Depth to } \\
\text { top. }\end{array}$ & Thickness. & $\begin{array}{l}\text { Depth to } \\
\text { bottom. }\end{array}$ \\
\hline 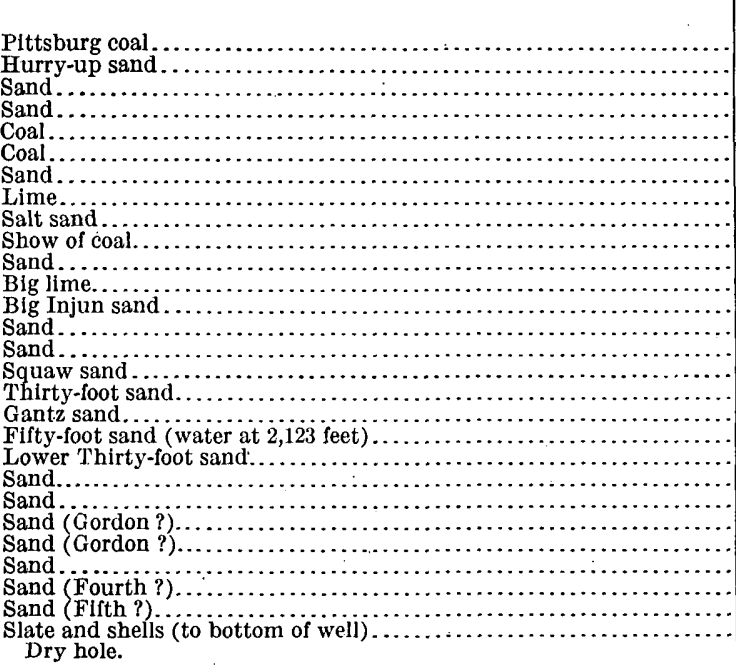 & \begin{tabular}{r|} 
Feet. \\
185 \\
525 \\
735 \\
760 \\
875 \\
930 \\
980 \\
1,090 \\
$1,150$. \\
1,285 \\
1,295 \\
1,327 \\
1,350 \\
1,625 \\
1,655 \\
1,700 \\
1,876 \\
2,060 \\
2,089 \\
2,190 \\
2,229 \\
2,262 \\
2,300 \\
2,326 \\
2,353 \\
2,394 \\
2,435 \\
2,485
\end{tabular} & $\begin{array}{r}\text { Feet. } \\
7 \\
20 \\
10 \\
30 \\
9 \\
10 \\
25 \\
40 \\
30 \\
\ldots . . \\
20 \\
23 \\
255 \\
18 \\
10 \\
40 \\
57 \\
22 \\
77 \\
10 \\
28 \\
9 \\
20 \\
24 \\
37 \\
21 \\
50 \\
265\end{array}$ & $\begin{array}{r}\text { Feet. } \\
192 \\
575 \\
745 \\
790 \\
884 \\
940 \\
1,005 \\
1,130 \\
1,180 \\
\ldots, 315 \\
1,315 \\
1,350 \\
1,605 \\
1,643 \\
1,665 \\
1,740 \\
1,933 \\
2,082 \\
2,166 \\
2,200 \\
2,257 \\
2,271 \\
2,320 \\
2,350 \\
2,390 \\
2,415 \\
2,485 \\
2,750\end{array}$ \\
\hline
\end{tabular}

Record of Parks well No. 1 (No. 234), Peters Township, Washington County, Pa.

[Altitude, 1,050 feet (?).]

\begin{tabular}{|c|c|c|c|}
\hline Stratum. & $\begin{array}{l}\text { Depth to } \\
\text { top. }\end{array}$ & Thickness. & $\begin{array}{l}\text { Depth to } \\
\text { bottom. }\end{array}$ \\
\hline 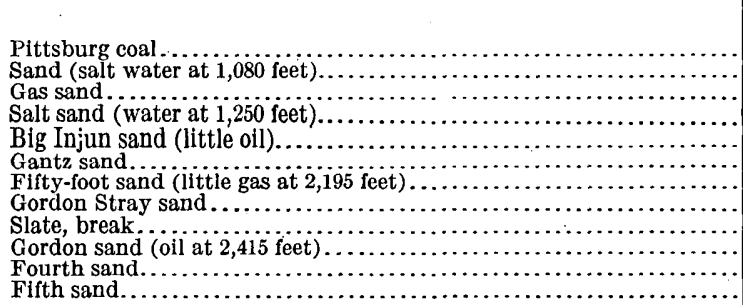 & $\begin{array}{r}\text { Feet: } \\
265 \\
900 \\
1,100 \\
1,220 \\
1,410 \\
2,137 \\
2,170 \\
2,365 \\
2,385 \\
2,395 \\
2,450 \\
2,510\end{array}$ & \begin{tabular}{r|} 
Feet. \\
$\cdots$ \\
$\cdots$ \\
60 \\
75 \\
250 \\
21 \\
60 \\
20 \\
10 \\
30 \\
25 \\
25
\end{tabular} & $\begin{array}{r}\text { Feet. } \\
\cdots \\
1,160 \\
1,295 \\
1,660 \\
2,158 \\
2,230 \\
2,385 \\
2,395 \\
2,425 \\
2,475 \\
2,535\end{array}$ \\
\hline Total depth. & & & 2,550 \\
\hline
\end{tabular}


Record of David Resse well No. 1 (No. 221), Peters Township, Washington County, Pa.

[Owned by Cambria Oil Co. Altitude, 1,027 feet.]

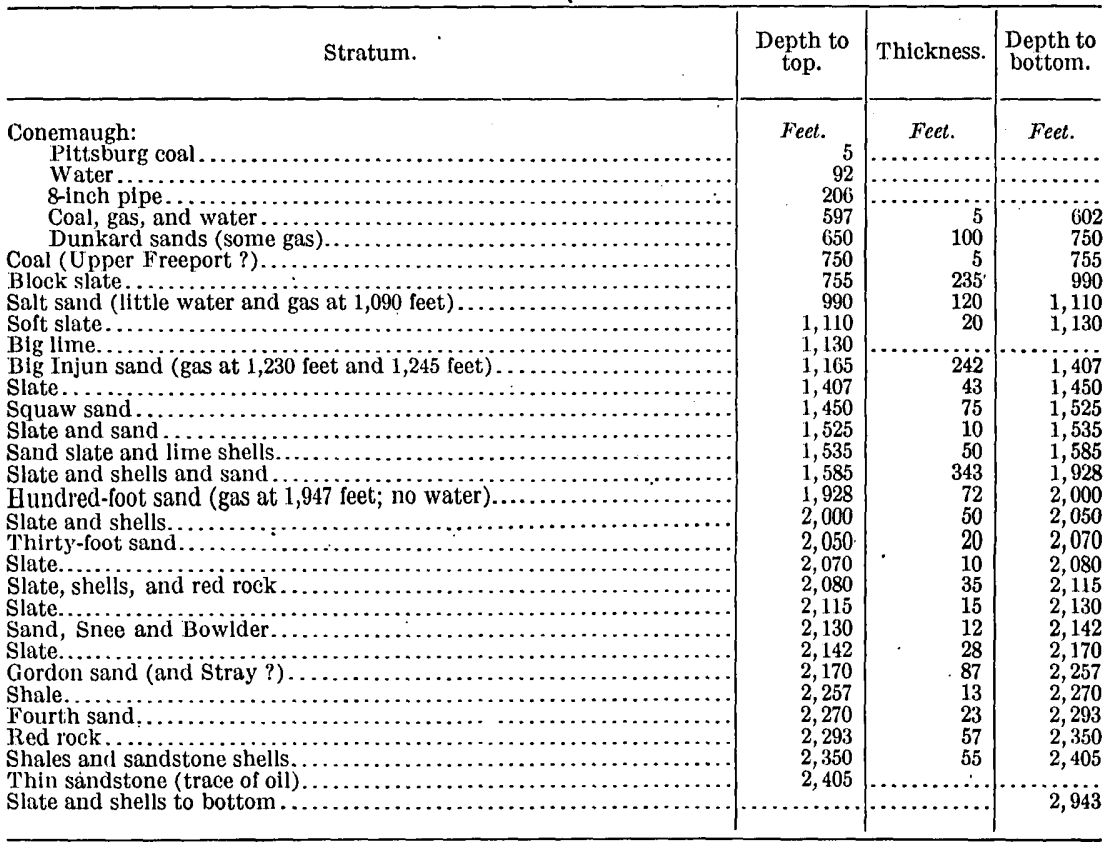

Record of J. L. McNairy well No. 2 (No. 244), Peters Township, Washington County, Pa. [Owned by Manufacturers Light \& Heat Co. Altitude, 1,050 feet.]

\begin{tabular}{|c|c|c|c|}
\hline Stratum. & $\begin{array}{l}\text { Depth to } \\
\text { top. }\end{array}$ & Thickness. & $\begin{array}{l}\text { Depth to } \\
\text { bottom. }\end{array}$ \\
\hline 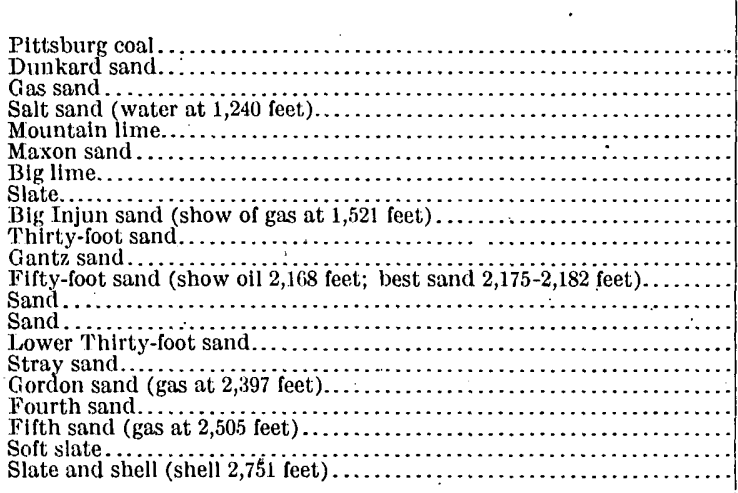 & $\begin{array}{r}\text { Feet. } \\
245 \\
780 \\
1,140 \\
1,220 \\
1,355 \\
1,367 \\
1,372 \\
1,410 \\
1,417 \\
1,990 \\
2,123 \\
2,153 \\
2,235 \\
2,280 \\
2,340 \\
2,375 \\
2,395 \\
2,450 \\
2,492 \\
2,527 \\
2,700\end{array}$ & $\begin{array}{r}\text { Feel. } \\
6 \\
55 \\
45 \\
30 \\
12 \\
5 \\
38 \\
7 \\
233 \\
60 \\
30 \\
29 \\
20 \\
20 \\
20 \\
16 \\
25 \\
13 \\
35 \\
173 \\
125\end{array}$ & $\begin{array}{r}\text { Feet. } \\
251 \\
835 \\
1,185 \\
1,250 \\
1,367 \\
1,372 \\
1,410 \\
1,417 \\
1,650 \\
2,050 \\
2,153 \\
2,182 \\
2,255 \\
2,300 \\
2,360 \\
2,391 \\
2,420 \\
2,463 \\
2,527 \\
2,700 \\
2,825\end{array}$ \\
\hline Total depth... & & & 2,860 \\
\hline
\end{tabular}


Record of Mary Johnston well No.13 (No.102), Finley Township, Allegheny County, Pa. [Owned by Manufacturers Light \& Heat Co. Altitude, 1,078 feet.]

\begin{tabular}{|c|c|c|c|}
\hline Stratum. & $\begin{array}{l}\text { Depth to } \\
\text { top. }\end{array}$ & Thickness. & $\begin{array}{l}\text { Depth to } \\
\text { botton. }\end{array}$ \\
\hline 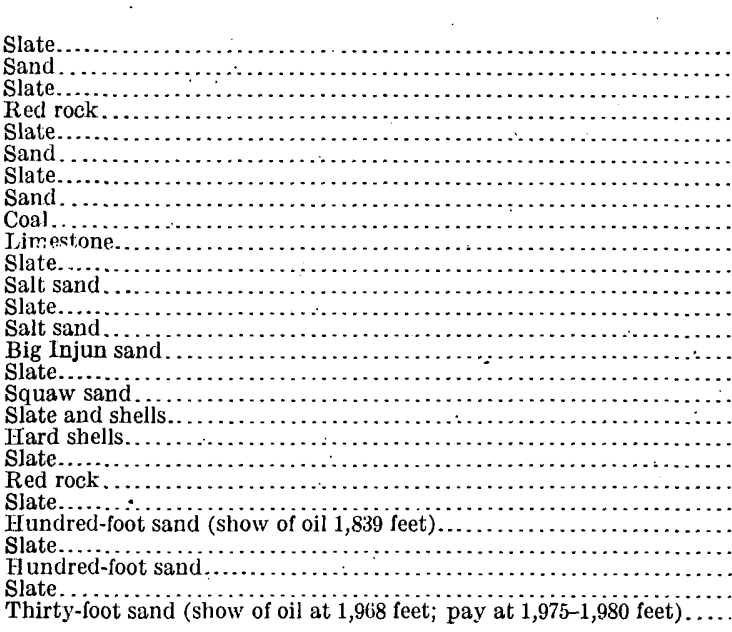 & $\begin{array}{r}\text { Feet. } \\
8 \\
58 \\
108 \\
158 \\
208 \\
308 \\
358 \\
508 \\
558 \\
563 \\
570 \\
820 \\
860 \\
870 \\
1,050 \\
1,300 \\
1,350 \\
1,390 \\
1,520 \\
1,720 \\
1,760 \\
1,770 \\
1,828 \\
1,847 \\
1,852 \\
1,872 \\
1,960\end{array}$ & $\begin{array}{r}\text { Feet. } \\
50 \\
50 \\
50 \\
50 \\
100 \\
50 \\
150 \\
50 \\
5 \\
7 \\
250 \\
40 \\
10 \\
105 \\
250 \\
50 \\
40 \\
130 \\
200 \\
40 \\
10 \\
58 \\
19 \\
5 \\
20 \\
88 \\
21\end{array}$ & $\begin{array}{r}\text { Feet. } \\
58 \\
108 \\
158 \\
208 \\
308 \\
358 \\
508 \\
558 \\
563 \\
570 \\
820 \\
860 \\
870 \\
975 \\
1,300 \\
1,350 \\
1,390 \\
1,520 \\
1,720 \\
1,760 \\
1,770 \\
1,828 \\
1,847 \\
1,852 \\
1,872 \\
1,960 \\
1,981\end{array}$ \\
\hline Total & & & 1,983 \\
\hline
\end{tabular}

Record of Pressed Steel Car Co. well No. 1 (No. 12S), McKees Rocks Township, Allegheny County, Pa.

[Owned by Pressed Steel Car Co. Altitude, 731 feet.]

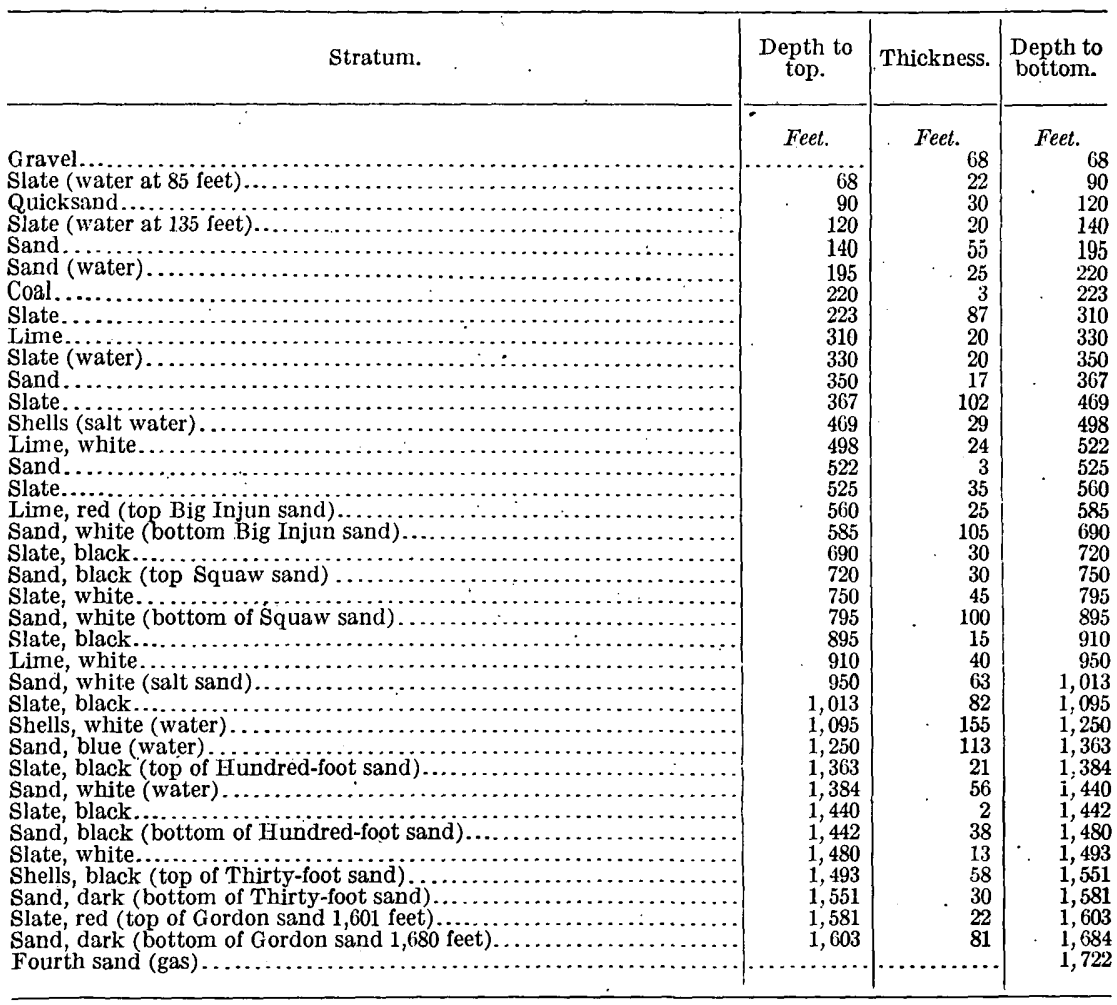


Record of S. B. Phillips well No. 1, McDonald field, North Fayette Township, Allegheny County, Pa.

[Owned by Woodland Oil Co.]

\begin{tabular}{|c|c|c|c|}
\hline Stratum. & $\begin{array}{l}\text { Depth to } \\
\text { top. }\end{array}$ & Thickness. & $\begin{array}{l}\text { Depth to } \\
\text { bottom. }\end{array}$ \\
\hline Unrecorded.. & Fect. & Feet. 86 . & Feet. \\
\hline Pittsbur & 86 & $\begin{array}{r}80 \\
4\end{array}$ & $\begin{array}{l}80 \\
90\end{array}$ \\
\hline Fire clay & 90 & 5 & 95 \\
\hline 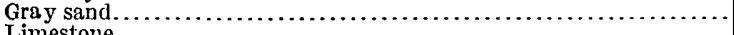 & 95 & 5 & 100 \\
\hline 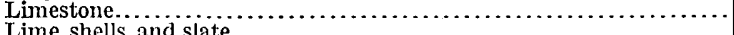 & 100 & 19 & 119 \\
\hline 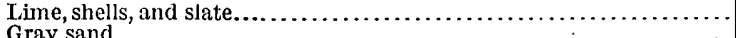 & 119 & 11 & 130 \\
\hline 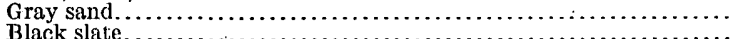 & 130 & 24 & 154 \\
\hline 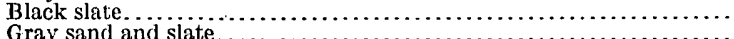 & 154 & 5 & 159 \\
\hline $\begin{array}{l}\text { Gray sand and slate............. } \\
\text { White slate. }\end{array}$ & 159 & 41 & 200 \\
\hline $\begin{array}{l}\text { White slate } \\
\text { Red rock }\end{array}$ & . 200 & 19 & 219 \\
\hline $\begin{array}{l}\text { Red rock } \ldots \ldots \ldots \ldots \ldots \ldots \ldots \ldots \ldots \ldots \ldots \ldots \ldots \ldots \ldots \\
\text { White slate. }\end{array}$ & 219 & 39 & 258 \\
\hline 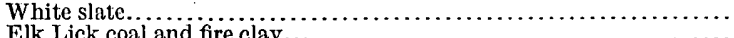 & 258 & 7 & 265 \\
\hline 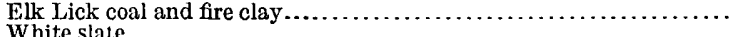 & 265 & 5 & 270 \\
\hline White slate..................... & 270 & 35 & 305 \\
\hline Black slate..................... & 305 & 72 & 377 \\
\hline White slate..................... & 377 & 10 & 387 \\
\hline Gray sand, soft...................... & 387 & 72 & 459 \\
\hline Black, red, and white slate........... & 459 & 16 & 475 \\
\hline 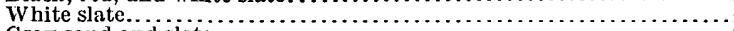 & 475 & 38 & 513 \\
\hline 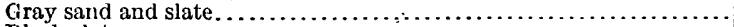 & 513 & 16 & 529 \\
\hline 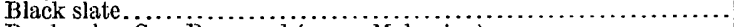 & 529 & 12 & 541 \\
\hline Dunkard or Cow Run sand (upper Mahoning) $\ldots \ldots \ldots \ldots \ldots \ldots \ldots \ldots$ & 541 & 50 & 591 \\
\hline 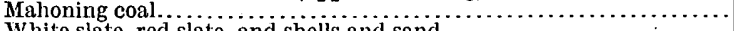 & 591 & 7 & 598 \\
\hline White slate, red slate, and shells & 598 & 105 & 703 \\
\hline 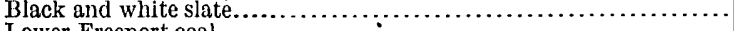 & 703 & 61 & 764 \\
\hline $\begin{array}{l}\text { Iower Freeport coal. } \\
\text { White slate lime, and shells }\end{array}$ & 764 & & $\begin{array}{l}771 \\
786\end{array}$ \\
\hline 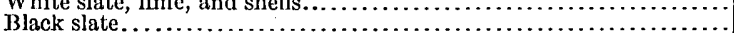 & 786 & $\begin{array}{l}15 \\
53\end{array}$ & 836 \\
\hline 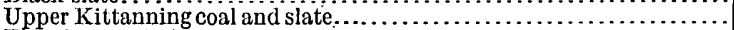 & 839 & 7 & 846 \\
\hline lay (water) & 846 & 6 & 852 \\
\hline Black slate and fire $\mathrm{cl}$ & 852 & 17 & 869 \\
\hline 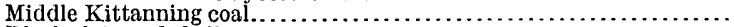 & 869 & 3 & 872 \\
\hline 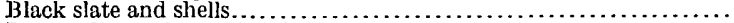 & 872 & & 884 \\
\hline . & 884 & 5 & 889 \\
\hline Black slate and shells and sand... & 889 & 34 & 923 \\
\hline ad, hard............. & 923 & 14 & 937 \\
\hline 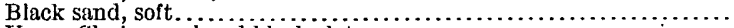 & 937 & 15 & 952 \\
\hline Upper $\mathrm{Cl}$ & 952 & & 957 \\
\hline lls. & 957 & 10 & 967 \\
\hline and black slat & 967 & 3 & 970 \\
\hline e and shells............ & 970 & 6 & 976 \\
\hline (2) & 976 & 217 & 1,193 \\
\hline - & 1,193 & 39 & 1,232 \\
\hline 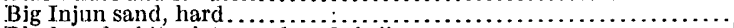 & 1,232 & 237 & 1,469 \\
\hline Black ai & 1,469 & 88 & 1,557 \\
\hline$y$ sand witl & 1,557 & 42 & 1,599 \\
\hline gray shales with some & 1,599 & 201 & 1,800 \\
\hline 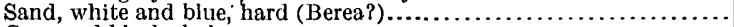 & 1,800 & 29 & 1,829 \\
\hline 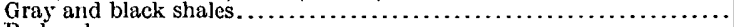 & 1,829 & 77 & 1,906 \\
\hline$\ldots \ldots \ldots \ldots \ldots \ldots \ldots \ldots \ldots \ldots$ & 1,906 & 14 & 1,920 \\
\hline te and shells............. & 1,920 & 12 & 1,932 \\
\hline Gantz sand, top of Hundred-foot; & 1,932 & & 1,959 \\
\hline $\begin{array}{l}\text { Slate break........ } \\
\text { Fifty-foot sand; hard, white, gra }\end{array}$ & & 11 & 1,97 \\
\hline and water is leet delow cop; & 1,970 & 46 & 2,016 \\
\hline 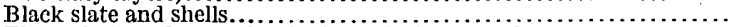 & 2,016 & 79 & 2,095 \\
\hline Thirty-foot sand, gray, hard (show of oil at 2,111 feet) . . . . . . . . & 2,095 & 25 & 2,120 \\
\hline 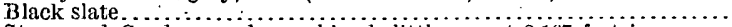 & 2,120 & 27 & 2,147 \\
\hline Stray and Gordon sands combined; little gas at 2,167 feet in upper & & & \\
\hline e portion (Gordon)... & 2,147 & 63 & 2,210 \\
\hline 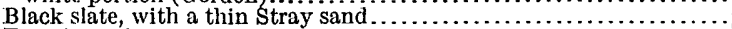 & 2,210 & & 2,253 \\
\hline h sand, gray and white, hard... & 2,253 & 20 & 2,273 \\
\hline Black slate and sand, hard............ & 2,273 & 38 & 2,311 \\
\hline Fifth or McDonald sand; pay streak, oil, 19 feet below top, a gray sand. & 2,311 & 24 & 2,335 \\
\hline Black slate to bottom of well.... & 2,335 & 7 & 2,342 \\
\hline
\end{tabular}

\section{ROCKS EXPOSED AT THE SURFACE.}

The rocks which outcrop in the Carnegie quadrangle are of no economic importance to oil producers, since none of them contain pools of oil or gas in paying quantities. These rocks are, however; of considerable geologic importance, since they furnish more or less accurate guides to the structure of the deeply buried oil and gas sands. 
For this reason a brief discussion of the outcropping beds will be undertaken in this paper, the detailed consideration of them being more appropriately reserved for publication in the geologic folio.

\section{CARBONIFEROUS SYSTEM.}

\section{PENNSYLVANIAN SERIES.}

CONEMAUGH FORMATION.

The lower portion of the Conemaugh formation, including the Mahoning sandstone member (Little and Big Dunkard sands), does not come to the surface in the quadrangle and has already been mentioned in the preceding section.

Saltsburg sandstone member.-The Saltsburg sandstone member is a fairly persistent sandstone from 50 to 120 feet thick, the top of which is about 275 feet above the base of the Conemaugh formation. It is barely above drainage in the northern portion of the quadrangle, but is noted in many detailed records in the quadrangle farther south. This sandstone has been correlated ${ }^{a}$ with the first Cow Run sand of West Virginia and Ohio, but it may be more nearly equivalent to the Hurry-up sand of that region. In the Carnegie quadrangle it is usually filled with fresh water, but farther south it contains important pools of oil and gas.

Morgantown sandstone member (Murphy sand).-The Morgantown sandstone member or Murphy sand is a fine-grained gray sandstone, ranging from 20 to 75 feet thick, with its top about 200 feet below the Pittsburg coal bed. Its outcrop encircles the hillsides in the northern part of the quadrangle, but it is below drainage in the southern part. In Greene County and farther southward this bed is an important source of gas and some oil; in that region it is said also to carry considerable quantities of salt water.

Overlying the Mahoning sandstone member and extending to the base of the Pittsburg coal are 200 feet of sandy yellowish and reddish shales, in which are embedded one or two thin beds of coal and limestone.

MONONGAHELA FORMATION.

The Monongahela formation, which is composed of beds of coal, shale, limestone, and sandstone, occupies the interval of 355 to 380 feet between the base of the Pittsburg coal and the top of the Waynesburg coal. The Redstone coal is 30 to 60 feet above the bottom, the Sewickley coal near the middle, and the Uniontown coal about 100 feet from the top of the formation. Of these, the Pittsburg and the Waynesburg are by far the most important. The others, being of little or no economic or stratigraphic value, will not be discussed in this paper. The more important members of the formation will be briefly described. 
Pittsburg coal.-The Pittsburg coal is the thickest and by far the most important coal bed of southwestern Pennsylvania. It is found in the Carnegie quadrangle, wherever its horizon is exposed or touched by the drill, with a thickness of from 7 to 14 feet, and with 5 to 6 feet of workable coal of good quality. Aside from its great economic value, which will not be touched upon here, this bed is of great stratigraphic importance to oil operators as well as to geologists. Covering as it does a very large area in Pennsylvania, Ohio, and West Virginia, it affords an ideal geologic marker by which other beds above and below it may be recognized. It is also used as a datum plane from which the structure both of rocks at the surface and of those underground may be calculated.

Pittsburg sandstone member.-The Pittsburg sandstone member is a persistent bed, from 20 to 50 feet thick, with its base a few feet above the Pittsburg coal. In this bed, in the southern part of Washington and in Greene counties, Pa., drillers sometimes find small pools of gas with indications of oil in a few locations.

Benwood limestone member.-Near the middle of the Monongahela - formation occurs the most prominent limestone bed of the Pennsylvanian series, the Benwood. By drillers this is usually designated the Big lime. It is from 75 to 100 feet thick and is composed of a number of thin white, gray, and blue limestones separated by thin beds of calcareous shale. Except as a geologic marker this bed is of no economic value to producers.

Uniontown sandstone member.-The Uniontown sandstone member is a thin gray or reddish sandstone overlying the Uniontown coal at about 275 to 290 feet above the Fittsburg coal. It is of no importance in the Carnegie quadrangle, but at Cairo, Ritchie County, W. Va., it is considered by I. C. White $e^{a}$ to be equivalent to the "shallow oil sand" and to be the highest known oil sand in that State. Small quantities of gas have been reported from a sand at about this horizon in Greene and Washington counties, Pa., where it is from 500 to 1,100 feet below drainage, but no definite relative data are available.

Waynesburg coal.-Over most of the Carnegie quadrangle the Waynesburg coal outcrops well up toward the tops of the hills. It is thin and inconspicuous, seldom showing more than 3 or 4 feet of soft dirty coal. It is of little economic or stratigraphic importance.

PERMIAN SERIES.

DUNKARD GROUP.

Washington formation.-In the southern part of Washington County this formation attains a thickness of about 400 feet, extending from the top of the Waynesburg coal to the top of the Upper Washington. limestone member. - It consists chiefly of sandstones and shales, with several thin limestones, and five or more unimportant coal beds. In 
the Carnegie quadrangle some of the highest hills and ridges carry as much as 200 feet of this formation, the upper portion having been removed by erosion. These rocks are of no value to oil and gas operators, and a detailed description of them will therefore be reserved for the folio of this quadrangle.

\section{STRUCTURE.}

\section{DEFINITIONS.}

By structure is meant the shape or "lay" of the strata. Since the great mass of sedimentary rocks described above were deposited they have been slowly raised and depressed many times by broad continental movements in the earth's crust. This process has been a more or less continuous one from the time the first beds were deposited. The producer of oil and gas is not interested in the deformation processes through which the strata have passed so much as he is in the results of that deformation. . The discussion of the structure of the Carnegie quadrangle will therefore be confined to the sum total of all the movements to which these beds have been subjected as represented by their present shape.

In describing structure an upward bending arch is called an anticline and a downward bending trough a syncline. The axis of a fold is a line, every point in which occupies the highest part of an anticline or the lowest part of a syncline.

METHOD OF REPRESENTING STRUCTURE.

The structure of a region may be represented on a map either by cross sections showing the dip of the beds along certain chosen lines or by the use of contour lines drawn through points of equal height at the top or bottom of some bed taken as a key rock. The first method is employed in areas where the beds are steeply folded and broken by faults; the latter is most successfully employed where the beds are but slightly disturbed from their originally horizontal position. The latter method is used to show the structure of the oil sands of the Carnegie quadrangle.

On the map (Pl. V) contour lines in green are drawn to show the shape of the upper surface of the Third or Gordon sand. These contours have a vertical interval of 10 feet, and each of them traces a level line along the slope of this sand at all points of which the top of the sand is a given height above a horizontal datum plane. For convenience, this datum is assumed to be 2,000 feet below sea level. Thus, the contour marked 800 on the map is a level line on the top of the sand, all points on which line are supposed to be 800 feet above the datum plane 2,000 feet below sea level. In like manner the 1,000-foot contour marks all points at the top of the sand which are 1,000 feet above the same datum plane, and along this line the sand is therefore 1,000 feet below sea level. 


\section{ACCURACY OF STRUCTURE CONTOURS.}

The accuracy with which the structure contours on a given bed represent the shape of that bed depends of course upon the number and position of the points on this key horizon at which the exact height of the bed has been secured, and also to a less extent upon the skill employed in interpreting the shape of the bed from these data.

The contours on the Third or Gordon sand shown in Plate V vary greatly in accuracy from point to point because of the difference in the amount and quality of the information upon which they were based.

Material employed.-The data used in the construction of the contour map of the Gordon sand, which lies from 2,000 to 3,000 feet below the surface, were spirit-level lines run to the mouths of most of the wells and measurements from the mouth of each well to the top of the Gordon sand. The levels were run by the writer and his assistants. The measurements were secured from records of the wells obtained from owners. In this way the altitudes of hundreds of points on the top of the Gordon sand were determined within a possible limit of error of 5 feet. In the well-developed fields this material was sufficiently plentiful to assure the fairly accurate location of the contours. In areas where few wells have been drilled, the positive elevations obtained on the Gordon sand were too widely scattered to admit of more than a very general delineation of the structure. To increase the accuracy of the contours between these isolated points, a contour map of the Pittsburg coal, which shows at the surface, was carefully prepared. ${ }^{a}$ By superimposing the map of the Gordon sand on this map and drawing the contours of the sand to correspond with those on the coal in places where the material is scanty for the oil sand, a fairly accurate structural map of the oil sand was secured.

A contour map of the oil sand thus prepared is not accurate in detail, since the two beds seldom if ever lie parallel to each other over even a single square mile. To eliminate this source of error, the writer has heretofore resorted to the use of what is known as a.convergence sheet by which the approximate distance between the two key horizons may be estimated at all points. By thus inserting the correction for convergence of the strata the contours on the surface bed may be so altered in places as to make them correspond more closely to the surface of the underground bed. Such corrections, however, are of greatest value in areas where the variation in distance between the key horizons is fairly uniform over considerable areas. If the variation is irregular, a convergence sheet is of little value unless a large number of measurements between the two key

a The structural map of the Pittsburg coal was made by G. C. Martin in connection with work for a folio of this quadrangle. 
horizons are available. In such cases, only the general structural features of the oil sand can be determined. Such a condition probably exists in the Carnegie quadrangle. Here the Pittsburg coal

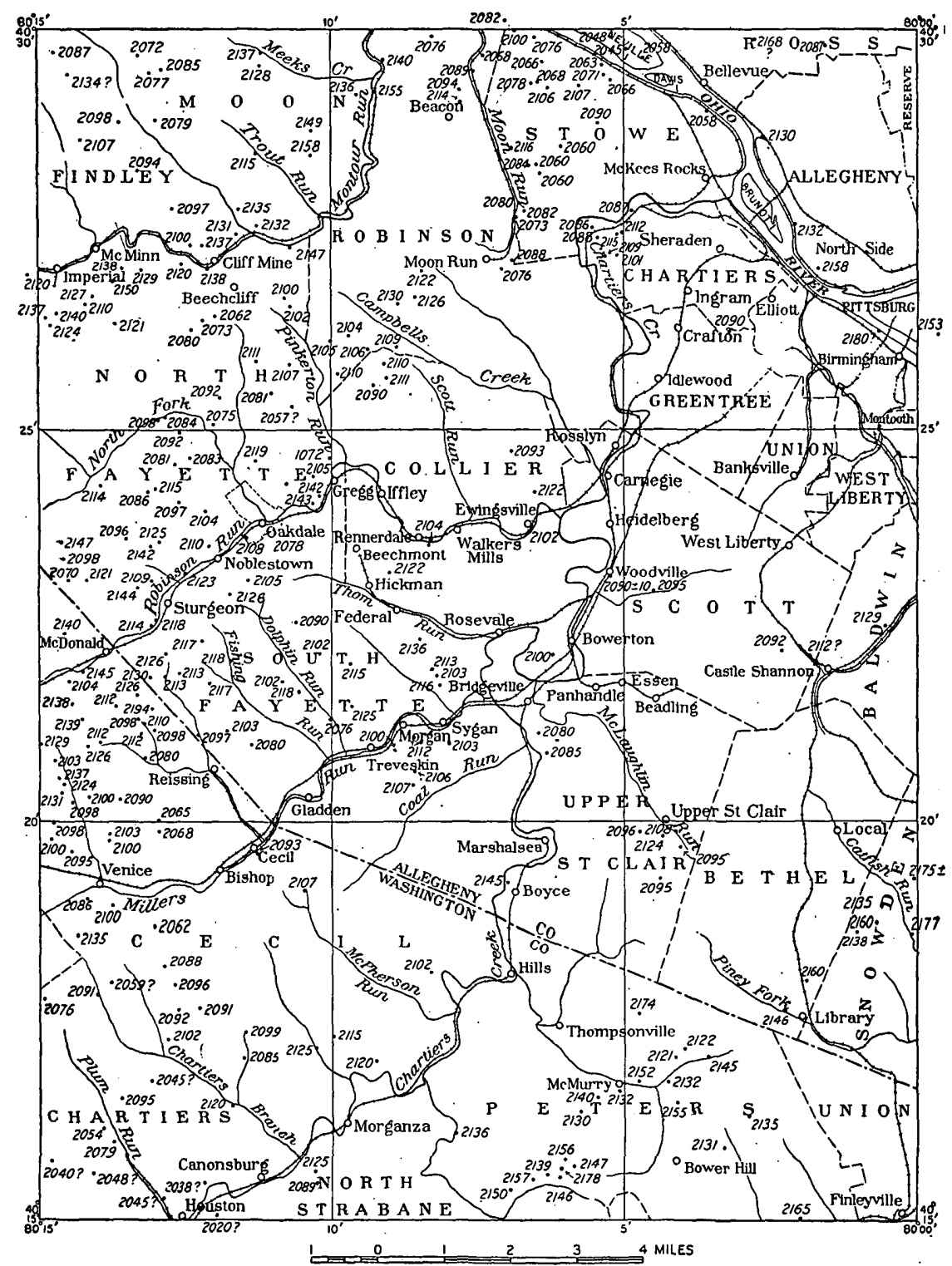

FigURE 1.- Sketch map of the Carnegie quadrangle showing the distance in feet between the top of the Pittsburg coal and the top of the Gordon sand. The variation in this interval is probably due, in large part, to the unconformity at the base of the Pottsville formation.

appears to have been deposited on an irregular surface, portions of which had been previously subjected to erosion, thus introducing sharp local changes in distance between it and the Gordon sand (see 
fig. 1), which materially decrease the possibility of securing from it aecurate contours on the oil sand. Because of this difficulty the convergence sheet of this quadrangle has been employed only in a very limited way, and in areas where no wells occur the contours on the Gordon sand are generalized to show only the principal structural features.

\section{STRUCTURAL FEATURES OF THE GORDON SAND.}

From the contours shown on Plate IV (in pocket) it will be seen that in the Carnegie quadrangle and in the region surrounding it the rocks which originally lay in practically horizontal beds have been slightly tilted as a whole southeast and south, and they have also been wrinkled into irregular folds having a general northeast-southwest to north-south trend.

Nineveh syncline.-The most prominent and well-defined fold in the Carnegie quadrangle (see Pl. V, in pocket) is a broad flat-bottomed syncline which extends from the southern border in the eastern part of North Strabane Township in a north-northeast direction to the vicinity of Pittsburg. This appears to be the northern extension of the Nineveh syncline of Washington and Greene counties. East and southeast of this trough the rocks rise irregularly to the axis of the Amity anticline; northwest from it the beds have been wrinkled into a large number of short crooked troughs and low arches having a general north-south trend. The tendency to develop a system of northeast-southwest folds is hardly perceptible in this part of the quadrangle, the folding apparently being secondary to the Nineveh syncline. The bottom of this trough is not horizontal, but rises rapidly, toward the north, the comparatively uniform pitch of the fold being interrupted in two places by small oval-shaped basins. The center of the deepest of these basins, and structurally the lowest point in the quadrangle, is near the junction of Chartiers and Little Chartiers Creeks, about $2 \frac{1}{2}$ miles northeast of Canonsburg. The top of the Gordon sand in the center of this basin is about 650 feet lower than it is near the northeast corner of the quadrangle, which is structurally the highest place in the area. The next basin to the north in this trough at Woodville near the center of the quadrangle is about 150 feet above the first. From this basin the axis of the syncline rises steadily northward to the junction of Allegheny and Monongahela Rivers in Pittsburg, where it is about 190 feet higher. Northeast of this point no data relative to the structure of the Gordon sand were obtained. The strongest dips in the Gordon sand appear to occur in that vicinity and along the western limb of this syncline from Pittsburg to Canonsburg. At the latter point the beds rise toward the west at the rate of about 225 feet to the mile, an unusually steep dip for this region. 
Amity anticline.-The Amity anticline is a well-defined arch which extends across the Amity quadrangle, with a general northeastsouthwest trend, and crosses the southeast corner of the Carnegie quadrangle. In the Carnegie quadrangle the highest point of the Gordon sand on this anticline is about 340 feet above the lowest point in the Nineveh syncline and about 150 feet above the adjacent trough of the McMurry syncline.

McMurry syncline.-The name McMurry syncline is locally applied to a secondary trough which branches off from the Nineveh syncline northwest of McMurry. For the first 3 miles from the Nineveh syncline this trough has a general trend east, then it gradually swings northeastward, leaving the eastern border of the quadrangle about $4 \frac{1}{2}$ miles from the southeast corner. Owing to the scarcity of positive elevations on the Gordon sand along the probable course of this trough and farther north, its exact position could not be determined, nor is the writer at all certain that the structural features shown by the contours between this trough and Castle Shannon are as represented. This is also true of the area lying north of Upper St. Clair and east of Brïgeville and Woodville.

Cross Creek syncline.-The Cross Creek syncline was first named by Griswold. ${ }^{a}$ It is a canoe-shaped basin in the central part of the Burgettstown quadrangle, which adjoins the Carnegie quadrangle on the west. This trough has an east-west trend, and toward the east it rises to a low divide near the boundary between the two quadrangles, from which it deepens and widens to the basin in the Nineveh syncline, 2 miles northeast of Canonsburg.

Washington anticline.-The fold that has been called the Washington anticline is one of the most important structural features of the Claysville quadrangle, which joins the Carnegie quadrangle on the sou thwest. It crosses the northwest corner of the Amity quadrangle, entering the Carnegie quadrangle from the south about 1 mile from the southwest corner. From this point the fold appears to die out very abruptly against the Cross Creek syncline. It seems possible, however, that this arch may swing sharply northwest across the southwest corner of the quadrangle and unite with the Claysville anticline off the western border of the quadrangle in the vicinity of the Westland Dome, south of Hickory.

Wildwood anticline.-North of the Cross Creek syncline and west of the Nineveh syncline the rocks are wrinkled into a large number of small shallow troughs which die out north and northwest. The most prominent fold that can be detected in the rocks of this portion of the quadrangle appears to be the southern extension of the Wildwood anticline, a clearly defined fold which crosses the Sewickley quad- 
rangle on the north with a northeast-southwest trend, and enters the northern border of the Carnegie quadrangle a little west of its middle point. From this point the fold dies out rapidly toward the south and is barely traceable as a low sinuous arch to the vicinity of Oakdale, where it disappears in the irregular wrinkling referrod to above.

Mount Nebo syncline.-On the Sewickley quadrangle the Mount Nebo syncline is the first trough west of the Wildwood anticline. Near the southern border of that quadrangle this trough unites with the Sewickley syncline on the west. Southward this trough enters the Carnegie about 1 mile northwest of Ewing's Mill and roughly parallels the Wildwood anticline to the vicinity of McDonald, where it appears to bend abruptly west for about a mile, thence southward in a narrow shallow trough, uniting with the Cross Creek syncline about 1 mile east of Venice. Northwest of this fold the rocks rise slowly and irregularly to the corner of the quadrangle.

\section{OII AND GAS POOLS OF CARNEGIE QUADRANGLE.}

\section{CHARTIERS TOWNSHIP, WASHINGTON COUNTY.}

A portion of Chartiers Township is included in the southwestern corner of the Carnegie quadrangle. With the exception of a narrow belt along Chartiers Creek at Canonsburg, no oil has yet been found in paying quantity in this portion of the township, though almost the entire area is gas producing. The gas comes from the Fifth, the Fourth, the Third or Gordon, the Third Stray or Gordon Stray, the Fifty-foot, the Gantz, and the Murrysville sands, the largest pools probably being found in the Fifty-foot and the Fourth sands. This gas area is the eastern part of the great gas field lying in Chartiers, Mount Pleasant, Hopewell, Canton, and Buffalo townships, Washington County, which has been furnishing Pittsburg with a large volume of gas for more than 20 years. This portion of the township, however, is situated, structurally, on the eastern slope of a large dome on the Claysville and Washington anticline, the crest of which lies south of Hickory in Mount Pleasant Township. The eastern dip of the rocks across this township is above the average for this region, the maximum in a few places being probably as much as 225 feet to the mile. The closed pressure and capacity of the gas wells appear to bear no direct relation to the geologic structure, though reliable information regarding these phenomena is too meager to justify a definite statement. Most of these wells have been drilled for a number of years and the gas is now greatly depleted.

$83448^{\circ}-$ Bull. $456-11-3$ 
The following well records are typical of the better ones obtained in the township. The locations of these wells are indicated by the corresponding map numbers on Plate IV.

Partial records of deep wells in Chartiers Township, Washington County, Pa.

\begin{tabular}{|c|c|c|c|c|c|c|c|c|}
\hline $\begin{array}{l}\text { Map } \\
\text { No. }\end{array}$ & Name. & Owner. & $\begin{array}{l}\text { Alti- } \\
\text { tude. }\end{array}$ & Name of stratum. & $\begin{array}{l}\text { Depth } \\
\text { to top. }\end{array}$ & $\begin{array}{l}\text { Thick- } \\
\text { ness. }\end{array}$ & $\begin{array}{l}\text { Total } \\
\text { depth } \\
\text { of } \\
\text { well. }\end{array}$ & Remarks. \\
\hline 1 & J. C. McNary.... & $\begin{array}{l}\text { Manufacturers } \\
\text { Light \& Heat } \\
\text { Co. } \\
\text { ? }\end{array}$ & $\begin{array}{l}\text { Feet. } \\
1,175 \\
.\end{array}$ & $\begin{array}{l}\text { Pittsburg coal... } \\
\text { Gantz sand...... } \\
\text { Fifty-foot sand.. } \\
\text { Gordon Stray... } \\
\text { Gordon sand.... } \\
\text { Fourth sand.... } \\
\text { Fifth sand..... }\end{array}$ & $\begin{array}{r}\text { Feet. } \\
60 \\
1,885 \\
1,910 \\
2,074 \\
2,125 \\
2,174 \\
2,230\end{array}$ & $\begin{array}{c}\text { Feet. } \\
\cdots \cdots \\
\cdots \cdots \\
\cdots \cdots \\
\cdots \cdots \\
\cdots \cdots \\
\cdots \cdots \\
\cdots \cdots \\
\cdots \cdots \\
\end{array}$ & \begin{tabular}{c} 
Fect. \\
2,410 \\
\hdashline$\ldots \cdots$ \\
$\cdots \cdots$ \\
$\cdots \cdots$ \\
$\cdots \cdots$ \\
$\cdots \cdots$ \\
$\cdots \cdots$ \\
$\cdots$
\end{tabular} & . \\
\hline 2 & T. Thompson... & . & 1,212 & $\begin{array}{l}\text { Pittsburg coal:.. } \\
\text { Salt sand........ } \\
\text { Big Injun sand.. } \\
\text { Thirty-foot sand } \\
\text { Gantz sand...... } \\
\text { Fifty-foot sand.. } \\
\text { Gordon sand.... } \\
\text { Hund re d-foot } \\
\text { sand. }\end{array}$ & $\begin{array}{r}205 \\
1,070 \\
1,317 \\
1,870 \\
2,000 \\
2,030 \\
2,300 \\
2,380\end{array}$ & $\begin{array}{r}80 \\
230 \\
50 \\
15 \\
56 \\
40 \\
20\end{array}$ & 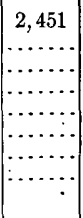 & - \\
\hline 3 & $\begin{array}{l}\text { J. R. Campbell. . } \\
\text {. }\end{array}$ & $\begin{array}{c}\ldots . . \text { do......... } \\
.\end{array}$ & 1,149 & $\begin{array}{l}\text { Gordon Stray... } \\
\text { Gordon sand.... } \\
\text { Hickory sand... } \\
\text { Hund re d-foot } \\
\text { sand. }\end{array}$ & $\begin{array}{l}2, \dot{200} \\
2,235 \\
2,300 \\
2,340\end{array}$ & $\begin{array}{l}30 \\
25 \\
15 \\
20\end{array}$ & $\begin{array}{c}2,359 \\
\ldots \ldots \ldots \\
\ldots \ldots \ldots\end{array}$ & \\
\hline 4 & J. B. Little..... & $\ldots$ do ............ & 997 & $\begin{array}{l}\text { Gantz sand...... } \\
\text { Fifty-foot sand.. } \\
\text { Stray sand...... } \\
\text { Gordon sand.... } \\
\text { "Hickory" sand }\end{array}$ & $\begin{array}{l}1,746 \\
1,780 \\
1,965 \\
2,020 \\
2,070\end{array}$ & $\begin{array}{l}16 \\
77 \\
55 \\
30 \\
22\end{array}$ & $\begin{array}{l}2,090 \\
\ldots \ldots \ldots \\
\ldots \ldots \\
\cdots \ldots \\
\cdots\end{array}$ & $\begin{array}{l}\text { Gas at } 1,752 \\
\text { and } 1,763 \\
\text { feet. } \\
\text { Good gas at } \\
2,083 \text { feet. }\end{array}$ \\
\hline 5 & .... do......... & ....do.......... & $\begin{array}{l}1,023 \\
\cdot\end{array}$ & $\begin{array}{l}\text { Thirty-foot sand } \\
\text { Gantz sand..... } \\
\text { Fifty-foot sand.. } \\
\text { Stray sand..... } \\
\text { Gordon sand... }\end{array}$ & $\begin{array}{l}1,648 \\
1,786 \\
1,816 \\
1,992 \\
2,040\end{array}$ & $\begin{array}{l}25 \\
24 \\
32 \\
48 \\
20\end{array}$ & $\begin{array}{l}\ldots \ldots \\
\cdots \ldots \\
\cdots \ldots \\
\cdots \ldots \\
\cdots \cdots \\
\cdots\end{array}$ & $\begin{array}{l}\text { Gas in Stray } \\
\text { and Gor- } \\
\text { don sands. }\end{array}$ \\
\hline 6 & R. D. Scott... & .... do......... & 1,114 & $\begin{array}{l}\text { Big Injun sand.. } \\
\text { Gantz sand..... } \\
\text { Fifty-foot sand.. } \\
\text { Gordon sand.... } \\
\text { Fourth sand... }\end{array}$ & $\begin{array}{l}1,335 \\
2,057 \\
2,080 \\
2,290 \\
2,419\end{array}$ & $\begin{array}{r}40 \\
5 \\
25 \\
30 \\
-\quad 10\end{array}$ & $\begin{array}{c}2,502 \\
\ldots \ldots \\
\cdots \ldots \\
\cdots \ldots \\
\cdots \ldots\end{array}$ & $\begin{array}{l}\text { Little gas on } \\
\text { top Fifty- } \\
\text { foot sand. }\end{array}$ \\
\hline 30 & Alexander, No. 1 & $\begin{array}{l}\text { Canons burg } \\
\text { Steel \& Iron } \\
\text { Works. }\end{array}$ & 1,020 & 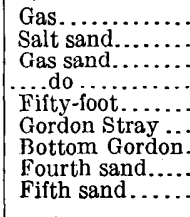 & $\begin{array}{r}754 \\
950 \\
1,211 \\
1,802 \\
1,850 \\
2,035 \\
2,095 \\
2,123 \\
2,131\end{array}$ & $\mid \begin{array}{r}\cdots \\
\cdots \cdots \\
\cdots \cdots \\
\cdots \cdots \\
56 \\
\therefore \cdots \\
\cdots \cdots \\
20 \\
59\end{array}$ & 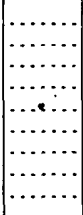 & 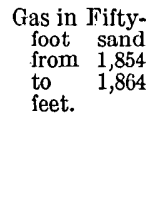 \\
\hline 31 & T. & $\ldots \ldots \ldots \ldots \ldots$ & 978 & $\begin{array}{l}\text { Pittsburg coal... } \\
\text { Gas sand....... } \\
\text { Salt sand....... } \\
\text { Big Injun sand. } \\
\text { T h i r t y - f o o t } \\
\text { (shells). } \\
\text { Gantz sand..... } \\
\text { Fifty-foot sand. } \\
\text { Gordon Stray... } \\
\text { Gordon sand ... } \\
\text { Fifth sand...... }\end{array}$ & $\begin{array}{r}135 \\
900 \\
1,085 \\
1,275 \\
1,800 \\
\\
1,960 \\
2,005 \\
2,190 \\
2,217 \\
2,355\end{array}$ & $\begin{array}{r}\cdots \\
20 \\
90 \\
215 \\
100 \\
\cdot \\
35 \\
40 \\
25 \\
23 \\
10\end{array}$ & $\begin{array}{l}\ldots \\
\ldots \\
\ldots \\
\cdots \\
\cdots \\
\cdots\end{array}$ & $\begin{array}{c}\text { Gas in Fifth } \\
\text { sand at } \\
2,360 \text { feet. }\end{array}$ \\
\hline
\end{tabular}


From these records it will be seen that the nomenclature of the drillers is by no means uniform. From such material alone it would be very difficult to trace with certainty a gas-bearing sand from one portion of the quadrangle to another, and in many places the stratigraphic facts when taken collectively are not sufficient to justify positive identifications. A close examination of the well sections of Plates II and III will show more clearly the uncertainty of close correlation in this township.

Comparatively few records were obtained of wells in this township, hence the structural contours of the Third or Gordon sand are based largely on those of the surface rocks, and are therefore doubtless more or less inaccurate in smaller details:

\section{CECIL TOWNSHIP, WASHINGTON COUNTY.}

Cecil Township lies northeast of Chartiers Township; and extends northwest from Chartiers Creek along the county line to McDonald and west beyond the border of the quadrangle. It is one of the great- est oil-producing townships of Washington County. The McDonald and Venice fields cover the northern portion of this area, and from the Cecil and Mawhinney pools and the Canonsburg field large quantities of oil have been obtained.

Canonsburg oil and gas field.--In the Canonsburg field the Fifth sand is found to be oil bearing in all of the productive area with the possible exception of a portion of the field immediately northeast of Canonsburg, where in places the sand is said to be absent. This sand is especially productive on the Patton, Reed, Moore, Weaver, and White farms, as well as on a number of other farms in the western portion of the field. At several places in this field the Gordon Stray or the Gordon sand is very productive.

Considerable trouble has been experienced by drillers in distinguishing in this locality between the Gordon and the Gordon Stray sands, since they often seem to unite into a single sandstone. At some places there is apparently no "break" between them, but at other places these sands. are separated by several feet of shale. From all available evidence on this point the writer is inclined to consider the entire sandstone where no "break" occurs as being more nearly equivalent to the true Gordon sand, and that the Gordon Stray is variable in thickness from place to place. In this field the average distance from the top of the Pittsburg coal to the top of the true Gordon sand is about 2,100 feet, with a maximum variation of about 20 feet from the average. 
The following typical logs of wells show clearly the difficulty of arriving at a satisfactory solution of this problem from imperfect well records:

Partial records of deep wells in Canonsburg field, Cecil Township, Washington County, Pa.

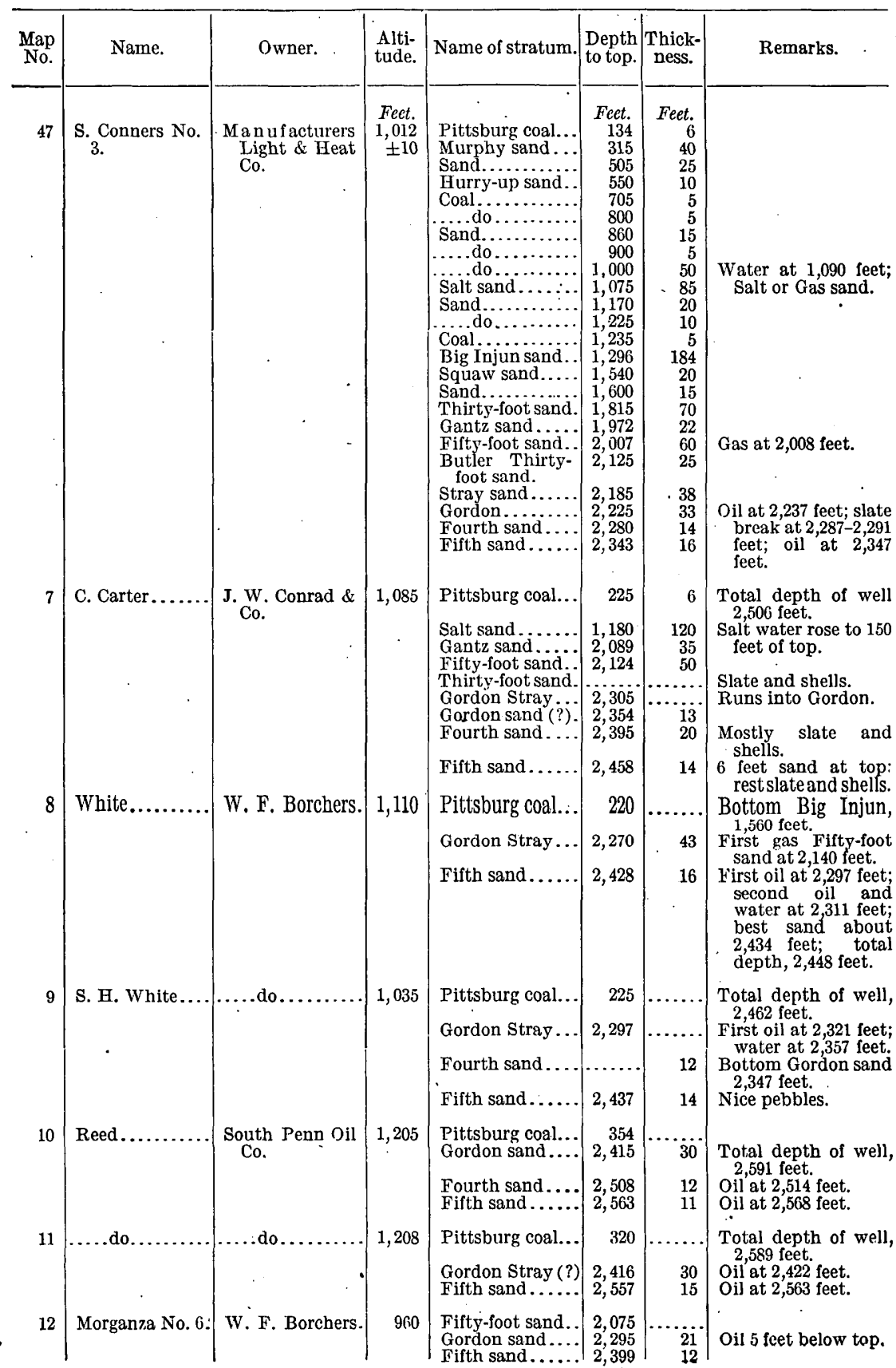


Partial rccord of deep wells in Canonsburg field, Cecil Township, Washington County, Pa.-Continued.

\begin{tabular}{|c|c|c|c|c|c|c|c|}
\hline $\begin{array}{l}\text { Map } \\
\text { No. }\end{array}$ & Name. & Owner. & $\begin{array}{l}\text { Alti- } \\
\text { tude. }\end{array}$ & Name of stratum & $\begin{array}{l}\text { Depth } \\
\text { to top. }\end{array}$ & $\begin{array}{l}\text { Thick- } \\
\text { ness. }\end{array}$ & Remarks. \\
\hline 13 & $\begin{array}{l}\text { W. T. Denny } \\
\text { No. } 1 .\end{array}$ & W. F. Botchers. & $\begin{array}{l}\text { Feet. } \\
1,077\end{array}$ & $\begin{array}{l}\text { Pittsburg coal... } \\
\text { Gordon Stray... } \\
\text { Gordon sand.... } \\
\text { Fifth sand..... }\end{array}$ & 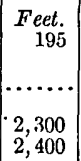 & $\begin{array}{l}\text { Feet. } \\
\ldots \\
\therefore \ldots .\end{array}$ & $\begin{array}{l}\text { Total depth of well, } \\
2,416 \text { feet. } \\
\text { Oil near top }(2,251 \\
\text { feet). } \\
\text { Little oil; hard sand } \\
\text { above. }\end{array}$ \\
\hline 14 & R. D. Scott.... & $\begin{array}{l}\text { South Penn Oil } \\
\text { Co. }\end{array}$ & 1,296 & $\begin{array}{l}\text { Pittsburg coal... } \\
\text { Fourth sand .... } \\
\text { Fifth sand...... }\end{array}$ & $\begin{array}{r}410 \\
2,528 \\
2,593\end{array}$ & $\begin{array}{l}15 \\
16\end{array}$ & $\begin{array}{l}\text { Total depth of well, } \\
2,624 \text { feet. }\end{array}$ \\
\hline 15 & $\begin{array}{l}\text { J. M. White No. } \\
\text { 1. }\end{array}$ & $\begin{array}{l}\text { Miller \& Abra- } \\
\text { ham, McDon- } \\
\text { ald, Pa. }\end{array}$ & 1,097 & $\begin{array}{l}\text { Gordon sand.... } \\
\text { Fourth sand .... } \\
\text { Fifth sand...... }\end{array}$ & $\begin{array}{l}2,210 \\
2,306 \\
2,403\end{array}$ & $\begin{array}{r}66 \\
34 \\
9\end{array}$ & $\begin{array}{l}\text { Gordon and Gordon } \\
\text { Stray sands, to- } \\
\text { gether without } \\
\text { break. }\end{array}$ \\
\hline 32 & $\begin{array}{l}\text { J. W. Howell } \\
\text { No. } 2 \text {. }\end{array}$ & $\begin{array}{l}\text { South Penn Oil } \\
\text { Co. }\end{array}$ & 1,197 & $\begin{array}{l}\text { Pittsburg coal... } \\
\text { Fifty.foot sand.. } \\
\text { Gordon sand.... } \\
\text { Fourth sand.... } \\
\text { Fifth sand..... }\end{array}$ & $\begin{array}{r}326 \\
2,203 \\
2,380 \\
2,475 \\
2,536\end{array}$ & ….... & $\begin{array}{l}\text { Total depth of well, } \\
2,573 \text { feet. } \\
\text { Oil at } 2,206 \text { feet. }\end{array}$ \\
\hline
\end{tabular}

The Hundred-foot sand, consisting of the Gantz and the Fifty-foot, also furnishes a considerable amount of both oil and gas. The production from these sands appears to come from several small pools which seem to be entirely cut off from one another. These have been most productive in the eastern part of the field, where some wells furnish oil from as many as three pay stréaks in the Hundred-foot sand.

In the Canonsburg field the Fourth sand, where productive, is oftener gas bearing, though it has furnished oil in several good wells. Going north from the center of this field the percentage of oil wells in this sand gradually increases until in the Venice field it is the principal oil producing sand. Gas is also reported in a few wells from the Salt or Gas sand, which is equivalent to one or more of the Pottsville sandstones. These sands, together with the Big Injun sand below them, are the principal source of salt water within the field. This water is found in varying quantities and head from well to well. One well may fill up a thousand feet with water when drilled into one of these sands, while the water in another well, only a few hundred yards away, may show only a few feet of head. Of the oil-bearing beds, the Fifty-foot sand probably contains the most water, though the Gordon Stray and the Gordon sands have furnished small quantities of water in a number of wells. The Fourth and the Fifth sands afford no water. From the incomplete information in hand it seems that the generally recognized water conditions in the Hundred-foot and the Gordon sands hold in this field. The remarkable difference between the behavior of the salt water in these sands.lies in the fact that salt water in the Hundred-foot sand tends to assist 
production and to extend the life of a well, whereas water in the Gordon sand retards production and materially shortens the time a well will continue to produce. In the first case the water is exhausted with the oil; in the second, the salt water usually increases with pumping, and generally results in a corresponding decrease in the oil until finally the well furnishes salt water exclusively. These characteristics are very pronounced in the fields farther north, in Beaver, Allegheny, and Butler counties. ${ }^{a}$

Although the maximum production from this field was great, few wells made phenomenal flows, and only a small percentage of them had an initial production of more than 200 barrels per day. Though the field long ago. reached "settled" production, the wells show good staying qualities, and many of them will doubtless be pumped many years before becoming exhausted.

Mawhinney oil pool.-The Mawhinney oil pool was opened in 1895 on the James Mawhinney and P. S. Walker farms; situated about 1 mile south of Cecil. The oil was found congested into a small pool of high pressure in the Fifty-foot sand. With a few exceptions the wells had a comparatively large initial production and decreased rapidly until exhausted. Only a small number of the wells that have produced oil in this pool are shown on the map (Pl. IV); the others have long since been abandoned and all indications of their locations obliterated. The largest well in the pool was the James Mawhinney No. 2, a record of which is given below. This well when drilled 5 feet into the Fifty-foot sand began flowing oil through a 6-inch hole over 2,250 feet deep at the rate of 160 barrels per hour. In May, 1908, several barrels per day were still being pumped from this well. At that date but two other wells in the pool were producing; these were the James Mawhinney No. 4 and the P. S. Walker No. 5, which together yielded only 2 or 3 barrels per day. In the following records of these three wells attention is called to the variation in depth below the top of the sand at which the oil was found from west to east across the pool.

Partial records of three wells in Mawhinney pool, Cecil Township, Washington.County, $P a$.

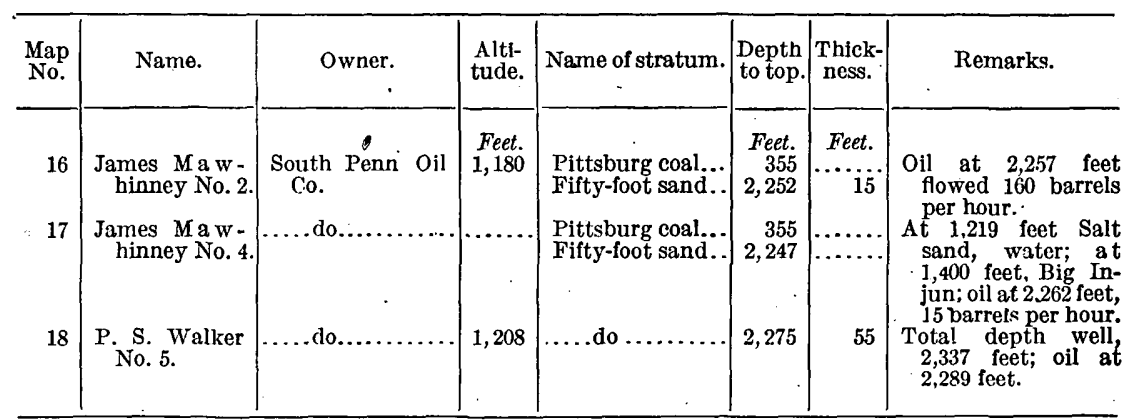

$a$ See oil and gas bulletin of Sewickley quadrangle, published by Top. and Geol. Survey Commission, Pennsylvania. 
From these records it will be seen that in well No. 16 the greatest volume of the oil was obtained when the well had penetrated the sand to a depth of only 5 feet, in well No. 17 the maximum flow occurred 15 feet below the top, and in well No. 18 the oil was found after drilling 14 feet in the sand. Little or no water was found in the Hundred-foot sand in this pool.

Cecil oil pool.-In its prime the Cecil oil pool contained more than 100 producing wells. All of these are now abandoned with the single exception of the August Behling No. 1 well (No. 19), from which a small quantity of oil is still pumped. Little information relative to this pool was secured in the field. It was opened during the excitement following the drilling of the Mawhinney gushers in 1895. Many wells with good initial flows were drilled, and it was generally thought to be a very promising pool. The production of the wells ran down very rapidly, however, and soon ceased. The oil came entirely from the Fifty-foot sand and is said to have been accompanied by varying amounts of salt water. With the exception of the Behling No. 1 well, no records of wells were secured, and only a few of the old holes are located on the map.

Venice oil field.-Oil has been produced in the Venice field since about 1894. The first wells in this field were mainly gas producers from the Fifty-foot sand, though some oil was also found in the same sand. When these wells were deepened to the Fourth sand many of them began producing oil in large quantities. The best well had an initial flow of as much as 100 barrels per hour. The oil comes mainly from the Fourth sand, though an occasional well in the southern part of the field found oil in the Fifth and the Gordon sands. There is a marked increase of oil in the Gordon sand north from Venice. In that direction there is no line of demarcation between the Venice and the McDonald pools, the decrease in the number of Fourth sand wells being as gradual as the increase of oil in the Gordon sand. The production of the wells now range from a fraction of a barrel to a few barrels a day, and many once good oil wells have been exhausted and abandoned.

In this field the Fourth sand shows no salt water. In a few wells small quantities of water have been pumped from the Gordon sand, but at no place does the water appear seriously to affect the flow of oil into wells.

Oil in the Fifth sand of the Canonsburg field appears to pinch out a mile or more south of Venice, and this point is assumed to mark the southern edge of the Venice field. In the same way the northern edge may be assumed to be marked by the disappearance of oil in the Fourth sand. The Gordon pool, however, in that field extends northeast almost unbrokenly to the Moon Run field, a distance of about 9 miles, and embraces the major portion of the famous McDonald field. 
The stratigraphy of the oil sands in the Venice field does not differ materially from that of the Canonsburg field already described. Some variations of importance occur in the porosity of the oil sands, which, because of lack of data, can not be described in detail. It is generally recognized, however, that northward from the Canonsburg field the Fifth sand, though probably considerably thinner in places, is almost, if not always, found in wells drilled to it and is therefore very probably a continuous bed. Its greatest change is probably in quality. In the Canonsburg pool, where the bed is very productive, the pay streak consists of from one to several feet of quartz-pebble conglomerate very open and porous. Traced northward this conglomeratic layer appears to change into a coarse sandstone, which is finer grained at the edge of the pool. What is said of the varying porosity of the Fifth sand is to a greater or less extent true of the other oil-bearing beds, though some of them are not conglomeratic. The productive portions are always found to be softer and apparently more porous than the part not saturated with oil, but at places good pay streaks are reported which contain no oil, gas, or water. The following typical records of wells in this field serve to show changes in thickness of the more important oil sands.

Partial records of deep wells in the Venice field, Cecil Township, Washington County, Pa.

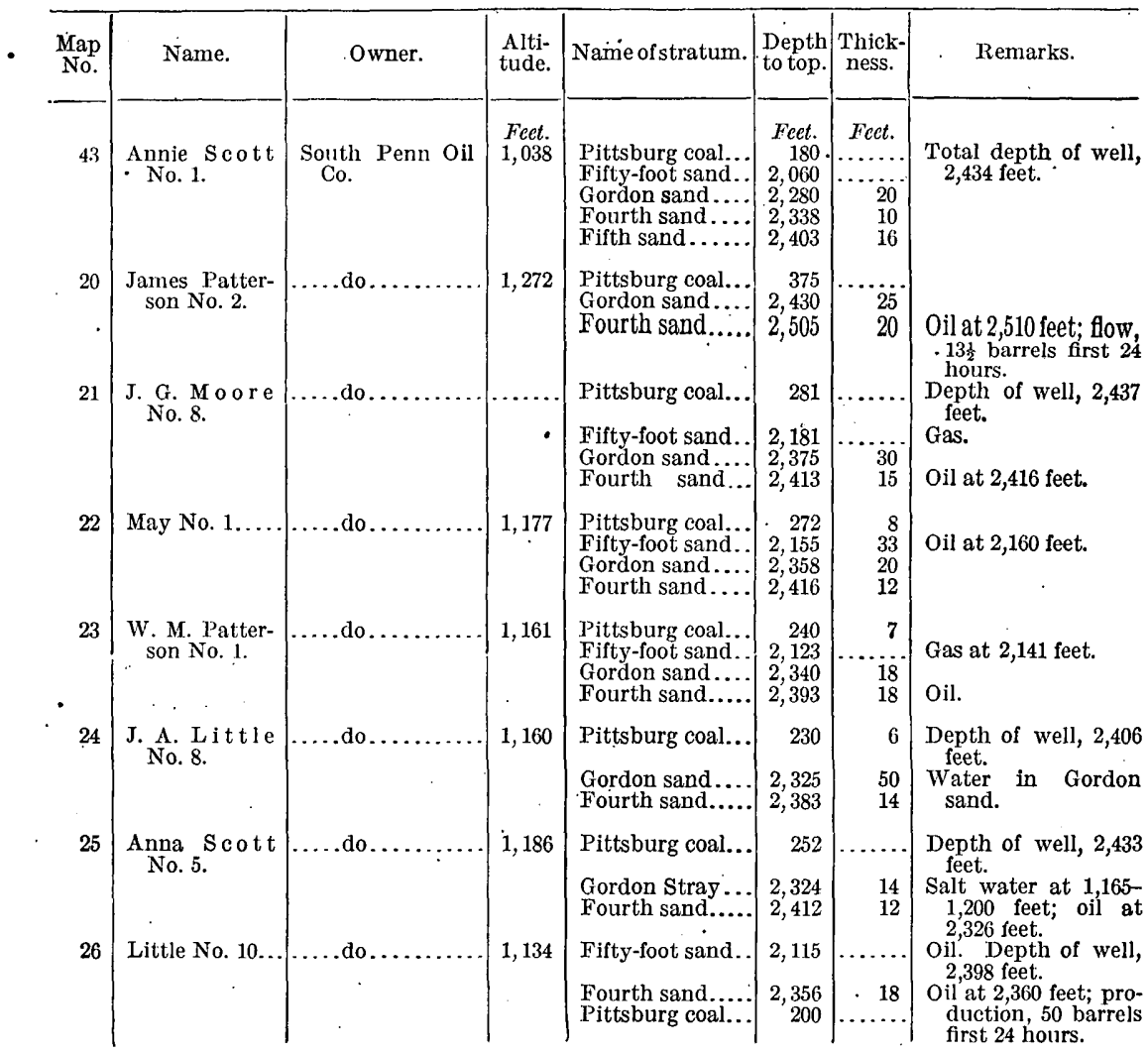


Partial records of deep wells in the Venice field, Cecil Township, Washington County, $P a$.-Continued.

\begin{tabular}{|c|c|c|c|c|c|c|c|}
\hline $\begin{array}{l}\text { Map } \\
\text { No. }\end{array}$ & Name. & Owner. & $\begin{array}{l}\text { Alti- } \\
\text { tude. }\end{array}$ & Name of stratum. & $\begin{array}{l}\text { Depth } \\
\text { to top. }\end{array}$ & $\begin{array}{l}\text { Thick. } \\
\text { ness. }\end{array}$ & Remarks. \\
\hline 27 & Little No. 6... & $\begin{array}{l}\text { South Penn Oil } \\
\text { Co. }\end{array}$ & $\begin{array}{l}\text { Feet. } \\
1,114\end{array}$ & $\begin{array}{l}\text { Pittsburg coal .. } \\
\text { Fifty-foot sand... } \\
\text { Gordon sand.... } \\
\text { Fourth sand..... }\end{array}$ & $\begin{array}{l}\text { Fect. } \\
240 \\
2,143 \\
2.338 \\
2,394\end{array}$ & $\begin{array}{r}\text { Feet. } \\
8 \\
45 \\
17 \\
15\end{array}$ & $\begin{array}{l}\text { Depth of well, } 2,411 \\
\text { feet. } \\
\text { Water at } 2,348 \text { feet. } \\
\text { Oil at } 2,396 \text { feet. }\end{array}$ \\
\hline 28 & $\begin{array}{l}\text { Kelso Bros. } \\
\text { No. } 4 .\end{array}$ & .... do . . . . & 1,167 & $\begin{array}{l}\text { Pittsburg coal... } \\
\text { Gordon sand .... } \\
\text { Fourth sand..... } \\
\text { Fifth sand...... }\end{array}$ & $\begin{array}{r}318 \\
2,386 \\
2,471 \\
\\
2,534\end{array}$ & $\begin{array}{l}50 \\
18 \\
11\end{array}$ & $\begin{array}{l}\text { Depth of well, } 2,565 \\
\text { feet. } \\
\text { Poor; show of oil in } \\
\text { Fourth sand. } \\
\text { Well dry of water. }\end{array}$ \\
\hline 29 & Kelso No. 5... & ....do...... & 1,202 & $\begin{array}{l}\text { Pittsburg coal... } \\
\text { Fourth sand.... } \\
\text { Fifth sand...... }\end{array}$ & $\begin{array}{r}270 \\
2,420 \\
2,490\end{array}$ & $\begin{array}{r}10 \\
10 \\
10\end{array}$ & $\begin{array}{l}\text { Light show of oil at } \\
2,430 \text { feet. } \\
\text { Gas at } 2,497 \text { feet. }\end{array}$ \\
\hline
\end{tabular}

McDonald oil field.-In point of productiveness the McDonald oil field is one of the greatest of southwestern Pennsylvania, and it may well be classed as one of the great fields of the Appalachian region. Development work in this pool was started probably as early as the year 1890, but active work was not begun until the spring of 1891, when several fairly good wells' were secured within the corporation limits of McDonald. These wells were first sunk to the Gordon sand, which flowed oil in some of the best wells at the rate of 100 barrels per hour. When these wells were deepened to the Fifth sand the flow was greatly increased. The excitement which followed was intense. Hundreds of wells were sunk within a few months, and drilling continued at top speed for more than a year. The production in this field rose from a few barrels per day in March, 1891, to a maximum of more than 83,000 barrels per day in November of the same year.

Only a part of the southern end of this field lies in Cecil Township, the principal part being in North Fayette, South Fayette, Collier, and Robinson townships. This field was developed from several foci, and different parts of it were given names while being developed. These pools apparently form a continuous belt of oil, with perhaps a few narrow breaks, from Canonsburg to. beyond Ohio River at Neville Island. These names will be used in this report, and the name McDonald applied to only that portion of the field which was developed or outlined shortly after the great excitement of 1891 .

In that portion of the field situated in Cecil Township the principal part of the oil has been obtained from the Gordon sand, though the Fifth sand has furnished a large amount from the vicinity of McDonald, and some oil with considerable gas has been found in the Fifty-foot sand. Although a number of these wells have produced more than 1,000 barrels per day from the Gordon sand, many of them have produced from the same sand less than 50 barrels per day at their best. The total production from the Gordon sand is, however, very 
great, since most of the wells after 18 years of constant pumping are still yielding from 1 to 10 barrels per day.

A few records, which are fairly typical of a large number of the wells in this portion of the McDonald field, are given as follows:

Partial records of deep wells in the McDonald field, in Cecil Township, Washington County, $P a$.

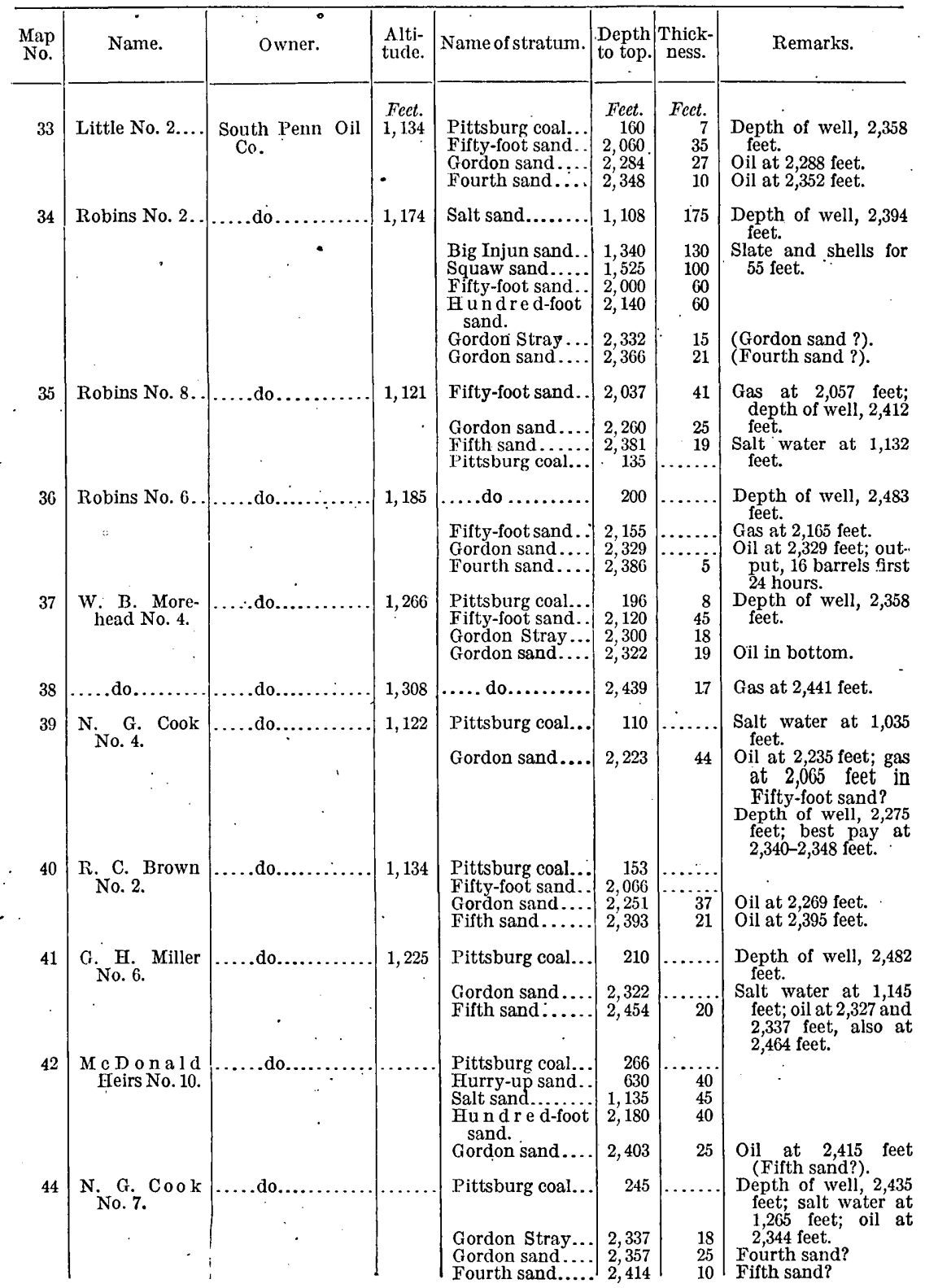


Partial records of deep wells in the McDonald field, in Cecil Township, Washington County, Pa.-Continued.

\begin{tabular}{|c|c|c|c|c|c|c|c|}
\hline $\begin{array}{l}\text { Map } \\
\text { No. }\end{array}$ & Name. & Owner. & $\begin{array}{l}\text { Alti- } \\
\text { tude. }\end{array}$ & Name of stratum. & $\begin{array}{l}\text { Depth } \\
\text { to top. }\end{array}$ & $\begin{array}{l}\text { Thick- } \\
\text { ness. }\end{array}$ & Remarks. \\
\hline 45 & $\begin{array}{l}\text { M c Donald } \\
\text { Heirs No. } 12 .\end{array}$ & $\begin{array}{l}\text { South Penn Oil } \\
\text { Co. } \\
\text {. }\end{array}$ & Feet. & $\begin{array}{l}\text { Pittsburg coal... } \\
\text { Hurry-up sand.. } \\
\text { Salt sand........ } \\
\text { Gordon sand.... } \\
\text { Fifth sand ...... }\end{array}$ & $\begin{array}{r}\text { Feet. } \\
180 \\
625 \\
1,065 \\
2,318 \\
2,437\end{array}$ & $\begin{array}{l}\text { Feet. } \\
\cdots \cdots \\
50 \\
\cdots \\
22 \\
10\end{array}$ & $\begin{array}{l}\text { Depth of well, } 2,459 \\
\text { feet. }\end{array}$ \\
\hline 46 & $\begin{array}{l}\text { Ed. McDonald } \\
\text { No. } 21 .\end{array}$ & .....do...... & 1,132 & $\begin{array}{l}\text { Pittṣburg coal... } \\
\text { Gordon sand.... } \\
\text { Firth sand..... }\end{array}$ & $\begin{array}{c}60 \\
\cdot \\
2,200 \\
2,325\end{array}$ & $\begin{array}{l}23 \\
17\end{array}$ & $\begin{array}{l}\text { Depth of well, } 2,355 \\
\text { feet; salt water at } \\
410 \text { feet; oil at } 2,223 \\
\text { feet. } \\
\text { Oil at } 2,235 \text { feet. }\end{array}$ \\
\hline
\end{tabular}

From these records it will be seen that the Gordon sand in this portion of Cecil Township has a thickness ranging from 15 to 44 feet, with an average of about 25 feet. The Fifth sand is thinner, ranging from 10 to 25 feet, with an average of about 16 feet. It will also be seen that oil was found in the sands at various distances from the top, with a general average of 12 feet and 8 feet, respectively, for the Gordon and the Fifth sands. These records to some extent also reveal the fact that these sands thicken northward from the southern edge of the field. A somewhat unusual condition is revealed by the records of Nos. 37 and 38. The former is an oil well in the Gordon sand and the latter is shown to be a gas well in the same sand at a lower level.

This discussion of the McDonald oil field will be continued under North Fayette and South Fayette townships, Allegheny County.

\section{NORTH FAYETTE AND SOUTH FAYETTE TOWNSHIPS, ALLEGHENY COUNTY.}

McDonald oil field.--The center of the McDonald oil field is near the border line between North Fayette and South Fayette townships in the vicinity of McDonald. The area of greatest production was probably on a line extending northeast from McDonald, and included the Mathews, Gamble, Mevey, McMurry, Robb, Sturgeon, and Elliott farms, as well as a number of others in that vicinity. It was the production from a number of large wells on these farms that ran the daily output of the McDonald field up to a maximum of about 83,000 barrels per day on November 5, 1891. A single well on the Mathews farm is said to have reached a maximum flow of 730 barrels per hour, and is said to have been yielding 15 barrels per day in 1907, after producing a total of more than 2,000,000 barrels. Another well on the Mevey farm flowed more than 100,000 barrels. in 11 days. A large number of wells in this vicinity came in at more than 200 barrels per hour. During the months of October and November, 1891, 
this field produced more than $3,700,000$ barrels of oil. Its production decreased from an average of more than 60,000 barrels per diay during those two months to a production of about 18,000 barrels per day at the end of 1892, and 12,000 barrels per day at the end of 1893 . From this time forward the decrease was less rapid, the production being augmented from time to time by new extensions of the field. The following table shows the approximate production of the McDonald oil field by years:

Production a of oil from the McDonald field, Washington and Allegheny counties, Pa., 1890-1909.

\begin{tabular}{|c|c|c|c|}
\hline 1890. & $\begin{array}{l}\text { Barrels. } \\
35,000\end{array}$ & 1901. & $\begin{array}{r}\text { Barrels. } \\
925,000\end{array}$ \\
\hline 1891. & $7,100,000$ & $1902 \ldots \ldots \ldots \ldots \ldots \ldots$ & 775,000 \\
\hline 1892. & $8,400,000$ & $1903 \ldots \ldots \ldots \ldots$ & 650,000 \\
\hline 1893. & $5,300,000$ & $1904 \ldots$ & 575,000 \\
\hline 1894. & $4,200,000$ & $1905 \ldots \ldots \ldots \ldots \ldots$ & 525,000 \\
\hline 1895. & $3,300,000$ & $1906 \ldots \ldots \ldots \ldots \ldots$ & 525,000 \\
\hline 1896. & $2,600,000$ & $1907 \ldots$ & 575,000 \\
\hline 1897. & $1,950,000$ & $1908 \ldots \ldots \ldots$ & 490,000 \\
\hline 1898. & $1,500,000$ & 1909 (first half). . . & 235,000 \\
\hline $\begin{array}{l}1899 . \\
1900 .\end{array}$ & $\begin{array}{l}1,400,000 \\
1,075,000\end{array}$ & & \\
\hline
\end{tabular}

The decrease in production of this field is shown graphically in figure 2 .

Most of the oil in the McDonald field proper came from the Gordon and the Fifth sands, though the Fifty-foot and the Fourth sands furnished large quantities. In many of the great gushers the Gordon sand first began production at from 50 to 200 barrels per hour, which was increased to from 100 to more than 700 barrels per hour by subsequent drilling to the Fifth sand. This ratio does not hold, however, for the whole field. In many areas one or the other of these sands was entirely barren, the other producing all the oil. Also in a few places within the productive territory barren spots occur in both sands. In such cases the sands are reported as being hard and close without the open pebbly pay streak of the oil-bearing areas.

South of Sturgeon an area of several hundred acres was found to be unproductive, both the Gordon and the Fifth sands being of poor quality. Farther to the south both sands apparently assume their normal thickness and porosity in the pools extending from the county line south of McDonald east to the vicinity of Bridgeville, but in this region neither of them furnishes much oil. Northwest from the McDonald pool the Gordon sand appears to keep almost its normal thickness, but is lacking in porosity. The Fifth sand seems to pinch out entirely just beyond the limits of the field, and thence northwestward is reported in comparatively few wells, where it occurs as thin close sand, or as "shale and shells."

$a$ This production includes also all or a portion of that from the Venice, Cecil, Cuddy, Lickskillet Hopper, and MeCurdy fields as described in this bulletin. 


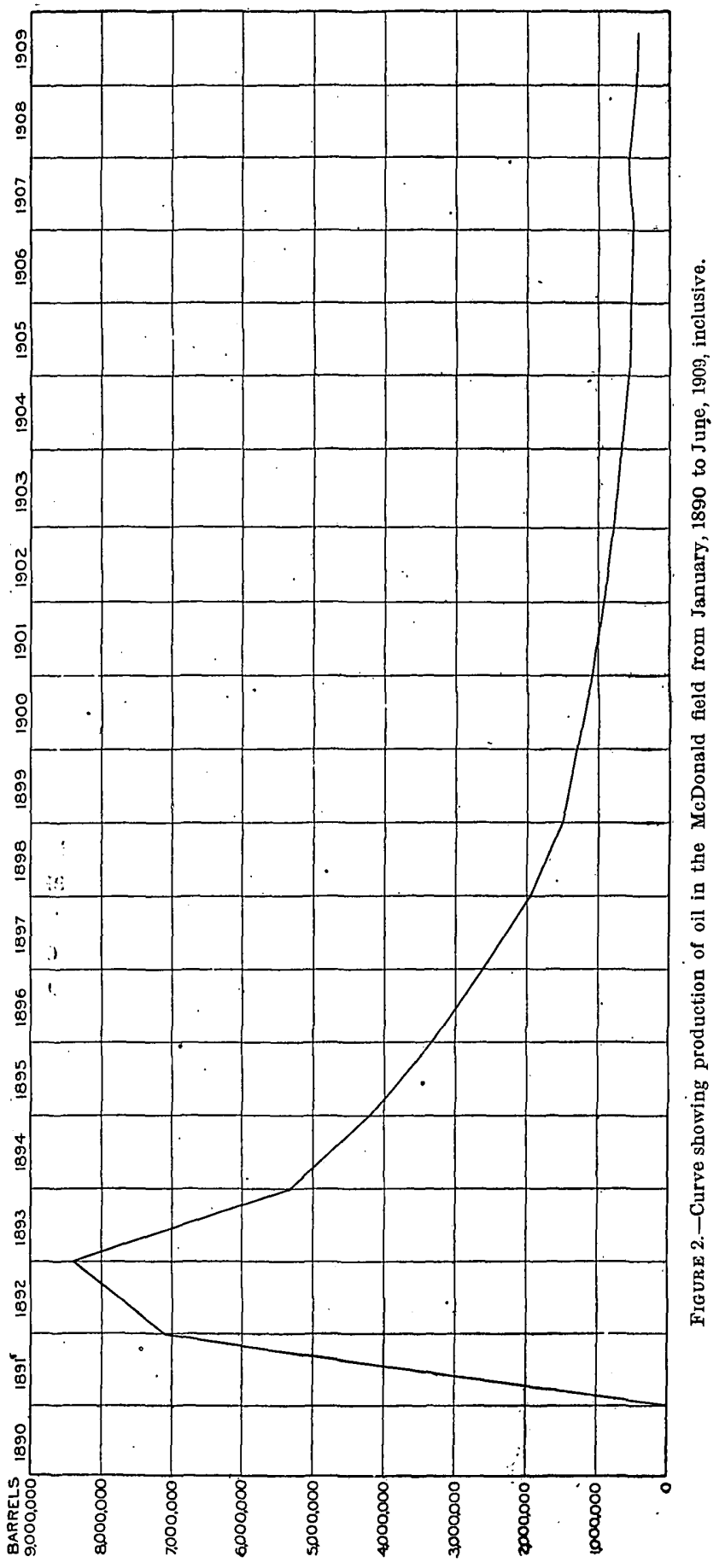


The following records of wells in the McDonald field give a fair idea of differences in the stratigraphy of the oil-bearing sands and of some of the closely associated beds:

Partial records of deep wells in the McDonald field, Allegheny County, Pa.

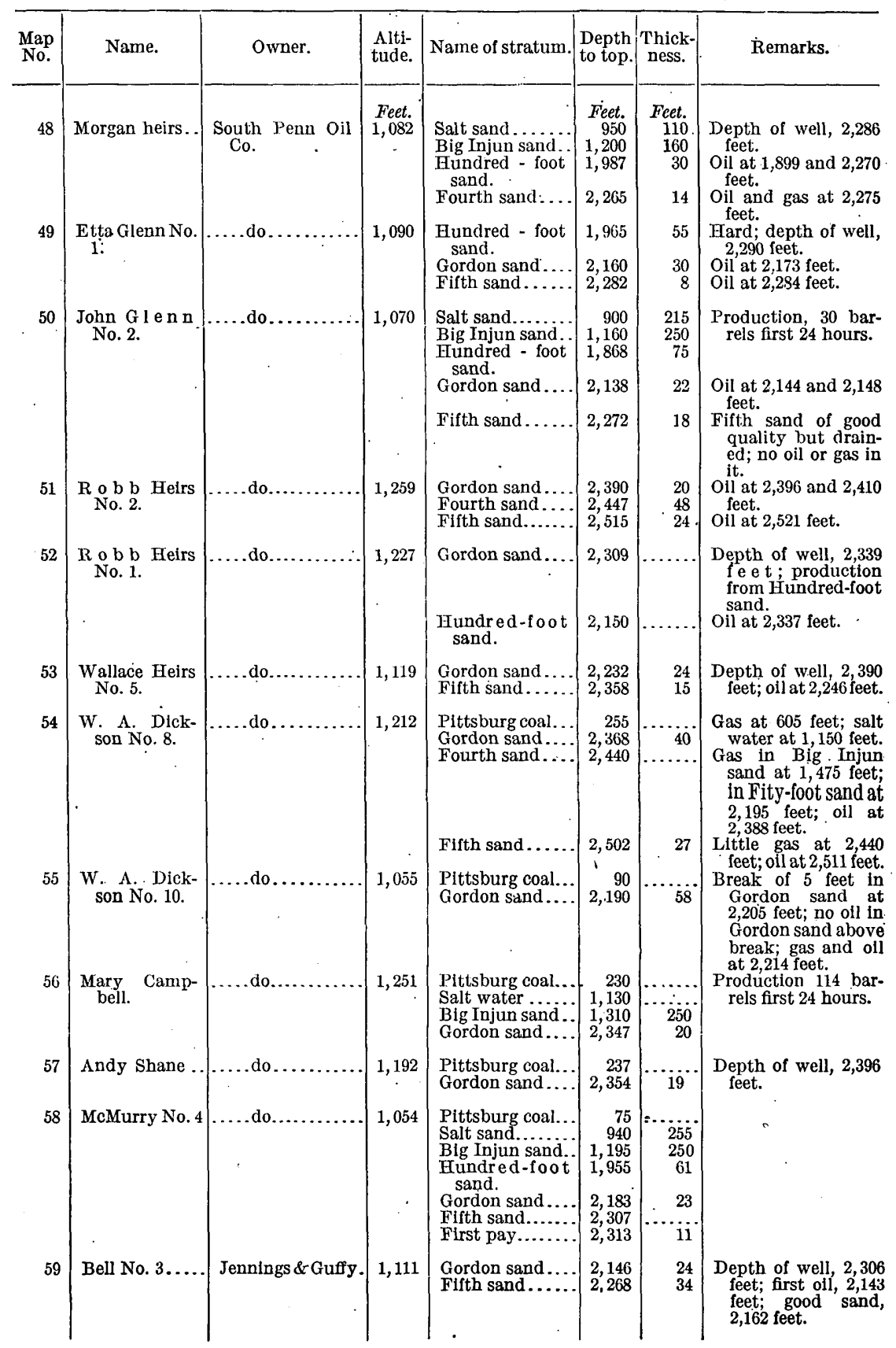


Partial records of deep wells in the McDonald field, Allegheny County, Pa.-Continued.

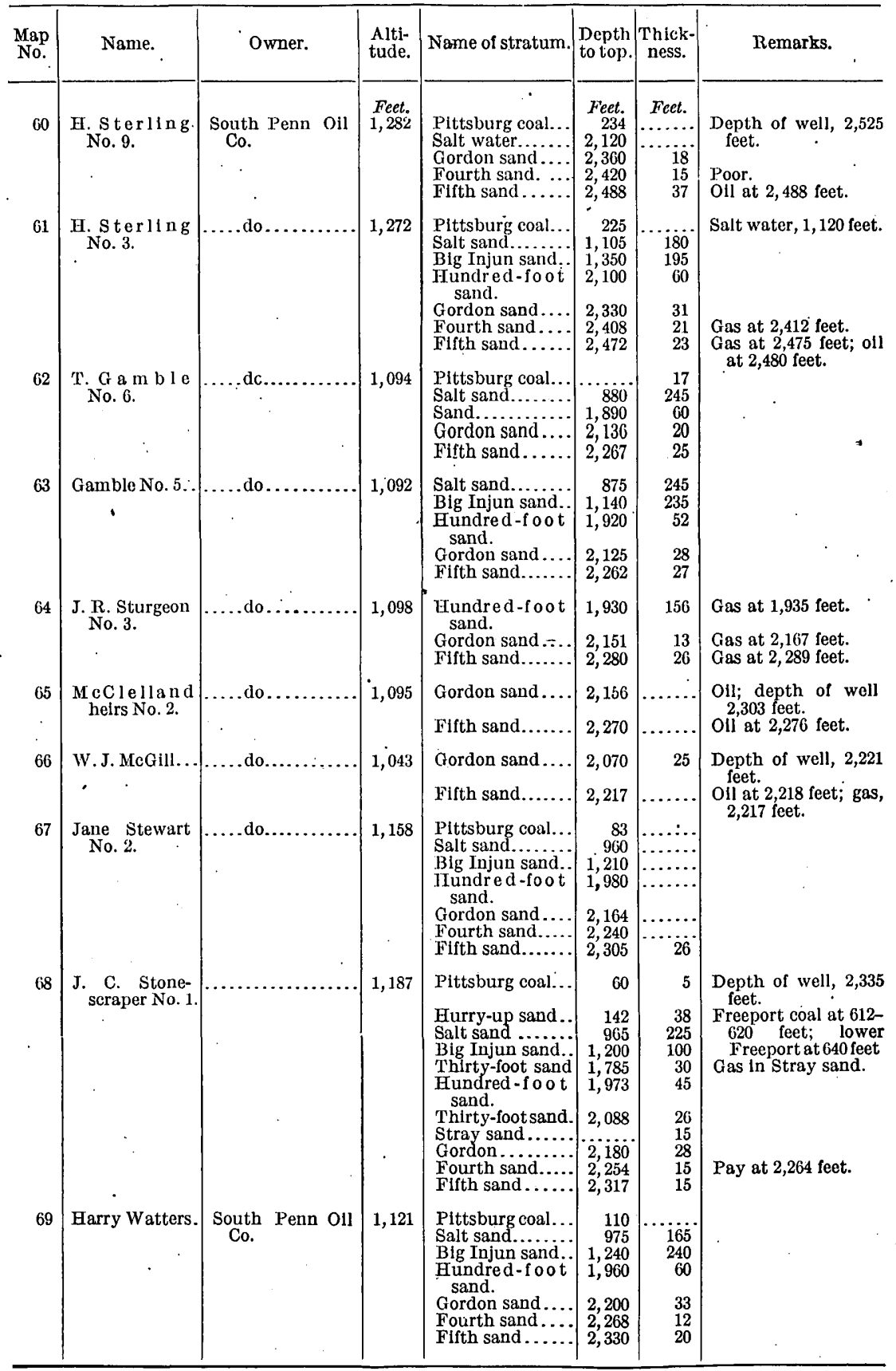


From these records it will be seen that the thickness of the Gordon sand ranges from 13 to 58 feet, with an average of about 26 feet, whereas the Fifth sand is from 8 to 37 feet thick, with an average of about 23 feet. These averages are probably fairly close for the productive portions of these sands throughout the entire field. The maximum of 58 feet for the Gordon sand is unusual. This maximum is reported in the W. A. Dickson well No. 10 (No. 55 on map) in which a "break" of 5 feet (see table) occurs in this sand, which is probably the division between the Gordon Stray and the Gordon, thereby reducing the latter to a thickness of 38 feet. In the most productive portions of the field these sands appear to be somewhat above their average thickness but not abnormally so. The greatest difference is not in the thickness but in the character of the sands from place to place. In the most productive portions of the field the entire sand appears to be made up of very coarse sand, containing a relatively large amount of small quartz pebbles very poorly cemented together. In the less-productive spots the sands are invariably finer 'grained and as a rule contain only thin streaks of pebbly material. In such areas the oil was frequently encountered after drilling several feet into the sand: From the records given in the table it will be seen that the position of the pay streak in the Gordon sand varied in different wells from the top of the sand down to a depth of 28 feet with an average distance of 13 feet 6 inches from the top. The maximum distance from the top of the Fifth sand to the pay streak is 9 feet, with 4 feet as the average.

The theoretical value of these data lies in the fact that oil and even gas are not always found in the top of the sand. There is ample evidence that in many cases a close fine-grained sand may be penetrated by a well to a depth of several feet with little or no showing of oil, but when a more porous streak is encountered oil will be produced with a pressure sufficient to cause it to flow from the mouth of the well. The same is also true of many gas wells, though in most cases where the main flow of gas comes from a pay streak low in the sand a small quantity of gas is found in the same sand above the pay streak. When it is remembered that even the closest-grained unaltered sandstones of this type contain at least from 4 to 10 per cent of pore space, the difficulty of accounting for the phenomena becomes apparent. The subject can not be dismissed by considering the rocks to be impervious, because the stubborn fact remains that no sandstone of this type has ever been found to be impervious. In reality it contains holes that aggregate from 5 to 10 or more square inches for every square foot of surface. Some of these facts are not clearly explained in theories advanced to account for the accumulation of oil and gas into pools. 
Neither the Gordon nor the Fifth sand has been found to contain very appreciable amounts of salt water in that portion of the McDonald field covered by the records published above. In a few wells small quantities of salt water are said to have been found in the Gordon sand. In most cases this water appeared in wells approaching exhaustion, and at most amounted to only a few barrels per day. So far as could be learned by diligent inquiry, the oil pool occurring in the Fifth sand in that portion of the McDonald field embraced by Cecil and North and South Fayette townships shows no salt water with the oil. The principal water-bearing sand of this area is the Salt sand (one of the sandstones of the Pottsville formation); in many places also the Big Injun and less often the Hundred-foot carry more or less salt water. Below the Fifth sand no salt water has been found in this region.

Hopper oil pool.-The name "Hopper" is used to designate a small pool of oil in the Fourth sand which is situated about one-half mile northeast of Reissing, in South Fayette Township. The exact outline of the pool can not be easily defined, since it appears to extend as a more or less unbroken pool southwest to the Fourth sand pool of the Venice field, and north until it apparently merges with the Gordon and Fifth sand pools of the McDonald field. Eastward the extent of this pool can not be outlined by the writer because of lack of reliable logs of wells. It is known, however, to extend as far east as the B. Morgan No. 7 well (No. 74 on map), which found oil in both the Fourth and the Hundred-foot sands.

In the vicinity of wells Nos. 71 and 72 small pools of oil have been encountered in both the Gordon and the Fifth sands, though the main supply was furnished by the Fourth sand.

The pioneer well in this pool (No. 77) was drilled on the Joseph Campbell farm by C. D. Robbins, of Washington, Pa., long before the McDonald field and the fields in Cecil Township were discovered. This well struck oil and is reported to have produced more than 200 barrels before being abandoned for want of a pipe line to transport the oil. Mr. Robbins is said to have held leases on an immense tract of land extending from Ohio River southwest to Washington, $\mathrm{Pa}$., which embraced most of the great oil pools in this vicinity. $\mathrm{He}$ drilled a number of wells on this tract, but was signally unfortunate in missing the productive portions, frequently by the narrowest margin, as indicated by the position of this well on the Campbell farm. It is now known that if this well had been located a thousand feet farther north, east, or west, it would have flowed probably several hundred barrels per day, and would have precipitated the McDonald and Venice oil excitements years before they occurred.

$83448^{\circ}-$ Bull. $456-11-4$ 
In this field the Fourth sand has furnished a number of flowing wells, some of which are said to have had an initial production of from 50 to 100 barrels per hour. The Gordon and the Fifth sands have also furnished a few flowing wells, but of relatively small capacity.

The field was developed in the years 1886-1899, and on the whole the wells proved to be short lived. After three or four years many of them were producing only a few barrels per day. The field is now practically exhausted and many wells have already been abandoned.

An examination of the map Plate IV will show that the Hopper field extends along a narrow, gently sloping structural terrace on the western limb of the Nineveh syncline, and that structurally, as well as stratigraphically, it is closely related to the Fourth sand pool at Venice, and may, in fact, be a part of it.

The Gordon and the Fourth sands in this field show a little water in a few places, but the amount produced with the oil in any well is very small. The Fifth sand shows no water.

Lickskillet oil and gas field.-The name "Lickskillet" is applied to the producing area situated north of Cuddy, Morgan, and Sygan, and is intended to embrace the oil pool in the Hundred-foot sand in the vicinity of the last-named town. This field extends east from well No. 74 to the edge of the productive territory in the vicinity of Sygan and north to well No. 75. It is said that wells which once furnished oil in the Hundred-foot sand have later been drilled deeper and have found gas in the Fourth or Fifth sands. Very little data relative to the production of gas in this area is available.

The name "Hundred-foot" is here evidently applied only to the lower or Fifty-foot member of the true Hundred-foot sand of the oil fields farther north in Butler and Armstrong counties. The socalled Hundred-foot sand here has an average thickness of 20 to 30 feet, and in but a single instance is it reported to be more than 60 feet thick. The Fourth, the Fifth, and the Gordon sands are probably a little below the average thickness as given above for the McDonald pool. All the sands, however, are far more uniform in thickness than in porosity; the pay streaks in them appear to be very irregular.

Attention is especially called to the fact that the Fourth and the Fifth sands carry considerable gas in wells in the vicinity of Nos. 73 and 74, and eastward from them along the southern margin of the field. It will be noticed that this is structurally the lowest part of the sands in the Lickskillet and the Hopper fields, and that this occurrence, so far as structure alone is considered, does not seem to agree with the anticlinal theory of oil and gas accumulation. It is not, however, a good example, since the extent, direction, and thickness of the pay streaks in these sands are not sufficiently well known to admit of a clear and definite statement of all the conditions which, according to that theory, might be responsible for these accumulations. 
The following table of well records, though very imperfect, may prove of some stratigraphic value:

Partial records of deep wells in the Lickskillet and Hopper oil and gas fields, South Fayette Township, Allegheny County, Pa.

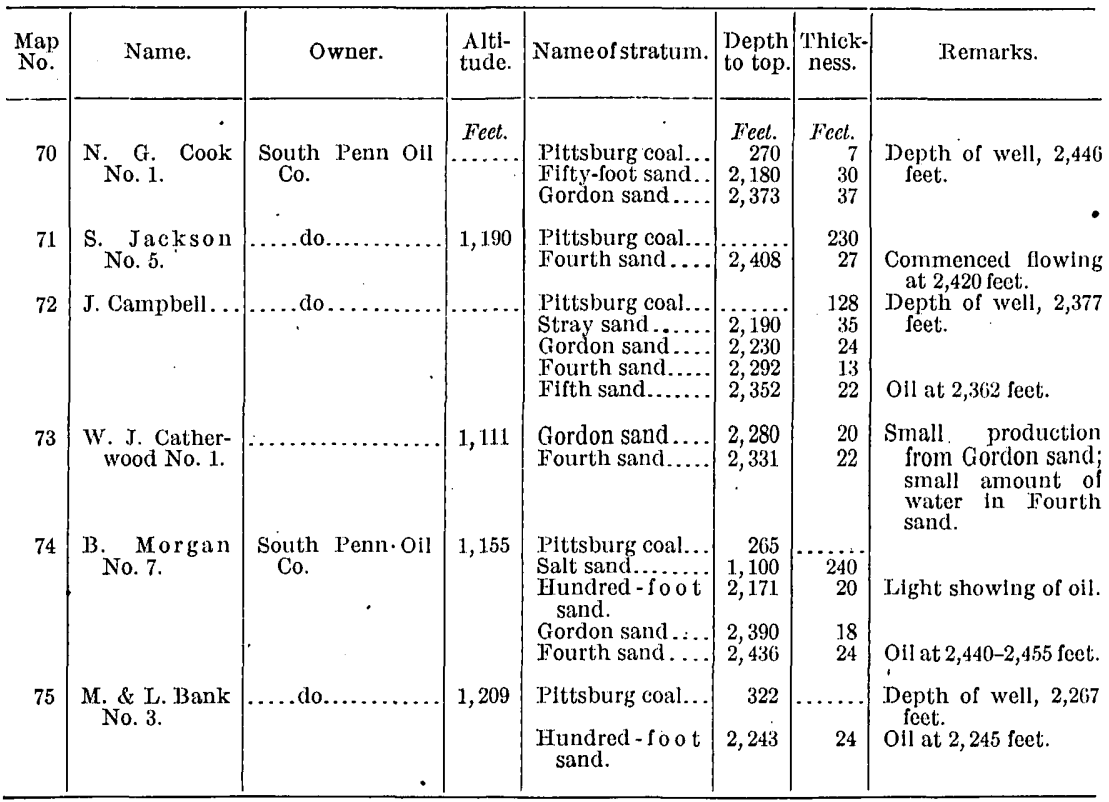

Cuddy oil and gas field.-The oil pool in the Hundred-foot sand in the Lickskillet field appears to have a southwestern extension, which connects it more or less closely with a small oil pool in this sand lying a short distance south of Cuddy post office. Most of the oil from this field has come from the pool in the Hundred-foot sand, but the Fourth sand has produced both oil and gas in a few wells and the Fifth sand has furnished considerable quantities of gas. The Gordon sand appears to be so thin and of such inferior quality in this field that no mention is made of it in many of the records. In wells Nos. 192 and 196 this sand is accorded a thickness of 32 feet and 70 feet, respectively, but in the latter well the intervals between the Gordon sand and the Fourth and Fifth sands and the Pittsburg coal indicate strongly that the true Gordon sand is probably not more than 22 feet thick, the upper portion probably being equivalent to the Gordon Stray sand. In the W. S. Hickman No. 2 well the Gordon sand is reported to be only 10 feet thick, and in others it appears to be represented by only a few feet of "shale and shells."

The Fourth sand in this pool seems to be normal in thickness and quality, being from 10 feet to 30 feet thick, with an average of about 20 feet. The oil and gas "pays" in this sand are found from the top to 25 feet below the top, but in no record is the thickness of the pay streak given. The Fifth sand has about the same thickness as the 
Fourth sand and its pay streak appears to be equally as erratic. In well No. 191, on the W. S. Hickman farm, the total thickness of the Hundred-foot sand as given in the well record is 12 feet, with the pay streak 5 feet from the top. This sand is the Gantz, or the upper member of the Hundred-foot, and does not represent the entire bed, the Fifty-foot, or lower member, probably being present as sandy shale alternating with thin sandstone "shells." In well No. 193 the Hundred-foot is reported to be 18 feet thick, as against 11 feet in No. 194. In well No. 195 this sand is called the Fifty-foot and is 27 feet thick, and in wells Nos. 196, 197, 198, and 199 it is, respectively, $13,10,8$, and 12 feet thick. In most of these wells a thin pay streak containing oil occurs near the middle of the sand.

The maximum daily production from the best wells in this pool was not large, being probably less than 100 barrels a day. Salt water is found in the Hundred-foot sand in a number of wells, and it is thought that one or two wells in the Fourth sand have also shown small quantities of salt water. The Gordon and the Fifth sands are reported dry. The great salt-water sands of this vicinity, as elsewhere in the Carnegie quadrangle, are the Big Injun and the-Salt sands. This water is always under sufficient head to fill up several hundred feet in the well and in some cases to flow from the well mouth. It is usually cased off with $5 \frac{5}{8}$-inch casing at depths of 1,250 to 1,400 feet.

The following are partial records of wells in the Cuddy field:

Partial records of deep wells in Cuddy oil and gas field, South Fayette Township, Allegheny County, Pa.

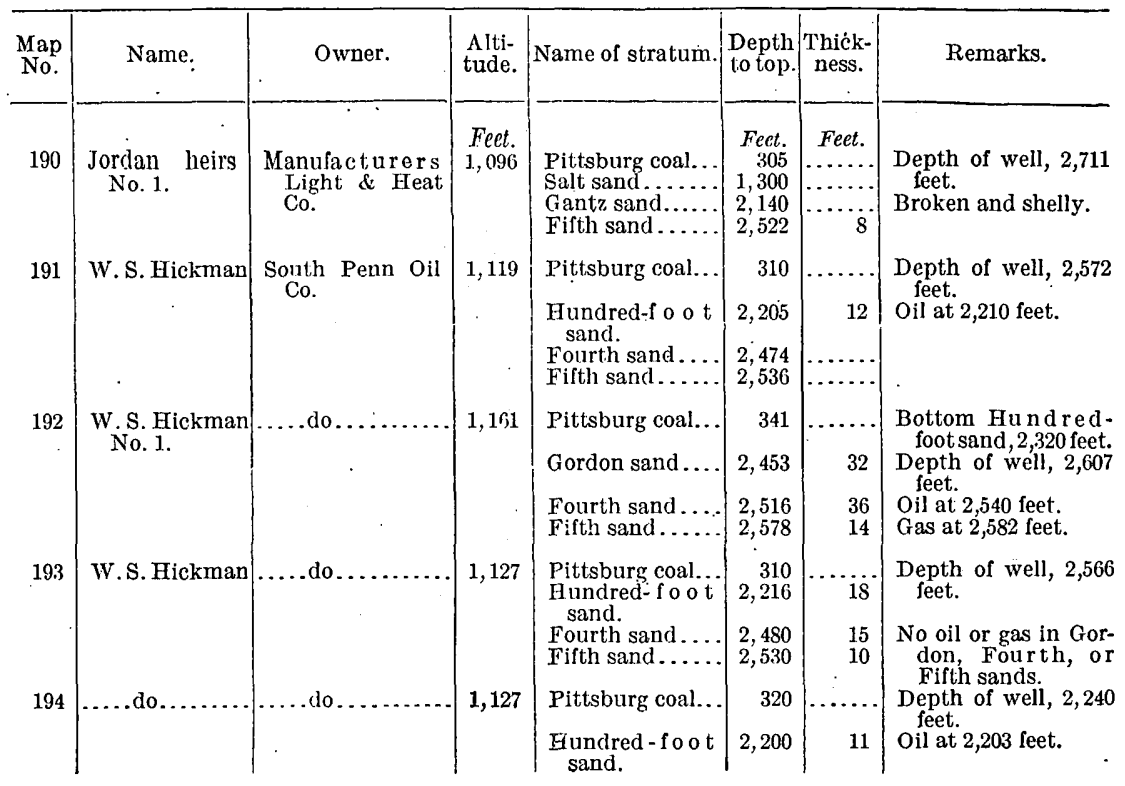


Partial records of deep wells in Cuddy oil and gas field, South Fayetie Township, Allegheny County, Pa.-Continued.

\begin{tabular}{|c|c|c|c|c|c|c|c|}
\hline $\begin{array}{l}\text { Map } \\
\text { No. }\end{array}$ & Name. & Owner. & $\begin{array}{l}\text { Alti- } \\
\text { tude. }\end{array}$ & Name of stratum. & $\begin{array}{l}\text { Depth } \\
\text { to top. }\end{array}$ & $\begin{array}{l}\text { Thick- } \\
\text { ness. }\end{array}$ & Remarks. \\
\hline 195 & $\begin{array}{l}\text { W. J. Wallace } \\
\text { No. } 1 .\end{array}$ & $\begin{array}{l}\text { South Penn Oil } \\
\text { Co. }\end{array}$ & $\begin{array}{l}\text { Feet. } \\
1,111\end{array}$ & $\begin{array}{l}\text { Pittsburg coal... } \\
\text { Fifty-foot sand.. } \\
\text { Fourth sand.... }\end{array}$ & $\begin{array}{r}\text { Feet. } \\
320 \\
2,292 \\
2,481\end{array}$ & $\begin{array}{r}\text { Fect. } \\
27 \\
15\end{array}$ & First pay, oil, at \\
\hline 196 & $\begin{array}{l}\text { W. J. Wallace } \\
\text { No. } 2 .\end{array}$ & .....do.. & 1,117 & $\begin{array}{l}\text { Pittsburg coal... } \\
\text { Fifty-foot sand.. } \\
\text { Gordon sand .... } \\
\text { Fourth sand.... } \\
\text { Fifth sand...... }\end{array}$ & $\begin{array}{r}210 \\
2,210 \\
2,369 \\
2,474 \\
2,522\end{array}$ & $\begin{array}{l}13 \\
70 \\
24 \\
30\end{array}$ & $\begin{array}{l}\text { Oil. } \\
\text { Gas at } 2,546 \text { feet. }\end{array}$ \\
\hline 197 & W.S. Hickman & ....do..... & 1,117 & $\begin{array}{l}\text { Pittsburg coal... } \\
\text { Hundred - f o o.t } \\
\text { sand. }\end{array}$ & $\begin{array}{r}290 \\
2,186\end{array}$ & $\begin{array}{c}\cdots \\
10\end{array}$ & $\begin{array}{l}\text { Depth of well, } 2,206 \\
\text { feet. } \\
\text { Natural flow, } 30 \text { bar- } \\
\text { rels per day. }\end{array}$ \\
\hline 198 & $\begin{array}{l}\text { W. s. Wallace } \\
\text { No. }\end{array}$ & ....do.. & 1,081 & .... do do......... & 2,165 & 8 & Oil. \\
\hline 199 & $\begin{array}{l}\text { W.S. Wallace } \\
\text { No. } 3 \text {. } \\
\text { W.S. Hickman }\end{array}$ & .....do... & 1,113 & $\begin{array}{l}\ldots . . \text { do ........... } \\
\text { Pittsburg coal... } \\
\text { Fundred - f o o t } \\
\text { sand. } \\
\text { Gordon sand.... } \\
\text { Fourth sand.... } \\
\text { Fifth sand...... }\end{array}$ & $\begin{array}{r}2,201 \\
320 \\
2,210 \\
2,438 \\
2,493 \\
2,552\end{array}$ & $\begin{array}{l}\cdots \\
20 \\
10 \\
10 \\
10\end{array}$ & $\begin{array}{l}\text { Do. } \\
\text { Depth of well, } 2,579 \\
\text { feet. } \\
\text { Oil at } 2,217 \text { feet. } \\
\text { Gas at } 2,556 \text { feet. }\end{array}$ \\
\hline
\end{tabular}

Northwest of the McDonald oil field, in North Fayette Township, a barren tract from one-half mile to 3 miles wide extends from the western edge of the quadrangle northeast to the northern boundary in the vicinity of Ewings Mill. In this area oil and gas in paying quantities have been found only in very small pools of only a few wells each. Data relative to the condition of the various sands are very scarce, since comparatively few wells have been drilled, and only a small percentage of the records of those drilled has been preserved.

In the vicinity of well No. 80 , on the farm of the Dixon heirs the Gordon, the Fourth, and the Fifth sands have supplied 3 or 4 wells with gas in considerable quantities, with a closed pressure of about 600 pounds per square inch. The record of well No. 80 gives the Gordon sand a thickness of 22 feet, which is about the average. From information collected from drillers in this part of the township the sands appear as a whole to be much thinner and to have more erratic pay streaks than farther south. This is especially true of the Fifth sand, which pinches out completely at many points northwest of the McDonald pool. This sand is found at a number of places farther northwest, but it evidently exists as a horizon of irregular lenses rather than as a continuous bed. The Fourth sand in general closely resembles the Fifth in the manner of its distribution, though as a whole it is probably more uniform in thickness and texture. The Gordon sand is by far the most uniform in thickness and texture of these three great oil-bearing beds. In few places have drillers failed to find at least a few feet of sandstone at this horizon; but the sand shows considerable variation both in thickness and in quality. 
The Nineveh Thirty-foot and the Hundred-foot sands show a tendency to thicken going northwest from the McDonald field. This is especially true of the former, which becomes the principal oil-bearing bed in the Imperial oil and gas field. In this township the Nineveh Thirty-foot sand shows no water. The Hundred-foot sand is water bearing, however, in a number of wells. In well No. 80 the $4 \frac{7}{8}$-inch casing evidently shuts off the water from the Hundred-foot sand at 1,960 feet. In the oil pool at well No. 86 the Hundred-foot sand produces salt water with the oil. At many places throughout this area drillers report dry wells in the Hundred-foot sand in close proximity to others from which salt water was obtained. The percentage of wells not containing salt water in this sand appears to decrease materially going north. In this portion of North Fayette Township the Gordon, the Fourth, and the Fifth sands are seldom, if ever, water bearing, though the Gordon is known to contain a copious supply of salt water in the Moon and the Coraopolis fields, at and near the northwest corner of the quadrangle.

Imperial oil and gas field.-The Imperial oil and gas field occupies an area including the northern edge of North Fayette Township and the southern parts of Finley and Moon townships. In that portion of the field lying within North Fayette Township most of the oil is found in the Nineveh Thirty-foot sand, though a small quantity of oil in a few scattered wells comes from the Hundred-foot sand and some gas from the Gordon sand. The Nineveh Thirty-foot sand has furnished no large gushers in this field. Few wells in it have produced more than 100 barrels per day, and the average initial production is far less than that, being probably less than 25 barrels per day. This field has been developing since about the year 1898, though many of the wells in the southwestern part are much more recent. At the time of the writer's last visit, in December, 1907, the field was being extended slowly southwest, beyond the western border of the quadrangle. At the extreme southwest end of this field four wells on the Nancy Crooks farm illustrate the variations to be found in the water conditions of the Hundred-foot sand; in two wells salt water from this sand rose almost to the top, filling the holes for more than 1,500 feet; of two adjoining wells, not over 400 feet away, one had a small showing of water in the Hundred-foot sand and the other had no water at all, though the quality of the sand seems to be practically the same in all the wells, and there seems to be little reason to doubt that the sand is continuous between the wells, since it is always found in wells drilled to that horizon. In a few wells of this portion of the Imperial oil field the Hundred-foot sand is oil and gas bearing.

The following table of records of wells in the northern part of North Fayette Township gives a fair idea of the position and relative thickness of the oil sands: 
Partial records of deep wells in the northern part of North Fayelle Township, Allegheny County, $P a$.

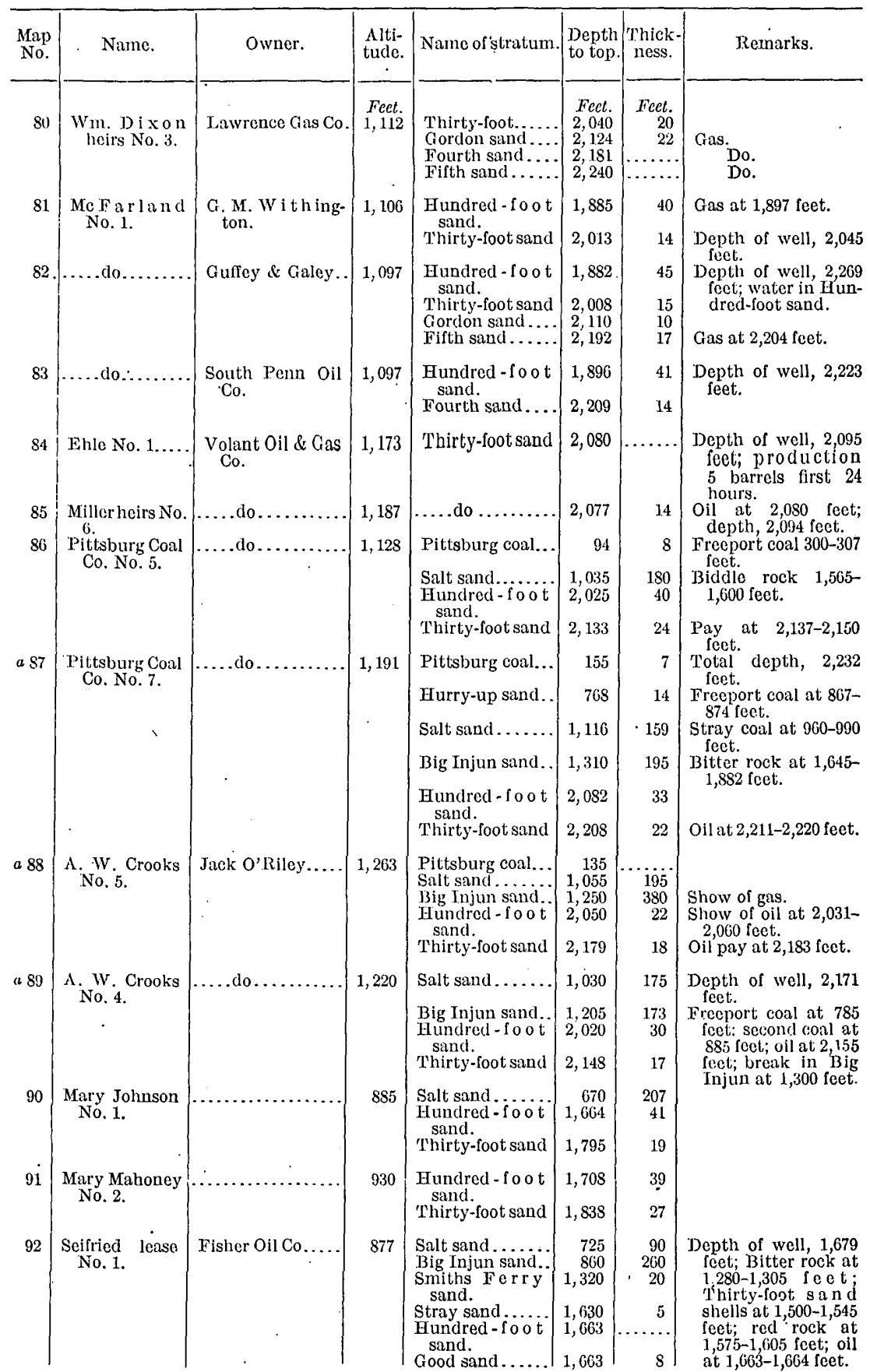

$a$ Wells 87,88 , and 89 are off the western margin of the quadrangle southwest of No. 86 . 
Partial records of deep wells in the northern part of North Fayette Township, Allegheny County, Pa.-Continued.

\begin{tabular}{|c|c|c|c|c|c|c|c|}
\hline $\begin{array}{l}\text { Map } \\
\text { No. }\end{array}$ & Name. & Owner. & $\begin{array}{l}\text { Alti- } \\
\text { tude. }\end{array}$ & Name of stratum. & $\begin{array}{l}\text { Depth } \\
\text { to top. }\end{array}$ & $\begin{array}{l}\text { Thick- } \\
\text { ness. }\end{array}$ & Remarks. \\
\hline 93 & $\begin{array}{l}\text { Troutman No. } \\
1 \text { (formerly } \\
\text { Stewart No. } \\
\text { 1). }\end{array}$ & & $\begin{array}{r}\text { Fect. } \\
890\end{array}$ & $\begin{array}{l}\text { Hurry-up sand.. } \\
\text { Salt sand....... } \\
\text { Gantz.sand..... } \\
\text { Hundred - f o o t } \\
\text { sand. } \\
\text { Thirty-foot sand } \\
\text { Gas sand......... } \\
\text { Gordon sand.... }\end{array}$ & $\begin{array}{r}\text { Feet. } \\
350 \\
850 \\
1,615 \\
.1,651 \\
\\
1,774 \\
1,808 \\
1,907\end{array}$ & \begin{tabular}{r} 
Feet. \\
$\cdots \ldots . .$. \\
\hdashline$\ldots .$. \\
\hdashline 40 \\
\\
23 \\
19 \\
42
\end{tabular} & $\begin{array}{l}\text { Water. } \\
\text { Black oil and water. } \\
\text { Gas at } 1,911 \text { feet. }\end{array}$ \\
\hline
\end{tabular}

FINLEY AND MOON TOWNSHIPS, ALLEGHENY COUNTY.

Only portions of Moon and Finley townships are embraced in the Carnegie quadrangle. Though these two townships include all of that part of the quadrangle lying northwest of Montour Creek, a large part of Finley lies farther west in the Burgettstown and Beaver. quadrangles, and Moon Township extends north to Ohio River in the Sewickley quadrangle; the portions of these townships lying outside the Carnegie quadrangle have been discussed in previous survey reports. ${ }^{a}$ That portion lying within this quadrangle includes part of the Imperial and the Moon oil and gas fields and the McCormick pool, together with several very small pools of oil and gas that are represented by scattered wells. In this region the Nineveh Thirtyfoot, the Gordon, the Hundred-foot, the so-called Bowlder, and the Fifth sands produce more or less oil and gas, by far the greatest amount coming from the Nineveh Thirty-foot and the Gordon.

Imperial oil and gas field.-The pool known as the Imperial oil and gas field extends from the south into Finley and Moon townships. The production is mostly from the Nineveh Thirty-foot sand, though some wells have made more or less oil from the Hundred-foot sand and gas from the Bowlder (?) sand. Water occurs in the Salt sand and also in many wells in the Big Injun and the Hundred-foot sands. The Fifth sand is absent over much of the southern parts of both these townships and is seldom reported in logs of wells in the Imperial field. The Fourth sand is usually represented here by thin sandstone "shells" and shale; and is not reported as containing oil, gas, or water. The other oil sands produce no water.

The oil in the Nineveh Thirty-foot sand occurs from 6 to 20 feet below the top in pay streaks varying from less than 1 foot to 10 or 15 feet in thickness. Few of the wells flowed when first drilled in, but most of them filled up several hundred feet with oil. None of the wells were very large; many of them, however, yielded from 25 to

a For portion in Burgettstown quadrangle see Bulletin 318; for Beaver quadrangle, see Folio 134 and Bulletin 279; for Sewickley quadrangle, see Folio 176. (See also oil and gas bulletin to be published by the Top. and Geol. Survey Comm. Pennsylvania.) 
100 barrels per day, and are considered by producers to be capable of furnishing oil for a long time.

The most northeastern extension of the Nineveh Thirty-foot pool in the Imperial field is in the wells in the vicinity of No. 98. In this part of the field the Hundred-foot sand produces salt water in one well and is apparently dry in the next. In well No 98 a small amount of salt water was found in the Gordon sand, which is here only 7 feet thick. The Fourth sand is 8 feet thick in this well, and the Fifth sand is absent.

McCormick oil and gas field.-The McCormick field appears to be entirely cut off by an unproductive strip of territory from the northern end of the Imperial field in the vicinity of well No. 98. Oil occurs in the Hundred-foot and the Nineveh Thirty-foot sands, but from the available facts the former seems to have been the most productive. The Gordon, the Fourth, and the Fifth sands are all present in normal thickness in this field and are gas bearing to a greater or less extent. Less than a dozen records of wells in the field are available. Of these Nos. 99 and 111 show the thickness of the oil-bearing sands, with the exception of the Fifth sand, which ranges up to about 20 feet in thickness. In one or two wells gas was also found in considerable quantities in what is called the Sixty-foot sand, which is probably equivalent to the Connoquenessing sandstone member of the Pottsville formation. This gas was accompanied by large quantities of salt water, which soon shut off the flow. The McCormick field is now practically exhausted and most of the wells have been abandoned.

Ewings Mill oil and gas field.-Northeast of the McCormick field a few wells in the vicinity of Ewings Mill have found gas in the Hundredfoot, the Nineveh Thirty-foot, and the Gordon sands, and have flowed more or less oil from the Hundred-foot and the Gordon sands, but the total amount of oil obtained was small. The wells have been good gas producers, however, and still furnish considerable quantities.

From the map (Pl. IV) it will be seen that the Imperial, the McCormick, and the Ewings Mill fields form a chain of pools in the different producing sands extending across the northwest corner of the quadrangle from northeast to southwest. Northwest of this productive belt occurs a barren area from 1 to 2 miles in width in which only small isolated pools occur. In this area the Fifth, the Fourth, and the Gordon sands furnish most of the gas, which is in such small pools that each is adequately drained by one or two wells.

Aten oil and gas field.-The largest productive area within this barren belt is the Aten field, which has furnished oil from the Hundredfoot sand in a dozen or more wells, and gas from the Gordon, the Fourth, and the Fifth sands. With the exception of the Hindredfoot, these sands change greatly in thickness and quality in short distances within the field. This is especially true of the Fifth sand, 
which is found in small lenses that apparently pinch out in all directions. The Gordon sand appears to be a continuous bed over the whole area, but seldom reaches its normal thickness. Attention is called to the fact that farther up the dip of the sand toward the north the Gordon sand is oil bearing, and contains salt water in both the Moon and the Coraopolis pools, whereas below them in the Aten and the McCormick fields and in the barren area surrounding them this sand shows no salt water and sometimes contains considerable quantities of gas.

This field is 10 or 15 years old, and now furnishes only a few barrels of oil per day from a small number of wells. The supply of gas is also greatly reduced.

Well No. 94 on the G. W. Beitsinger farm was drilled in 1907 in an endeavor to find a southwestern extension of the Aten field. This well produced a small amount of gas from the Hundred-foot sand, which is here 28 feet thick and without water. The well was drilled through the horizon of the Gordon and possibly to that of the Fourth sand, but no sand was found below the Hundred-foot. It seems probable that the horizon of the Fifth sand was not reached in this well. In well No. 97 on the John Irving farm, the Hundred-foot, the Gordon, and the Fourth sands were found to be 40, 20, and 13 feet thick, respectively. No statement is made in the record of this well concerning the water conditions in these sands. However, the first well to the south of No. 97, on the Stoddard farm, is said to have been drilled to a depth of 2,187 feet without finding sufficient water to justify the use of casing. This is one of the rare instances where a well within the oil region of southwestern Pennsylvania has been sunk more than 2,000 feet without finding considerable quantities of salt water in some of the sandstones through which it passed. This fact appears more remarkable when it is remembered that one or more of the beds of the Pottsville formation and the Burgoon sandstone member of the Pocono formation, which are equivalent to the Salt, the Gas, and the Big Injun sands, are highly charged with salt water at almost every place where they have been touched by the drill in this quadrangle. In the Coraopolis oil field less than $1 \frac{1}{2}$ miles north of well No. 97 and directly up the slope of the rocks, the Gordon sand contains salt water in such quantities and under such head that it is slowly drowning out the wells which obtain their oil from that sand.

Moon oil pool.-The northwest corner of the Carnegie quadrangle includes a portion of the southern end of the Moon pool in the Gordon sand. This pool lies both north and west of the limits of the quadrangle and probably covers as much as a square mile. This pool has furnished a considerable quantity of oil, many of the wells having 
had a maximum capacity of 25 to 100 barrels per day. Most of the wells have been producing for from 12 to 18 years, and are almost pumped out; others have been invaded by salt water from the Gordon sand in such quantities as to shut off the supply of oil.

In a few wells the Hundred-foot sand has furnished limited quantities of both oil and gas, which was in most cases accompanied by salt water. The Fourth sand is gas bearing in a few wells in the vicinity of the Moon pool, and it seems probable that the Fifth sand also contains more or less gas in areas where it is present in good quality, but no specific instances are mentioned in the logs of wells.

Partial records of deep wells in that portion of Finley and Moon townships, Allegheny County, Pa.; included within the Carnegie quadrangle.

\begin{tabular}{|c|c|c|c|c|c|c|c|}
\hline $\begin{array}{l}\text { Map } \\
\text { No. }\end{array}$ & Name. & Owner. & $\begin{array}{l}\text { Alti- } \\
\text { tude. }\end{array}$ & Name of stratum. & $\begin{array}{l}\text { Depth } \\
\text { to top. }\end{array}$ & $\begin{array}{l}\text { Thick- } \\
\text { ness. }\end{array}$ & Remarks. \\
\hline 94 & $\begin{array}{l}\text { G. W. Beitsin- } \\
\text { ger No. } 1 .\end{array}$ & $\begin{array}{l}\text { MeClay Drilling } \\
\text { Co. }\end{array}$ & $\begin{array}{l}\text { Feel. } \\
1,072\end{array}$ & $\begin{array}{l}\text { Salt sand......... } \\
\text { Big Injun sand .. } \\
\text { Bitter rock sand. } \\
\text { Broken sand.... } \\
\text { Hundred - f o o t } \\
\text { Sand. }\end{array}$ & $\begin{array}{l}\text { Fcet. } \\
850 \\
1,105 \\
1,345 \\
1,600 \\
1,777\end{array}$ & $\begin{array}{r}\text { Feel. } \\
110 \\
\\
200 \\
15 \\
95 \\
28\end{array}$ & $\begin{array}{l}\text { Depth of well, } 2,054 \\
\text { feet; water. } \\
\text { No water in or below } \\
\text { Flundred-footsand. } \\
\text { Small gas well at } \\
1,780 \text { feet. }\end{array}$ \\
\hline 95 & $\begin{array}{l}\text { Stewart heirs } \\
\text { No. } 1 .\end{array}$ & $\begin{array}{l}\text { Ohio Valley Gas } \\
\text { Co. }\end{array}$ & 1,070 & $\begin{array}{l}\text { Fourth sand..... } \\
\text { Fifth sand....... }\end{array}$ & $\begin{array}{l}1,750 \\
2,080 \\
2,117\end{array}$ & $\begin{array}{l}\ldots \\
134\end{array}$ & $\begin{array}{l}\text { Depth of well, } 2,131 \\
\text { feet. }\end{array}$ \\
\hline 96 & $\begin{array}{l}\text { H. A. } \Lambda \text { ten } \\
\text { No. } 3 \text {. }\end{array}$ & Forest Oil Co..... & 1,077 & $\begin{array}{l}\text { Hundred -f o o t } \\
\text { sand. } \\
\text { Gordon sand.... } \\
\text { Fourth sand..... } \\
\text { Fifth sand....... }\end{array}$ & $\begin{array}{l}1,819 \\
2,056 \\
2,128 \\
\ldots \ldots \ldots\end{array}$ & 38 & $\begin{array}{l}\text { Depth of well, } 2,179 \\
\text { feet; gas at } 1,820 \\
\text { feet. } \\
\text { Gas at } 2,128 \text { feet. } \\
\text { None; shells and }\end{array}$ \\
\hline 97 & J. Ewing No.1. & Montour Gas Co.. & 968 & $\begin{array}{l}\text { Hundred - f o o t } \\
\text { sand. } \\
\text { Gordon sand.... } \\
\text { Fourth sand... }\end{array}$ & $\begin{array}{l}1,690 \\
1,920 \\
1,990\end{array}$ & $\begin{array}{l}40 \\
20 \\
13\end{array}$ & \\
\hline 98 & J. B. Meanor... & Leonard \& Co... & 922 & $\begin{array}{l}\text { Fundred - f o o t } \\
\text { sand. } \\
\text { Thirty-foot sand } \\
\text { Bowlder sand ... } \\
\text { Gordon sand.... } \\
\text { Fourth sand.... }\end{array}$ & $\begin{array}{l}1,660 \\
1,786 \\
1,832 \\
1,939 \\
1,988\end{array}$ & $\begin{array}{r}35 \\
25 \\
15 \\
7 \\
8\end{array}$ & $\begin{array}{l}\text { No water; depth of } \\
\text { well, } 2,157 \text { feet; oil } \\
\text { at } 1,793 \text { feet; gas at } \\
1,807 \text { feet. } \\
\text { Little water. } \\
\text { No Fifth sand. }\end{array}$ \\
\hline 99 & J. McCormick. & $\begin{array}{l}\text { South Penn Oil } \\
\text { Co. }\end{array}$ & 1,111 & $\begin{array}{l}\text { Hundred - f o ot } \\
\text { sand. } \\
\text { 'Lhirty-foot sand } \\
\text { Cordon s and } \\
\text { (estimated). } \\
\text { Fourth sand..... }\end{array}$ & $\begin{array}{l}1,840 \\
1,974 \\
2,056 \\
2,098\end{array}$ & $\begin{array}{l}45 \\
43\end{array}$ & $\begin{array}{l}\text { Gas at } 1,845 \text { feet; oil } \\
\text { at } 1,855 \text { feet; oil at } \\
2,012 \text { feet. } \\
\text { Gas at } 2,101 \text { feet. }\end{array}$ \\
\hline 100 & Scott No. 1... & $\begin{array}{l}\text { Philadelphia Gas } \\
\text { Co. }\end{array}$ & ...... & $\begin{array}{l}\text { Sand, white...... } \\
\ldots \ldots \text { do ........... }\end{array}$ & $\begin{array}{l}1,618 \\
1,845\end{array}$ & $\begin{array}{r}30 \\
9\end{array}$ & $\begin{array}{l}\text { Salt water. } \\
\text { Oil; depth of well, }\end{array}$ \\
\hline 101 & C. Ehle No. 3. & $\begin{array}{l}\text { Manu facturers } \\
\text { Light \& Heat } \\
\text { Co. }\end{array}$ & 1,093 & 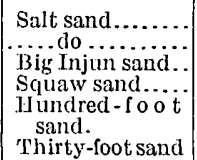 & $\begin{array}{r}800 \\
870 \\
990 \\
1,330 \\
1,850 \\
1,974\end{array}$ & $\begin{array}{r}40 \\
100 \\
150 \\
50 \\
30 \\
12\end{array}$ & $\begin{array}{l}\text { Total depth, 2,290 } \\
\text { feet. }\end{array}$ \\
\hline 102 & $\begin{array}{l}\text { Mary Johnston } \\
\text { No. 13. }\end{array}$ & .....do... & 1,078 & $\begin{array}{l}\text { Salt sand......... } \\
\text { Big Injun sand...... } \\
\text { Squaw sand ..... } \\
\text { Hundred - f o o t } \\
\text { sand. } \\
\text { Thirty-foot sand }\end{array}$ & $\begin{array}{r}820 \\
870 \\
1,050 \\
1,350 \\
1,828 \\
1,960\end{array}$ & $\begin{array}{r}40 \\
105 \\
250 \\
40 \\
44 \\
21\end{array}$ & $\begin{array}{l}\text { Depth of well, } 1,983 \\
\text { feet. } \\
\text { Break, } 5 \text { feet; slateat } \\
1,847 \text { feet. } \\
\text { First show of oil. }\end{array}$ \\
\hline
\end{tabular}


Partial records of deep wells in that portion of Finley and Moon townships, Allegheny County, Pa., included within the Carnegie quadrangle-Continued.

\begin{tabular}{|c|c|c|c|c|c|c|c|}
\hline $\begin{array}{l}\text { Map } \\
\text { No. }\end{array}$ & Name. & Owner. & $\begin{array}{l}\text { Alti- } \\
\text { tude. }\end{array}$ & Name of stratum. & $\begin{array}{l}\text { Depth } \\
\text { to top. }\end{array}$ & $\begin{array}{l}\text { Thick- } \\
\text { ness. }\end{array}$ & Remarks. \\
\hline 103 & $\begin{array}{l}\mathrm{R} \text {. Jeffery } \\
\text { No. } 2 \text {. }\end{array}$ & & $\begin{array}{l}\text { Feet. } \\
1,045\end{array}$ & 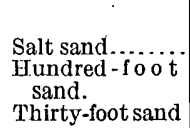 & $\begin{array}{r}\text { Feet. } \\
845 \\
1,840 \\
\\
1,978\end{array}$ & $\begin{array}{r}\text { Feet. } \\
157 \\
44 \\
14\end{array}$ & . \\
\hline 104 & Stewart No. 1.. & 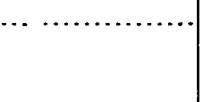 & 873 & $\begin{array}{l}\text { Hundred - f o ot } \\
\text { sand. } \\
\text { Thirty-foot sand } \\
\text { Bowlder sand... }\end{array}$ & $\begin{array}{l}1,633 \\
1,752 \\
1,798\end{array}$ & $\begin{array}{l}45 \\
18\end{array}$ & $\begin{array}{l}\text { Depth of well, } 1,811 \\
\text { feet. } \\
\text { Pay at } 6 \text { to } 9 \text { feet. } \\
\text { Gas at } 1,806 \text { feet. }\end{array}$ \\
\hline 105 & $\begin{array}{l}\text { Wm. Adams } \\
\text { No. } 6 .\end{array}$ & . & 987 & $\begin{array}{l}\text { Hundred - f o o t } \\
\text { sand. } \\
\text { Thirty-foot sand } \\
\text { Bowlder sand... } \\
\text { Gordon sand.... } \\
\text { Fourth sand .... }\end{array}$ & $\begin{array}{l}1,740 \\
1,863 \\
1,912 \\
1,998 \\
2,070\end{array}$ & $\begin{array}{r}18 \\
5 \\
35 \\
8\end{array}$ & $\begin{array}{l}\text { Depth of well, } 2,145 \\
\text { feet. } \\
\text { Pay at } 1,869-1,874 \\
\text { feet. } \\
\text { Show of gas. } \\
\text { Good pebbly sand. } \\
\text { No Fifth sand. }\end{array}$ \\
\hline 106 & $\begin{array}{l}\text { Wm. Adams } \\
\text { No. } 1 .\end{array}$ & & 995 & $\begin{array}{l}\text { Hundred - f o o t } \\
\text { sand. } \\
\text { Thirty-foot sand }\end{array}$ & $\begin{array}{l}1,738 \\
1,870\end{array}$ & 45 & $\begin{array}{l}\text { Depth of well, } 1,936 \\
\text { feet. } \\
\text { Oil at } 1,895 \text { feet. }\end{array}$ \\
\hline 107 & $\begin{array}{l}\text { A. } \mathrm{A} \mathrm{dams} \\
\text { No. } 2 .\end{array}$ & & 989 & $\begin{array}{l}\text { Hundred-f foot } \\
\text { sand. }\end{array}$ & 1,736 & 45 & Oil, $1,880-1,890$ feet. \\
\hline 108 & Knopf No. 3... & $\begin{array}{l}\text { Philadelphia Gas } \\
\text { Co. }\end{array}$ & 838 & $\begin{array}{l}\text { Thirty-foot sand } \\
\text { Gordon sand.... }\end{array}$ & $\begin{array}{l}1,537 \\
1,714 \\
1,812\end{array}$ & $\begin{array}{l}75 \\
22\end{array}$ & $\begin{array}{l}\text { Freeportcoal, } 400 \text { feet. } \\
\text { Gas at } 1,717 \text { feet. }\end{array}$ \\
\hline 109 & $\begin{array}{l}\text { Dorring ton } \\
\text { No. } 1 .\end{array}$ & $\begin{array}{l}\text { Manuf a cturers } \\
\text { Light \& Heat } \\
\text { Co. }\end{array}$ & 778 & $\begin{array}{l}\text { Salt sand........ } \\
\text { Big Injun sand.. } \\
\text { Hundred - f o o t } \\
\text { sand. } \\
\text { Thirty-foot sand } \\
\text { Gordon sand.... } \\
\text { Bottom sand.... }\end{array}$ & $\begin{array}{r}500 \\
690 \\
1 \quad 465 \\
1,641 \\
1,641 \\
1,745 \\
1,765\end{array}$ & $\begin{array}{r}130 \\
220 \\
40\end{array}$ & $\begin{array}{l}\text { Salt water at } 190 \text { feet. } \\
\text { Freeport coal at } 325 \\
\text { feet. } \\
\text { Break, sand, and } \\
\text { slate; oil at } 1,495 \\
\text { feet. } \\
\text { Gas at } 1,750 \text { leet. }\end{array}$ \\
\hline 110 & T. M. Ewing... & $\begin{array}{l}\text { Philadelphia Gas } \\
\text { Co. }\end{array}$ & 754 & $\begin{array}{l}\text { Hundred -f o o t } \\
\text { sand. } \\
\text { Thirty-foot sand } \\
\text { Gordon sand .... } \\
\text { Fourth sand... }\end{array}$ & $\begin{array}{l}1,420 \\
1,595 \\
1,690 \\
1,770\end{array}$ & $\begin{array}{l}78 \\
15 \\
15 \\
10\end{array}$ & $\begin{array}{l}\text { Depth of well, } 2,005 \\
\text { feet. } \\
\text { Gas at } 1,700 \text { feet. } \\
\text { Gas at } 1,772 \text { feet. }\end{array}$ \\
\hline 111 & Anna Wilson.. & ....do.. & 1,079 & $\begin{array}{l}\text { Fifty-foot sand.. } \\
\text { Stray sand...... } \\
\text { Gordon sand.... } \\
\text { Fourth sand.... }\end{array}$ & $\begin{array}{l}1,840 \\
2,020 \\
2,076 \\
2,185\end{array}$ & $\begin{array}{r}27 \\
76 \\
27 \\
7\end{array}$ & $\begin{array}{l}\text { Depth of well, } 2,210 \\
\text { feet. } \\
\text { Gas at } 2,089 \text { feet. }\end{array}$ \\
\hline
\end{tabular}

From this table it will be seen that the oil sands as a whole are variable throughout the area. This is emphasized by a study of all the records and other data that are available regarding these sands. From these facts it seems very probable, however, that the Hundredfoot sand is present throughout the two townships, and that the Nineveh Thirty-foot and the Gordon sands, though subject to more variations in thickness and texture than the Hundred-foot, may still be considered as fairly constant in occurrence. The Fourth and the Fifth sands show great changes in thickness and texture in short distances, and the Fifth sand especially is evidently made up of a number of small disconnected lenses which occupy about the same horizon.

\section{ROBINSON AND STOWE TOWNSHIPS, ALLEGHENY COUNTY.}

Robinson and Stowe townships lie east and northeast of Moon, Findley, and North Fayette townships, and include most of the productive areas northeast of the McDonald field. It is not possible 
to say definitely that these pools are extensions of the McDonald field and are therefore directly connected with it, yet there is no doubt that they are closely related structurally, and that they are not only contemporaneous but have all been formed by the same geologic processes, whatever these may have been. In a study of these pools it is therefore well to keep in mind the general conditions described in the McDonald field, and to consider them as virtually belonging to the same general area of accumulation, though they may not in fact be parts of the same pools.

From the junction of North Fayette, Collier, and Robinson townships northeast to the vicinity of Union Church the Fifth sand is the principal oil-bearing bed. From Moon Run north to Ohio River at the head of Neville Island the Gordon and the Gordon Stray sands also furnish oil or gas in an almost continuous belt. The Gordon sand also appears to be productive from Moon Run east to Chartiers Creek south of McKees Rocks. From Ewings Mills east across the northern edge of the quadrangle to Neville Island the Hundred-foot sand is the principal oil producer. In this area the Gordon, the Fourth, and the Fifth sands furnish more or less gas. In the vicinity and south of Beacon a considerable pool of oil in the Nineveh Thirty-foot sand has been developed. Here the Hundredfoot sand is also oil-bearing, and frequently small pools of gas are found in the Fifth sand.

McDonald oil field.-A small area in the southwest corner of Robinson Township south of Campbells Creek seems to be the northeast limit of the Fifth sand pool of the McDonald field, though it is possible that the Fifth has a continuous oil-bearing belt from this field in the vicinity of well No. 68 eastward into the McCurdy pool and thence to the pools in the Moon Run field farther north. From the available data, however, it seems that a narrow belt of unproductive territory near the head of Campbells Creek may possibly cut off the McDonald field from the McCurdy field, and that another dry belt may lie between the latter and the Moon Run field.

The Fifth sand in the southwest corner of Robinson Township has a maximum thickness of as much as 35 or 40 feet. Toward the north and west the sand seems to be very irregular and on the whole is much thinner. It is not known by the writer from what sand the wells at the head of Pinkertons Creek produce, but in the Hall Kelso well No. 8 (No: 151 on map) only 4 feet of sand is recorded in a very imperfect log. Other data obtained from drillers indicate that the Fifth -sand here shows its characteristic variations in thickness.

The capacity of the wells of this part of the McDonald field is not known, but it is believed that formerly some of them produced several hundred barrels per day. They have 'long since been pumped down to a production which is becoming smaller each year, and 
after a few years will doubtless cease. The oil is encountered only in the softer, more porous portions of the sand, many of these pay streaks being largely made up of small water-worn quartz pebbles.

The other sands of this area are strikingly barren of either oil or gas. In a few places the Hundred-foot sand shows more or less gas at the top, with salt water in the lower part. But little can be learned from the available records of the thickness and texture of these sands. In well No. 148 the Hundred-foot and the Gordon sands are shown to be 66 and 25 feet thick, respectively. No mention is made of the Fourth sand, and it may be absent or represented only by "slate and_shells."

The Fifth sand is said to produce small amounts of salt water in most of these wells. Salt water is also encountered in the Hundredfoot sand, which in a few wells arose several hundred feet. The Gordon sand shows no water in this field.

McCurdy oil field.-The McCurdy pool was developed in 1890-1893. A well brought in on October 16,1890, on the McCurdy farm began flowing at the rate of 600 barrels per day. The development of the field followed rapidly. . In May, 1891, wells on the W. E. Riddle and Jane Riddle farms began flowing at from 60 to 100 barrels per hour. About the same time a well on the parsonage lot of the Union Church property came in at 60 barrels per hour. Probably the best well in the field was on the Bell farm, which began flowing at the rate of 200 barrels per hour. Many of the wells which followed produced from 50 to 100 barrels per day.

The oil came from the Fifth sand, which is here from 10 to 30 feet in thickness, with an average of scarcely 20 feet. Regardless of the thin sand, however, these wells have produced an enormous quantity of oil, and many of them, after 18 years of constant pumping, still furnish from 1 to 10 barrels per day. The Fifth sand is said to show some water in this pool, as does also the Hundred-foot, but data relative to the water conditions are too meager to be of value.

The Gordon and the Hundred-foot sands furnished some gas in this field, but the Fourth sand appears to be of no importance. From the available data it is difficult to outline the McCurdy field on the northeast, since it is not possible to point out the limit of the Fifth sand oil pool in that direction.

Moon Run oil field.-In this paper the name Moon Run is tentatively applied to the field in the vicinity of the village of Moon Run, thence north to Ohio River and east as far as Chartiers Creek.

In the immediate vicinity of Moon Run and eastward the Gordon sand furnishes most of the oil; north the Fifth becomes the principal oil producer and the Gordon carries gas. Very few wells in this field furnish oil in the Fourth sand. Many of the wells show some water in the Gordon sand, but only in small quantities. The 
Fourth and the Fifth sands usually show no salt water, though small quantities are sometimes found.

The thickness of the Gordon sand in the Moon Run field appears from the records to vary between 10 and 66 feet, with an average of between 30 and 50 feet. The apparent increased thickness of this sand from what it is farther southwest seems to be due to the union of the Gordon Stray and the Gordon into a single bed of sandstone. No conclusive evidence is available to settle this point, but the combination of the sands, as indicated by the interval from the Pittsburg coal to the Gordon Stray (where that sand is differentiated by drillers), is about the same as that from the Pittsburg coal to the top of the Gordon sand in those areas where it has its maximum thickness. In areas where both the Gordon and the Gordon Stray sands are reported, the former is rarely more than 25 or 30 feet in thickness; furthermore, where the Gordon is thickest the Gordon Stray is not mentioned in the records; but in some of them a hard streak of sand near the middle of the Gordon is reported as separating two distinct pay streaks. This evidence taken collectively over both these townships seems to justify the conclusion that the Gordon and the Gordon Stray sands frequently unite into a single stratum, with a total thickness of 40 to 65 feet. With this possibility in mind, it becomes evident that contours drawn on the top of what the drillers term the Gordon sand may possibly involve considerable error, since in one well the elevation of the top of the Gordon sand may be used and in some other well where the two sands are united the top of the so-called Gordon may be in reality at the horizon of the Gordon Stray sand. It is, therefore, well to remember in studying the structure map that in those areas where the Gordon sand is shown by the records in the table within to be thickest; the top of the true Gordon sand may be from 20 to 30 feet below that shown by the contours.

Oil in the Gordon sand in the vicinity of Moon Run and east of that point is generally found in a pay streak from 3 to 15 feet below the top of the sand. This pay streak is seldom more than 10 feet in thickness and will probably average less than 5 feet. It is soft and usually composed of coarse sand with a variable quantity of quartz pebbles scattered through it. In a number of records, of which that of well No. 142 in the table given within is an example, no show of either oil or gas was encountered in drilling the well until several feet of the sand had been penetrated; then within the space of 5 feet, and sometimes even less, the whole volume of gas and oil would be tapped and turned loose with a pressure sufficient to fill up the hole for hundreds of feet and even to flow at the rate of several hundred barrels per day. Below such an oil zone many wells passed through several feet of somewhat harder, closer sandstone, which showed no indication of 
carrying oil, gas, or water. When it is remembered that this barren portion of the sand has a minimum porosity of probably not less than 5 per cent of its volume, and in most cases probably as much as 10 per cent, the explanation of the occurrence of oil and gas exclusively in certain thin porous portions of the sand becomes very difficult.

In a few wells in the vicinity of No. 141 oil was obtained in the Gordon, the Fourth, and the Fifth sands, but the pools in the last two seem to be very small. In well No. 140 the Gordon and the Fourth sands were found to be gas bearing at depths of 3 and 5 feet, respectively, in the sands, and an oil pay streak was found near the bottom of the Fifth sand 49 feet from the top.

In the northern portion of the Moon Run field, near wells Nos. 132135 , the Fifth sand, which is the principal oil-bearing bed, is from 40 to more than 50 feet thick. In a few wells this sand carries two pay streaks, one near the top and another near the bottom, but the lower pay is far more extensive as well as more productive than the upper. In this pay streak the oil occurs from 30 to 50 feet below the top of the sand.

In the Martin Clever No. 6 well (No. 132) and in another well on the Charles Arbuckle property about 500 feet farther north, the Fifth sand is the producing sand. These two wells are surrounded on all sides by dry holes in the Fifth, but two locations southwest of this pool the Fifth again is oil bearing. From this point northeast to Ohio River the Gordon and the Fifth sands rarely carry oil, but in many wells they have produced large quantities of gas. In that direction the Fourth sand is oil bearing and has supplied some of the best wells found in this field. Well No. 131, which is known as Speer No. 1, produces oil from the Fourth sand, which here has a thickness of 52 feet. The first oil was found in it $31 \frac{1}{2}$ feet below the top of the sand, the pay streak extending to the bottom of the sand, a distance of $20 \frac{1}{2}$ feet. The well began flowing at the rate of 250 barrels a day when the pay streak had been penetrated to a depth of 15 feet. This is another instance of a portion of a sandstone being saturated by oil and gas under great pressure, whereas associated portions appear to show little or no oil or gas. The theory which fully satisfies the facts as they are found by the drill must provide an explanation of this phenomenon.

North of well No. 131 the oil in the Fourth sand is replaced by gas in well No. 9 on the Ewing farm (No. 121). Thence north to Ohio River the Fourth sand is gas bearing in nearly all the wells drilled to that horizon.. Northeast of well No. 131 the Fourth sand oil pool pinches out entirely south of well No. 130. This well found oil and gas in the Fifth sand and flowed at the rate of 40 barrels per hour. In this well the upper 6 feet of the Fifth sand are gray; the next 6 feet are white. Oil was found 12 feet from the top of the sand, in a softer, 
apparently more porous part of the sand which extended to the bottom of the bed, a distance of 28 feet. These conditions in the Fifth sand are similar to those pointed out in the Fourth sand in well No.131. Gas was also encountered in the Gordon Stray sand 24 feet below the top in well No. 130. In well No. 129 a show of oil was encountered in the Fifth sand, 14 feet below the top, and another better one 40 feet below the top and 7 feet from the bottom of the sand. No gas was recorded in this well.

Wells Nos. 127 and 128 obtained gas in the Fourth sand 9 and 10 feet, respectively, below the top, and in No. 128 a second pay streak of gas was encountered 20 feet below the top of the sand. No. 127 . found a showing of oil in the Fifth sand, 30 feet below the top and 5 feet from the bottom.

On Neville Island well No. 126, on the Bragdon property, found salt water in "shaly slate" 87 feet above the top of the Hundred-foot sand, in which sand oil and gas were found 61 feet below the top. A show of oil was also found in the Fifth sand in this well.

In well No. 125, on the Hamilton farm, two pay streaks of gas were encountered in the Gordon sand 5 and 10 feet, respectively, below the top. Well No. 124 on the A. P. Cole property found oil in the Hundred-foot sand 27 feet below the top, with gas in the Gordon sand 10 feet below the top. In well No. 121 south of Neville Island oil was found in the Hundred-foot sand at 10 and 45 feet below the top of the sand. Gas also occurs in the Fourth sand in this well 42 feet below the top of the sand. In well No. 122 oil in the Hundred-foot occurs 40 feet below the top, with gas in the Fourth 38 feet below the top of the sand. Practically the same conditions as described above obtain in the majority of the wells of this field. In No. 121 the first oil was found 30 feet in the Hundred-foot sand with an 8-foot pay streak. Gas occurs in both the Fourth and the Fifth sands in this well (No. 121) at depths of 4,3 , and 8 feet, respectively. 'In well No. 116 oil was found in the Hundred-foot sand at 38 feet, oil and salt water at 43 feet, and oil at 47 feet below the top of the sand; in this well the Gordon, the Fourth, and the Fifth sands are unproductive. In well No. 118 the pay streak is 10 feet thick and extends from 47 to 57 feet below the top of the Hundred-foot sand and from 10 to 20 feet below a 15-foot shale "break" in the sand. Above this pebbly pay streak the driller reports 10 feet of fine white sand. The Third or Gordon sand in this well carries gas 5 feet from the top in a fine white sand. The Fourth and the Fifth sands are fine grained and show no oil, gas, or salt water. In well No. 119 two pay streaks in the Hundred-foot sand, 33 and 60 feet below the top, were both found to be "white and hard." In well No. 115 oil was found 28 and 45 feet below the top of the Hundred-foot sand in pay. streaks 7 and 10 feet thick; the lower of these pay streaks carries salt water with the oil. In this well both

$83448^{\circ}-$ Bull. $456-11-5$ 
the Fourth and the Filth sands are gas bearing, the Fourth with two pay streaks 13 and 23 feet below the top, and the Fifth with one pay streak 16 feet below the top of the sand. The conditions shown to prevail in the oil sands in these wells are found to extend over most of the Moon Run field southwest of well No. 117. The oil in the vicinity of wells Nos. 120, 114, and 113 comes mainly from the Hundred-foot sand, though the Fourth sand is productive in one or more wells on the Magnuss Heirs farm. Well No. 112 is in the Ewings Mill field and obtains gas from the Nineveh Thirty-foot and the Gordon sands. This Hundred-foot oil pool extends for some distance south of Beacon and possibly overlaps the Fifth sand pool in the McCurdy field.

In some of the wells of this area the Nineveh Thirty-foot sand furnishes oil, and the Fourth and Fifth sands are gas bearing. Spirit level lines were run to most of the wells of this area and the elevation above sea level of the top of the casing in each of them was determined, but diligent search failed to furnish a single record of the wells, and hence nothing of value regarding the condition of the sands is available.

The following table of records gives some idea of the stratigraphic conditions of the oil sands in these two townships:

Partial records of deep wells in Robinson and Stowe townships, Allegheny County, Pa.

\begin{tabular}{|c|c|c|c|c|c|c|c|}
\hline $\begin{array}{l}\text { Map } \\
\text { No. }\end{array}$ & Name. & Owner. & $\begin{array}{l}\text { Alti- } \\
\text { tude. }\end{array}$ & Name of stratum. & $\begin{array}{l}\text { Depth } \\
\text { to top. }\end{array}$ & $\begin{array}{c}\text { Thick- } \\
\text { ness. }\end{array}$ & Remarks. \\
\hline 112 & E. M. Ewing... & Philadelphia Co.. & $\begin{array}{r}\text { Feet. } \\
767\end{array}$ & $\begin{array}{l}\text { Hundred - f o o t } \\
\text { sand. } \\
\text { Thirty-foot sand } \\
\text { Stray sand...... } \\
\text { Gordon sand.... } \\
\text { Fourth sand.... }\end{array}$ & $\begin{array}{l}\text { Feet. } \\
1,423 \\
1,595 \\
1,697 \\
1,725 \\
1,778\end{array}$ & $\begin{array}{r}\text { Feet. } \\
77 \\
10 \\
6 \\
15 \\
17\end{array}$ & $\begin{array}{l}\text { Depth of well, } 1,975 \\
\text { feet. } \\
\text { Gas at } 1,600 \text { feet. } \\
\text { Gas at } 1,735 \text { feet. }\end{array}$ \\
\hline 113 & $\begin{array}{l}\text { J. McElhern } \\
\text { No. } 1 .\end{array}$ & A. G. Davis..... & 1,086 & $\begin{array}{l}\text { Hundred - } f_{0} \text { ot } \\
\text { sand. } \\
\text { Fourth sand.... } \\
\text { Fifth sand...... }\end{array}$ & $\begin{array}{l}1,753 \\
2,074 \\
2,120\end{array}$ & $\begin{array}{r}80 \\
.16\end{array}$ & $\begin{array}{l}\text { Oil at } 1,759 \text { and } 1,767 \\
\text { feet. } \\
\text { Depth of well, } 2,129 \\
\text { feet. }\end{array}$ \\
\hline 114 & $\begin{array}{l}\text { Magnus heirs } \\
\text { No. 1. }\end{array}$ & ....do............ & 1,080 & $\begin{array}{l}\text { Hundred - f o o t } \\
\text { sand. } \\
\text { Gordon sand.... } \\
\text { Fourth sand.... }\end{array}$ & $\begin{array}{l}1,736 \\
1,996 \\
2,049\end{array}$ & & $\begin{array}{l}\text { Depth of well, } 2,060 \\
\text { feet. } \\
\text { Coal and water at } 640 \\
\text { feet. } \\
\text { Pay at } 2,055 \text { feet. }\end{array}$ \\
\hline 115 & Gibson No. 3.. & S. D. Robison... & 1,145 & $\begin{array}{l}\text { Hundred - f o o t } \\
\text { sand. } \\
\text { Thirty-foot sand } \\
\text { Gordon sand.... } \\
\text { Fourth sand.... } \\
\text { Fifth sand...... }\end{array}$ & $\begin{array}{l}1,775 \\
1,943 \\
2,034 \\
2,100 \\
2,165\end{array}$ & $\begin{array}{l}45 \\
38 \\
33\end{array}$ & $\begin{array}{l}\text { Depth of well, } 2,200 \\
\text { feet; oil at } 1,803 \text { and } \\
1,820 \text { feet. } \\
\text { Gas at } 2,113 \text { and } 2,123 \\
\text { feet. } \\
\text { Gas at } 2,181 \text { feet. }\end{array}$ \\
\hline 116 & $\begin{array}{l}\text { A. B. Speer } \\
\text { No. } 2 \text {. }\end{array}$ & ....do... & 1,142 & $\begin{array}{l}\text { Hundred - f o o t } \\
\text { sand. } \\
\text { Thirty-foot sand } \\
\text { Gordon sand.... } \\
\text { Fourth sand.... } \\
\text { Fifth sand...... }\end{array}$ & $\begin{array}{l}1,803 \\
1,978 \\
2,071 \\
2,137 \\
2,200\end{array}$ & $\begin{array}{l}42 \\
30 \\
25\end{array}$ & $\begin{array}{l}\text { Oil at } 1,841,1,846 \text {, } \\
\text { and } 1,850 \text { feet; wa- wa } \\
\text { ter at } 1,846 \text { feet; } \\
\text { depth of well, } 2,257 \\
\text { feet. } \\
\text { Dry. } \\
\text { Do. }\end{array}$ \\
\hline 117 & Gibson No. 1... & .....do........ & 1,087 & $\begin{array}{l}\text { Hundred - } f_{0} \text { ot } \\
\text { sand. }\end{array}$ & 1,719 & & $\begin{array}{l}\text { Depth of well, } 1,788 \\
\text { feet; oil and water } \\
\text { at } 1,765 \text { feet; bot- } \\
\text { tom of pay, } 1,777 \\
\text { feet. }\end{array}$ \\
\hline
\end{tabular}


Partial records of deep wells in Robinson and Stowe townships, Allegheny County, Pa.Continued.

\begin{tabular}{|c|c|c|c|c|c|c|c|}
\hline $\begin{array}{l}\text { Map } \\
\text { No. }\end{array}$ & Name. & Owner. . & $\begin{array}{l}\text { Alti- } \\
\text { tude. }\end{array}$ & Name of stratum. & $\begin{array}{l}\text { Depth } \\
\text { of top. }\end{array}$ & $\begin{array}{l}\text { Thick- } \\
\text { ness. }\end{array}$ & Remarks. \\
\hline 118 & Gibson No. 1.. & $\begin{array}{l}\text { Laugh ner \& } \\
\text { Wally. }\end{array}$ & $\begin{array}{r}\text { Feet. } \\
878\end{array}$ & $\begin{array}{l}\text { Hundre d-font } \\
\text { sand. } \\
\text { Thirty-foot sand } \\
\text { Third sand...... } \\
\text { Fourth sand.... } \\
\text { Fifth Stray...... } \\
\text { Fifth sand...... }\end{array}$ & $\begin{array}{l}\text { Feet. } \\
1,528 \\
1,700 \\
1,783 \\
1,841 \\
1,875 \\
1,925\end{array}$ & $\begin{array}{r}\text { Feet. } \\
112 \\
\\
34 \\
30 \\
24 \\
12 \\
30\end{array}$ & $\begin{array}{l}\text { Depth of well, } 1,975 \\
\text { feet; oil at } 1,575- \\
1,585 \text { feet. } \\
\text { Gas at } 1,788 \text { feet. }\end{array}$ \\
\hline 119 & Matchett No. 2. & S. D. Robison.... & 1,049 & $\begin{array}{l}\text { Hundred - f o o t } \\
\text { sand. }\end{array}$ & 1,671 & $\ldots \ldots$ & $\begin{array}{l}\text { Depth of well, } 1,750 \\
\text { feet; first pay at } \\
1,704 \text { feet; bottom } \\
\text { second pay at } 1,735 \\
\text { feet. }\end{array}$ \\
\hline 120 & N. Nolte....... & $\begin{array}{l}\text { South Penn Oil } \\
\text { Co. }\end{array}$ & $\cdots \cdots \cdot$ & .....do .... & 1,530 & $\ldots \ldots$ & $\begin{array}{l}\text { Depth of well, } 1,582 \\
\text { feet; pay at } 1,533-\end{array}$ \\
\hline 121 & Ewing No. 9... & S. D. Robison.... & 1,035 & $\begin{array}{l}\text { Big Injun sand.. } \\
\text { Hundred - f o ot } \\
\text { sand. } \\
\text { Thirty-foot sand } \\
\text { Fourth sand.... } \\
\text { Fifth sand...... }\end{array}$ & $\begin{array}{l}1,000 \\
1,700 \\
1,852 \\
2,020 \\
2,108\end{array}$ & $\begin{array}{r}\ldots \ldots \\
112\end{array}$ & $\begin{array}{l}\text { Depth of well, } 2,155 \\
\text { feet. } \\
\text { Oilat } 1,730-1,738 \text { feet; } \\
\text { bottom of Gordon } \\
\text { sand at } 1,985 \text { feet. } \\
\text { Gas at } 2,063-2,073 \\
\text { feet. } \\
\text { Gas at } 2,116 \text { feet. }\end{array}$ \\
\hline 122 & Michael No. 1. & .... do............. & 1,055 & $\begin{array}{l}\text { Hundred - f o ot } \\
\text { sand. } \\
\text { Fourth sand.... }\end{array}$ & $\begin{array}{l}1,684 \\
2,002\end{array}$ & $\ldots . .$. & $\begin{array}{l}\text { Oil at } 1,724 \text { feet. } \\
\text { Gas at } 2,040 \text { feet. }\end{array}$ \\
\hline 123 & Leech No. 2.... & $\begin{array}{c}\ldots . . \text { do............ } \\
.\end{array}$ & 1,115 & $\begin{array}{l}\text { Hundred - f o ot } \\
\text { sand. } \\
\text { Fourth sand... }\end{array}$ & $\begin{array}{l}1,715 \\
2,064\end{array}$ & 120 & $\begin{array}{l}\text { Depth of well, } 2,115 \\
\text { feet; oil at } 1,725 \text { and } \\
1,760 \text { feet; gas at }\end{array}$ \\
\hline 124 & A. P. Cole No. 3 & ....do............ & 738 & $\begin{array}{l}\text { Big Injun sand.. } \\
\text { Squaw sand.... } \\
\text { Hundred - fo ot } \\
\text { sand. } \\
\text { Gordon sand.... } \\
\text { Fourth sand.... } \\
\text { Fifth sand..... }\end{array}$ & $\begin{array}{r}627 \\
926 \\
1,343 \\
1,588 \\
1,604 \\
1,730\end{array}$ & $\begin{array}{l}189 \\
108\end{array}$ & $\begin{array}{l}\text { Depth of well, } 1,777 \\
\text { feet. } \\
\text { Oil at } 1,370 \text { feet. } \\
\text { Gas at } 1,598 \text { feet. }\end{array}$ \\
\hline 125 & $\begin{array}{l}\text { H a m i l t o n } \\
\text { heirs No. } 1 .\end{array}$ & $\ldots .$. do............ & 727 & $\begin{array}{l}\text { Salt sand....... } \\
\text { H und re d-foot } \\
\text { sand. } \\
\text { Thirty-footsand } \\
\text { Gordon sand.... } \\
\text { Fifth sand..... }\end{array}$ & $\begin{array}{l}1,181 \\
1,321 \\
1,490 \\
1,580 \\
1,729\end{array}$ & $\begin{array}{r}99 \\
114 \\
\cdots \\
\cdots 3\end{array}$ & $\begin{array}{l}\text { Depth of well, } 1,782 \\
\text { feet. } \\
\text { Gas at 1,585 feet; } \\
\text { more gas at } 1,590\end{array}$ \\
\hline 126 & Bragdon........ & J.H. Galey et al. . & 720 & $\begin{array}{l}\text { Sand.......... } \\
\text { Hundred-foot } \\
\text { sand. } \\
\text { Sand........... } \\
\text { Sand, pebbly... }\end{array}$ & $\begin{array}{r}425 \\
1,327 \\
1,619 \\
1,771\end{array}$ & $\begin{array}{r}5 \\
122 \\
\\
31 \\
10\end{array}$ & $\begin{array}{l}\text { Salt water. } \\
\text { Gas and oil at } 1,388 \\
\text { feet. } \\
\text { Gas. } \\
\text { Oil, show. }\end{array}$ \\
\hline 127 & $\begin{array}{c}\text { Pressed Steel } \\
\text { Car Co. No.3. }\end{array}$ & $\begin{array}{l}\text { Pressed SteelCar } \\
\text { Co. }\end{array}$ & 732 & $\begin{array}{l}\text { Big Injun sand.. } \\
\text { Salt sand........ } \\
\text { Flundred-foot... } \\
\text { Gordon sand (?). } \\
\text { Fourth sand.... } \\
\text { Fifth sand...... }\end{array}$ & $\begin{array}{r}590 \\
1,250 \\
1,360 \\
1,600 \\
1,699 \\
1,750\end{array}$ & $\begin{array}{r}420 \\
\cdots \cdots \\
\cdots \cdots \\
25 \\
35 \\
35\end{array}$ & Show of oil at $1, \dot{780}$ \\
\hline 128 & $\begin{array}{c}\text { Pressed } \\
\text { Car Co. No. } 1 . \\
.\end{array}$ & .....do............ & 731 & $\begin{array}{l}\text { Big Injun sand.. } \\
\text { Squaw sand..... } \\
\text { Salt sand....... } \\
\text { Hundred-foot... } \\
\text { Thirty-foot sand } \\
\text { Gordon sand.... } \\
\text { Fourth sand.... }\end{array}$ & $\begin{array}{r}585 \\
730 \\
1,013 \\
\\
1,384 \\
1,551 \\
1,601 \\
1,715\end{array}$ & $\begin{array}{r}105 \\
165 \\
\cdots \cdots \\
96 \\
30 \\
79 \\
7\end{array}$ & $\begin{array}{l}\text { Ieel. } \\
\text { Water at } 1,250 \text { and } \\
1,263 \text { feet. } \\
\text { Water at } 1,440 \text { feet. } \\
\text { Gas. }\end{array}$ \\
\hline 129 & Nichol No. 3... & S. D. Robison.... & 1,098 & $\begin{array}{l}\text { Injun sand...... } \\
\text { Squaw sand..... } \\
\text { Hund red-foot } \\
\text { sand. } \\
\text { Thirty-footsand }\end{array}$ & $\begin{array}{l}1,005 \\
1,405 \\
1,774 \\
1,930\end{array}$ & $\begin{array}{c}275 \\
106\end{array}$ & $\begin{array}{l}\text { Depth of well, } 2,205 \\
\text { feet. }\end{array}$ \\
\hline
\end{tabular}


Partial records of deep wells in Robinson and Stowe townships, Allegheny County, Pa.Continued.

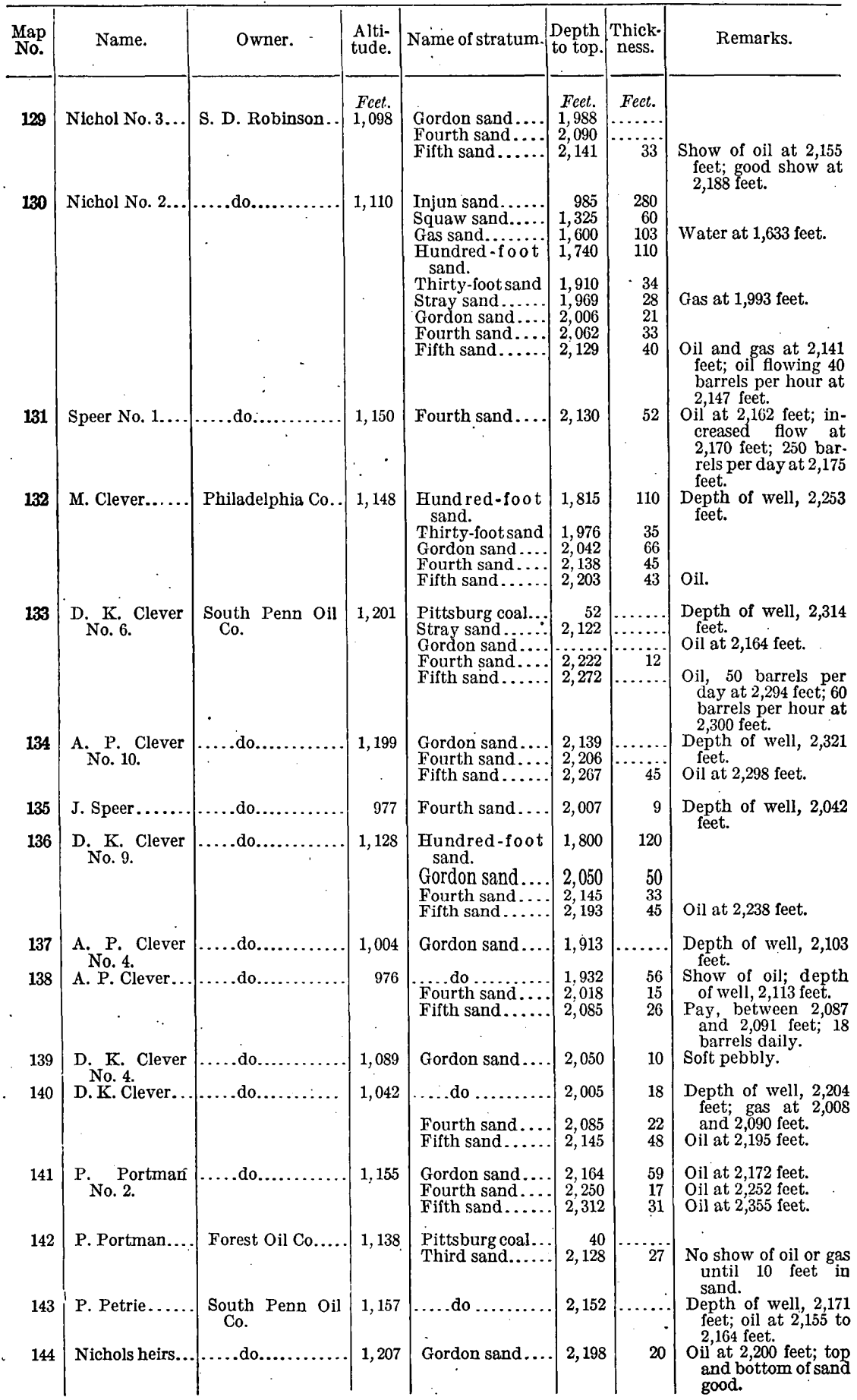


Partial records of deep wells in Robinson and Stowe townships, Allegheny County, Pa.Continued.

\begin{tabular}{|c|c|c|c|c|c|c|c|}
\hline $\begin{array}{l}\text { Map } \\
\text { No. }\end{array}$ & Name. & Owner. & $\begin{array}{l}\text { Alti- } \\
\text { tude. }\end{array}$ & Name of stratum. & $\begin{array}{l}\text { Depth } \\
\text { to top. }\end{array}$ & $\begin{array}{l}\text { Thick- } \\
\text { ness. }\end{array}$ & Remarks. \\
\hline 145 & John Palmer.. & South Penn Oil & $\begin{array}{l}\text { Feet. } \\
1,192\end{array}$ & Fifth sand... & $\begin{array}{r}\text { Feet. } \\
2,379\end{array}$ & $\begin{array}{r}\text { Feet. } \\
11\end{array}$ & Depth of well, 2,390 \\
\hline 140 & Adams No. 2... & ..... dio............. & 1,165 & ..... do ... & $\begin{array}{c}2,260 \\
. .\end{array}$ & & $\begin{array}{l}\text { Depth of well, } 2,270 \\
\text { feet; oil at } 2,265\end{array}$ \\
\hline 147 & A. A. Daugh- & .....do........... & 1,156 & Fifth sand...... & 2,299 & 10 & Depth of wèll, 2,309 \\
\hline 148 & L. Shaffer...... & .....do.. & 1,153 & $\begin{array}{l}\text { Pittsburg coal... } \\
\text { Salt sand........ } \\
\text { Big Injun sand.. } \\
\text { Hundred - f o o t } \\
\text { sand. }\end{array}$ & $\begin{array}{r}73 \\
1,000 \\
1,240 \\
1,970\end{array}$ & $\begin{array}{r}208 \\
250 \\
66\end{array}$ & $\begin{array}{l}\text { leet. } \\
\text { Salt water at } 1,050 \\
\text { feet. }\end{array}$ \\
\hline & & & & $\begin{array}{l}\text { Gordon sand.... } \\
\text { Fifth sand...... }\end{array}$ & $\begin{array}{l}2,183 \\
2,313\end{array}$ & $\begin{array}{l}25 \\
18\end{array}$ & Gas and oil at $\dot{2,317}$ \\
\hline 149 & H. Shaffer... & ....do.... & 1,076 & ....do . . & 2,215 & 29 & \\
\hline 150 & A. Tidball.... & & 1,140 & $\begin{array}{l}\text { Pittsburg coal... } \\
\text { Fifth sand....... }\end{array}$ & $\begin{array}{r}65 \\
2,304\end{array}$ & $\dddot{2} \ddot{4}$ & Oil at 2,308 feet; poor \\
\hline 151 & Kelso No. 3... & J. J. Showalter... & 1,155 & .... do ... & 2,297 & 4 & \\
\hline
\end{tabular}

PITTSBURG AND VICINITY.

Under this heading is included that portion of the city of Pittsburg lying west of the eightieth meridian, and the townships and boroughs of Chartiers, Greentree, Union, and West Liberty, south of Ohio River, and a large portion of Bellevue and Allegheny townships and the southern part of Ross Township, north of the river.

Within this area a large number of deep wells have been drilled. Some of these wells have furnished varying amounts of both oil and gas, but no very extensive fields have been developed. Though Pittsburg is the center of one of the most important manufacturing districts in the United States, the area immediately adjacent to this city is of little value as regards the production of oil and gas, and will therefore be given little attention in this report. Many manufacturers in this city have attempted to secure cheap fuel for their plants by sinking deep wells on their properties in search of natural gas. In most of these wells gas was encountered at one or more horizons, often in sufficient quantities to justify the expense of the effort. In many wells, however, salt water accompanied the gas or was found to be so closely associated with it that the supply diminished rapidly and the wells were soon abandoned. In gathering material for the present report no attempt was made to locate on the map the abandoned holes nor to establish the position of many of those that are still producing, since the time and money necessary to do this work thoroughly were not available, and it is doubtful if the geologic and economic value of the material thus obtained would in any case justify the expenditure necessary to secure it. 
A number of records of wells drilled within the city of Pittsburg have been published by the Pennsylvania State Geological Survey, ${ }^{a}$ together with descriptions of the locations of these wells, to which the reader is referred. Most of these wells have long since been abandoned and in most cases their locations have been obliterated, so that their positions on the map can now be only approximated. Some of the geologic facts brought out in the earlier reports are of sufficient importance to justify reprinting here.

In 1884-85 Messrs. Jones \& Laughlin, of the American Iron $\&$ Steel Works, drilled a well ${ }^{a}$. No. 156 on map) on their property on the south bank of Monongahela River and on the east side of Twenty-sixth Street, twenty-fifth ward, Pittsburg. This well was sunk to a depth of 3,000 feet, and encountered shows of gas at 360 , $510,1,525$ to $1,618,1,789$, and 1,804 feet below the surface. The first three of these shows were accompanied by salt water and were soon exhausted. A good flow of gas was encountered at 1,789 feet and a better one at 1,804 feet from what is very probably the Gordon sand. The last flow came from a pebbly pay streak not over 2 feet in thickness. This well was cased to a depth of 1,720 feet and was subsequently filled up to a depth of 1,870 feet; tubing was inserted to pump off the salt water which accumulated with the gas and showed that some of the sands between 1,720 and 1,870 feet were also water bearing. The gas at 1,525 to 1,618 feet comes from either the Murrysville sand or the Hundred-foot sand. It was reported as foul smelling and as being accompanied by considerable quantities of salt water. This water made its appearance as soon as the sand was touched by the drill. When the well was 10 feet in the sand the water stood 400 feet deep and a day later flowed 5 gallons per minute from the mouth of the well. This water had a temperature of $66.2^{\circ} \mathrm{F} .5$ feet below the mouth of the well, with a specific gravity of 1.075 at $59^{\circ} \mathrm{F}$. In this well a small amount of salt water was encountered at a depth of 2,400 feet, which is probably more than 450 feet below the Fifth sand. This is the greatest depth at which water has been reported within the Carnegie quadrangle.

In May, 1885, Messrs. Jones \& Laughlin completed their second well, about 600 yards east of No. 1. This well found a "pocket" of gas in a coal seam at a depth of 480 feet, and andther at 710 feet, which had sufficient pressure to cause the water to flow from the hole. The salt-water sand, which is either the Murrysville or the Hundredfoot, was struck in this well at a depth of 150 feet. At 1,517 feet, 400 feet of water stood in the hole. When a depth of 1,535 feet was reached ${ }^{b}$ the muddy, foaming water began to flow over the mouth of the well, though there was hardly sufficient gas to ignite. At 
1,551 feet the water flowed intermittently, sometimes resting for several hours and settling down 50 feet or more below the casing head. At 1,585 feet the water gained new strength and increased with each screw down to the bottom of the sand at a depth of 1,606 feet. "Temperature of water" ${ }^{\prime} 68^{\circ} \mathrm{F}$.; specific gravity at $59^{\circ} \mathrm{F} .=$ 1.0725. Water very clear. One pint of water (United States standard) at $59^{\circ} \mathrm{F}$. $\left(15^{\circ} \mathrm{C}\right.$.) weighs 1 pound 1 ounce 13 drams. One pint of water (United States standard) yields on evaporation to perfect dryness 1 ounce, 13 drams of salty residue."

This well was cased to 1,610 feet, completely shutting off the salt water mentioned above. . No salt water or gas occurs from 610 to 1,698 feet, where a small flow of gas was found in what is probably the Nineveh Thirty-foot sand. At 1,705 feet a small quantity of salt water was encountered. At a depth of 1,792 feet a large flow of gas was struck in the top of what is considered to be the Gordon sand, which blew out the salt water and drillings, but the well later filled up 600 feet with water, which upon being agitated by the tools was blown from the well by the gas. . It is not known positively whether this water came from the Nineveh Thirty-foot or the Gordon sand, but it appears to have come from both.

The same salt-water conditions were found to obtain in many of the wells drilled in this area. Boyd Hill well, drilled in 1876-77, was located at the south end of Boyd Hill, opposite the Pittsburg Steel Works, on the north side of Monongahela River. In this well ${ }^{b}$ the great salt water sand of this area, which is probably to be correlated either with the Murrysville or the upper portion of the Hundred-foot sand, was struck at a depth of 1,585 feet; it is 112 feet thick. This sand was found to be completely saturated with salt water under pressure sufficient to cause it to flow out of the well mouth at the rate of 3,000 to 4,000 barrels a day. It contained 11 per cent salt, and it is said that 348 gallons of water made 280 pounds of salt and 60 pounds of "bittern." It contained 0.31 per cent bromine and is said to have had a "strong fishy smell." It is said that the water from this well did not spout intermittently, as from gas pressure, but flowed a steady stream over the casing haad. In this well a show of oil and gas was found in a loose gray sand at 2,117 feet, which is probably the Fifth sand. Attention should also be called to the fact that salt water was encountered in this well at a depth of 587 feet, which is only about 430 feet below low-water mark in the Ohio River at this place. This salt-water sand outcrops at the surface of the Ohio River in the vicinity of Freedom only a few miles down the river from Pittsburg, and is reported as a fresh-water sand at many intermediate points. A complete section of this well (No. 157) is shown on Plate II (p. 11).

a From notes of Mr. F. T. Cretton, then chemist for Jones \& Laughlin steel plant.

$b$ For complete description of this well see vol. 5, Second Geol. Survey Pennsylvania, Appendix E, p. 217. 
The foregoing statement of the salt-water conditions in the sands of this vicinity has been made not on account of any special economic value being attached to these facts, but because of the possible use to which they may be put in theoretical studies of oil and gas accumulation. Similar conditions to those described above are found in many of the wells drilled within the city. One of the deepest of these wells was put down for brine and gas by the John A. Beck Salt Co. on the property of that company, north side of Pittsburg. A complete record of this well (No. 159) is given on pages 11-12 of this report. This well penetrated to a depth of $4,089 \frac{1}{2}$ feet. No mention is made in the record of the salt-water conditions in it nor of the relative amount and closed pressure of the gas which was found at 1,655 and 1,930 feet from the top in what are probably the Nineveh Thirty-foot and Fifth sands, respectively.

Well No. 160 obtained gas in the Fifth sand. In No. 161 the Hundred-foot sand flowed oil and gas from a 10-foot pay streak located 10 feet below the top of the sand. A small amount of gas also came from the Nineveh Thirty-foot sand, 5 feet below the top, and a little from a pay streak 12 feet in the Gordon sand. The strong flow, however, comes from a 9-foot pay streak in the Fifth sand, 20 feet below the top.

Bellevue oil and gas field.-Only the southern part of the Bellevue oil and gas field is included in the Carnegie quadrangle. This field at one time covered most of the territory upon which Bellevue now stands and extended northwest for some distance into the Sewickley quadrangle. Oil and gas were found principally in the Hundred-foot and the Nineveh Thirty-foot sands. Some of the early wells in this field are said to have produced at the rate of several hundred barrels per day, but these have long since been exhausted and abandoned or else reduced to a production of only a few barrels per day. Many of the locations of these wells were obliterated by the rapid subsequent growth and improvements of the town. Within the last 10 years a number of wells have been sunk in the extension northeast of the Nineveh Thirty-foot sand pool. Some of these wells are still pumping, and are shown on the map southeast of well No. 162. This well found two pay streaks containing oil with some salt water in the Hundred-foot sand; these are 34 and 41 feet below the top of the sand. Gas was also encountered in the Nineveh Thirty-foot at a depth of 6 feet in the sand. The Fourth and Fifth sands are here 25 and 17 feet thick, respectively.

In the vicinity of well No. 163 on the Peter Ivory farm a small pool of oil and gas was found in the Hundred-foot sand, but the supply was quickly exhausted, and the wells were soon abandoned. The pay streak in this sand is from 33 to 35 feet below the top of the sand. Salt water in varying amounts accompanies the oil and gas in this 
field. Spirit-level lines were run to most of the wells in this field, and their elevations above sea level were determined, but a diligent search for records proved unsuccessful, and the data relative to them are therefore very meager.

Chartiers oil and gas field.-This field is located on Chartiers Creek, about 1 mile southwest of McKees Rocks. It is partly in Stowe and partly in Chartiers townships, and in reality consists mainly of a northeast extension of the Gordon sand pool from the vicinity of Moon Run. Though most of the oil in this field comes from the Gordon sand, both oil and gas have been obtained from the Hundredfoot sand.

Well No. 2 on the Luke May farm (No. 154) found the Gordon sand 30 feet thick, with the top of the first pay streak 15 feet in the sand. In well No. 1, on the same farm (No. 153), the Hundred-foot sand carries oil 15 feet below the top, with two pay streaks in the Gordon sand 10 and 19 feet below the top. In well No. 155 on the Petrie farm the pay streak in the Hundred-foot sand is 36 feet below the top. No mention is made in the record of a pay streak in the Gordon sand, which is here 54 feet in thickness and is doubtless productive. In other wells of this field, on the McKee heirs, Johnston, and Scully farms, most of which are now owned by the Granite Improvement Co., the pay streak in the Gordon sand varies from 4 to more than 17 feet below the top, but the records furnish no data relative to the thickness and the amount of oil and gas secured from the sand.

Southeast of the Chartiers field the sands appear to be unusually barren of both oil and gas. Two or three small gas wells in the Fifth sand southeast of Ingram and Idlewood seem to be all that have proved even partly successful. Diligent inquiry' in the field failed to discover any deep holes in either Union or West Liberty boroughs, though it seems hardly possible that an area of this size, situated so near Pittsburg, could have escaped the inquisitiveness of the operator.

Records of wells in Pittsburg and vicinity.-The following table gives records of wells in and near Pittsburg:

Partial records of deep wells in Pittsburg and vicinity.

\begin{tabular}{|c|c|c|c|c|c|c|c|}
\hline $\begin{array}{l}\text { Map } \\
\text { No. }\end{array}$ & Name. & Owner. & $\begin{array}{l}\text { Alti- } \\
\text { tude. }\end{array}$ & Name of stratum. & $\begin{array}{l}\text { Depth } \\
\text { to top. }\end{array}$ & $\begin{array}{c}\text { Thick- } \\
\text { ness. }\end{array}$ & Remarks. \\
\hline 152 & McKee heirs... & $\begin{array}{l}\text { South Penn Oil } \\
\text { Co. }\end{array}$ & $\begin{array}{l}\text { Feet. } \\
748\end{array}$ & Gordon sand .... & $\begin{array}{l}\text { Fect. } \\
1,722\end{array}$ & $\begin{array}{c}\text { Feet. } \\
\cdots \cdots\end{array}$ & $\begin{array}{l}\text { Oil at } 1,728 \text { to } 1,730 \\
\text { feet; depth of well, } \\
1,750 \text { leet. }\end{array}$ \\
\hline 153 & $\begin{array}{l}\mathrm{Luke} \text { M a y } \\
\text { No. } 1 .\end{array}$ & A. G. Davis...... & 759 & $\begin{array}{l}\text { H u n d re d-foot. } \\
\text { sand. } \\
\text { Third sand...... }\end{array}$ & $\begin{array}{l}1,525 \\
1,766\end{array}$ & ? & $\begin{array}{l}\text { Depth of well, } 1,8 c 0 \\
\text { feet; oil at } 1,540 \\
\text { feet; oil at } 1,776 \text { and } \\
1,785 \text { feet. }\end{array}$ \\
\hline 154 & $\begin{array}{l}\text { I uke May } \\
\text { No. } 2 \text {. }\end{array}$ & .....do... & $\cdots$ & $\begin{array}{l}\text { H u nd red-foot } \\
\text { sand. } \\
\text { Third sand...... }\end{array}$ & $\begin{array}{l}1,521 \\
1,739\end{array}$ & $\begin{array}{r}\cdots \cdots \\
30\end{array}$ & $\begin{array}{l}\text { Depth of well, } 1,774 \\
\text { feet. } \\
\text { Pay at } 1,754 \text { feet. }\end{array}$ \\
\hline
\end{tabular}


Partial records of deep wells in Pittsburg and vicinity-Continued.

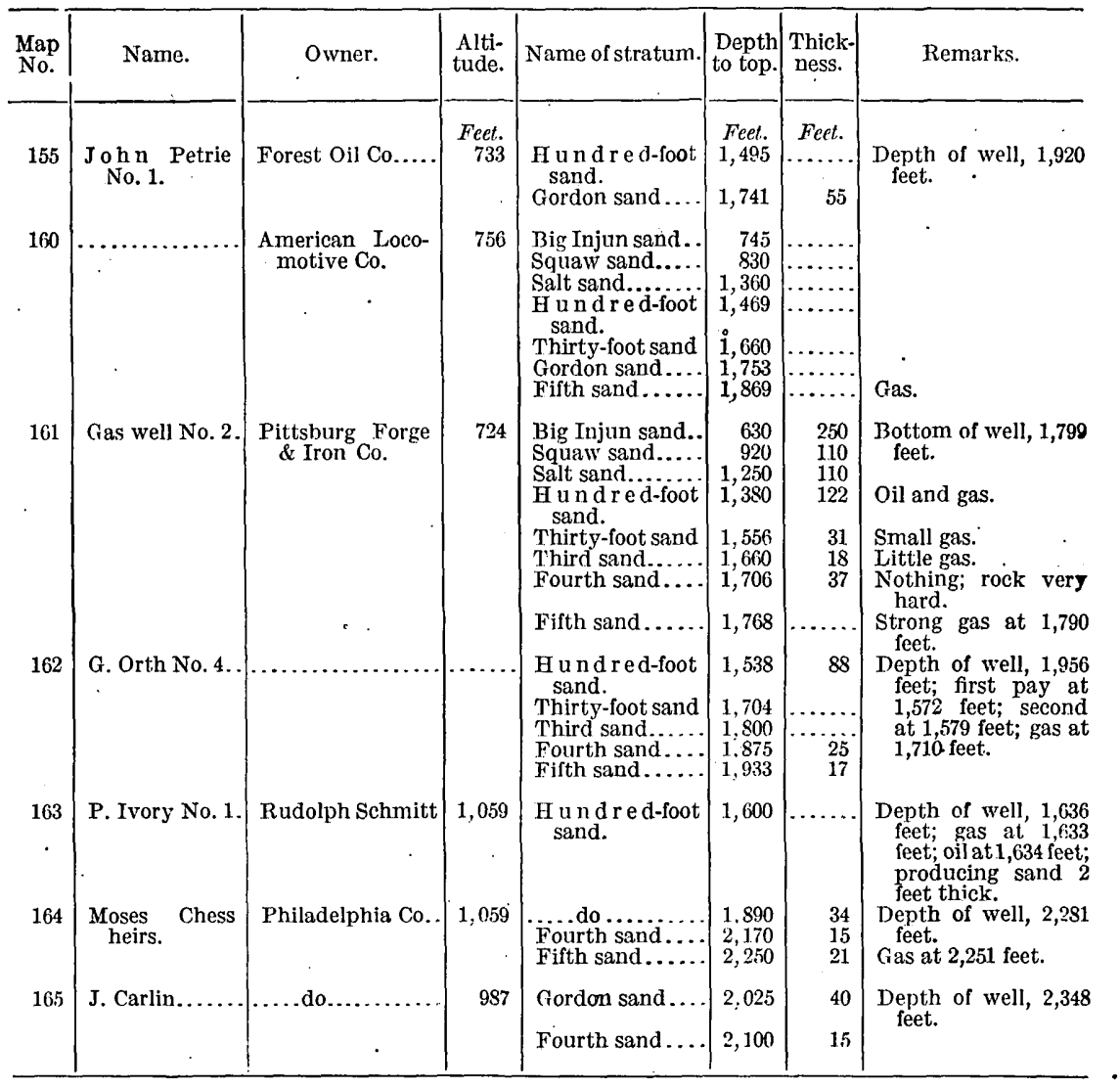

\section{COLLIER, SCOTT, AND BALDWIN TOWNSHIPS, ALLEGHENY COUNTY.}

These three townships form a tier across the central portion of the quadrangle east of North Fayette and South Fayette townships.

The oil-producing territory of these townships appears to be limited in Collier Township to a small area in the extreme northwestern part of the township included in the McDonald field and a few scattered wells near Rennerdale, and to a small pool at Woodrille, on the border of Scott and Collier townships. Small pools of gas, none of great importance, occur at a number of places, though ogcasionally a good flow is secured. Both the oil and the gas pools are erratic in occurrence, due apparently to the varying condition of the sands and pay streaks in the different places.

McDonald oil and gas field.- The Fifth sand oil pool of the McDonald field extends across the northwest corner of Collier Township. The best wells were found in the southern part of this productive area 
on the John Mertz farm, one of which showed an initial flow of 1,400 barrels per day. This is the best well yet found in Collier Township. In a few wells the Hundred-foot sand is said to furnish a little gas. So far as could be learned, the Gordon and the Fourth sands, although somewhat below normal thickness, are fairly constant, but contain no oil, gas, or salt water. The Fifth sand is said to furnish a small amount of salt water in the northern portion, but toward the southwest, where oil production was greatest, no water is found in this sand. The Hundred-foot sand appears to be water bearing throughout the entire area.

The thickness of the Fifth sand is fairly uniform over this part of the McDonald field. In wells Nos. 167, 168, and 169 it is 24,40 , and 27 feet, respectively. The pay streaks in wells Nos. 166, 167, and 169 are 14, 9, and 18 feet, respectively, below the top, in No. 167 both oil and gas being found at 9 feet in the sand.

The oil wells in the vicinity of Rennerdale appear to produce principally from the Hundred-foot sand, though in some of them the oil is said to come from the Gordon sand. In well No. 170 the oil occurs in a pay streak of the Hundred-foot sand 51 feet below the top. This pay streak is said also to furnish more or less salt water with the oil.

Small pools of gas represented by one or two producing wells occur at various places in Collier Township. The elevations above sea level of most of these wells were determined and their positions were indicated on the map (Pl. IV), but few records and very little other data relative to them could be secured. Most of these wells were drilled for oil, but proving to be failures for that purpose were utilized for gas wherever the supply justified the cost of keeping them attached to a pipe line. The pools in all the sands of this vicinity seem to be small, and for this reason the territory does not appear to justify careful exploitation for its gas supply, the chances being that more money would be expended in drilling wells than would be obtained from the sale of the gas.

In well No. 171 gas was found in the Nineveh Thirty-foot sand; in well No. 172 the pool is in the Fourth sand. No mention is made of the producing sand in the record of well No. 173. It should be noted, however, that the sands in this well have the following thickness: Hundred-fo't, 110 feet; Nineveh Thirty-foot, 22 feet; Gordon, 45 feet; Fourth, 20 feet; and Fifth, 13 feet-only the Fifth sand being below normal thickness. 
The following table gives partial records of wells in Collier Township:

Partial records of deep wells in Collier Township, Allegheny County, Pa.

\begin{tabular}{|c|c|c|c|c|c|c|c|}
\hline $\begin{array}{l}\text { Map } \\
\text { No. }\end{array}$ & Name. & Owner. & $\begin{array}{l}\text { Alti- } \\
\text { tude. }\end{array}$ & Name of stratum. & $\begin{array}{l}\text { Depth } \\
\text { to top. }\end{array}$ & $\begin{array}{l}\text { 'Thick- } \\
\text { ness. }\end{array}$ & Remarks. \\
\hline 166 & J. Cowan No.4. & Forest Oil Co.... & $\begin{array}{l}\text { Feet. } \\
1,204\end{array}$ & $\begin{array}{l}\text { Pittsburg coal... } \\
\text { Fifth sand...... }\end{array}$ & $\begin{array}{r}\text { Feet. } \\
120 \\
2,362\end{array}$ & Feet. & $\begin{array}{l}\text { Depth of well, } 2,382 \\
\text { feet. } \\
\text { Oil at } 2,377 \text { feet. }\end{array}$ \\
\hline 168 & $\begin{array}{l}\text { A. Mertz...... } \\
\text { McMichael.... }\end{array}$ & $\begin{array}{l}\text { South Penn Oil } \\
\text { Co. } \\
\text { J. J. Showalter... }\end{array}$ & $\begin{array}{l}1,162 \\
1,009\end{array}$ & 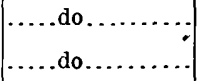 & $\begin{array}{l}2,316 \\
2,164\end{array}$ & $\begin{array}{l}24 \\
40\end{array}$ & $\begin{array}{l}\text { Gas and oil at } 2,325 \\
\text { feet. }\end{array}$ \\
\hline 169 . & $\begin{array}{l}\text { Louisa Kelso } \\
\text { No. } 2 .\end{array}$ & Forest Oil Co... & 1,075 & .....do..... & 2,238 & 27 & $\begin{array}{l}\text { Oil and gas at } 2,256 \\
\text { feet; } 20 \text { barrels per } \\
\text { hour per day from } \\
\text { Fifth sand. }\end{array}$ \\
\hline 76 & $\begin{array}{l}\text { Mary Gordon } \\
\text { No. } 1 .\end{array}$ & - & 1,047 & $\begin{array}{l}\text { Pittsburg coal... } \\
\text { Salt sand...... } \\
\text { Hundred - f o o t } \\
\text { sand. } \\
\text { Thirty-foot sand. } \\
\text { Gordon Re ed } \\
\text { sand. } \\
\text { Gordon White } \\
\text { sand. } \\
\text { Fourth sand.... } \\
\text { Fifth sand...... }\end{array}$ & $\begin{array}{r}68 \\
960 \\
2,005 \\
2,122 \\
2,190 \\
2,211 \\
2,285 \\
2,340\end{array}$ & & $\begin{array}{l}\text { Depth of well, } 2,350 \\
\text { feet. }\end{array}$ \\
\hline 170 & A. Bo. 1. Miller & & 896 & $\begin{array}{l}\text { Big Injun sand. } \\
\text { Hundred - f o o t } \\
\text { sand. }\end{array}$ & $\begin{array}{r}970 \\
1,797\end{array}$ & & $\begin{array}{l}\text { Depth of well, } 1,859 \\
\text { feet; gas at } 1,225 \\
\text { feet; oil at } 1,849\end{array}$ \\
\hline 171 & J. A. Ewing. . & Philadelphia Co. & 987 & Thirty-foot sand & $\begin{array}{l}1,845 \\
2,009\end{array}$ & 9 & Gas. \\
\hline 172 & J. Clark. . & 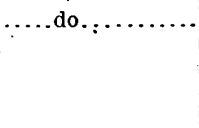 & 801 & $\begin{array}{l}\text { Hundred - f o o t } \\
\text { sand. } \\
\text { Gordon } s \text { t r a y } \\
\text { sand. } \\
\text { Fourth sand.... }\end{array}$ & $\begin{array}{l}1,765 \\
1,975 \\
2,100\end{array}$ & $\begin{array}{r}100 \\
50 \\
15\end{array}$ & $\begin{array}{l}\text { Depth of well, } 2,115 \\
\text { feet.. } \\
\text { Producing. }\end{array}$ \\
\hline 173 & $\begin{array}{c}\text { F. B. Nimick. } \\
\text { : }\end{array}$ & ....do............ & 8,504 & $\begin{array}{l}\text { Big Injun sand. } \\
\text { Squaw sand.... } \\
\text { Hundred - f o o } t \\
\text { sand. } \\
\text { Thirty-foot sand } \\
\text { Gordon sand.... } \\
\text { Fourth sand.... } \\
\text { Fifth sand...... }\end{array}$ & $\begin{array}{l}1,120 \\
1,485 \\
1,842 \\
\\
2,010 \\
2,080 \\
2,160 \\
2,220\end{array}$ & $\begin{array}{r}300 \\
80 \\
110 \\
\\
22 \\
45 \\
20 \\
13\end{array}$ & $\begin{array}{l}\text { Depth of well, } 2,255 \\
\text { feet. }\end{array}$ \\
\hline 174 & $\begin{array}{l}\text { Allegheny } \\
\text { County Home } \\
\text { No. } 2 \text {. }\end{array}$ & 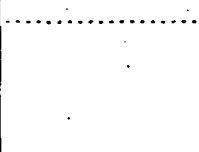 & 808 & $\begin{array}{l}\text { Salt sand........ } \\
\text { Big Injun sand.. } \\
\text { Squaw sand..... } \\
\text { Hundred - f o o } t \\
\text { sand. } \\
\text { Thirty-foot sand }\end{array}$ & $\begin{array}{r}900 \\
1,140 \\
1,420 \\
1,855 \\
2,015\end{array}$ & $\begin{array}{r}145 \\
240 \\
130 \\
95 \\
50\end{array}$ & $\begin{array}{l}\text { Depth of well, } 2,100 \\
\text { feet. } \\
\text { Oil and water at } 1,910 \\
\text { feet. } \\
\text { Oil at } 2,025 \text { feet; gas }\end{array}$ \\
\hline 175 & Jno. McKeown & Philadelphia Co.: & 897 & $\begin{array}{l}\text { Salt sand........ } \\
\text { Big Injun sand.. } \\
\text { Hundred - f o o } t \\
\text { sand. }\end{array}$ & $\begin{array}{l}1,023 \\
1,155 \\
1,930\end{array}$ & $\begin{array}{r}92 \\
300 \\
210\end{array}$ & $\begin{array}{l}\text { Depth of well, } 2,140 \\
\text { feet. }\end{array}$ \\
\hline
\end{tabular}

Woodville oil and gas field.-In the Woodville field the Nineveh Thirty-foot sand produces most of the oil and gas, though the Hundred-foot sand furnishes some oil and gas, and good shows of gas are reported from the Salt sand. Well No. 174, on the property of the Allegheny County Home, was drilled in 1907. In this well the Hundred-foot sand is 95 feet thick, with the pay streak containing oil and salt water 55 feet below the top of the sand. The Nineveh Thirtyfoot sand is here 50 feet thick, with gas in the top of the sand and oil 10 feet below. No record could be secured of the Joseph Campbell 
No. 1 well, located about 200 feet southwest of the railroad station at Woodville. This is said to have been the pioneer well in this field and to have produced gas for four years from the Gordon sand, and later to have begun flowing oil at the rate of 100 barrels per day from that sand. It appears to be regarded as a freak well since others, drilled within 100 feet of it, are said to have furnished little or no oil or gas from the Gordon sand. Hearsay data must, however, be accepted with due allowance for such discrepancies as are likely to occur in evidence of this nature. In well No. 178 the Nineveh Thirtyfoot sand furnishes oil from a pay streak 6 feet below the top, and in No. 179 the same sand was found to contain gas and oil 19 and 23 feet, respectively, below the top. In well No. 176 the Salt sand was found to contain a small amount of gas at a depth of 960 feet with salt water below, the Nineveh Thirty-foot sand furnishing both oil and gas at a depth of 2,110 feet. In several wells of this field the Salt sand carries more or less gas at the top with salt water below, which in well No. 185 was under sufficient pressure to send a stream of salt water over the top of the derrick. The Hundred-foot sand in this well (No. 185) is over 110 feet thick; it furnished a small amount of oil, gas, and salt water near the bottom. In this well the Hundred-foot sand is described as being reddish and somewhat limy; the Nineveh Thirty-foot sand is hard, reddish, and of poor quality; the Gordon sand seems to be represented only by "slate and shells;" the Fourth sand is only 5 feet thick; and the Fifth sand is 20 feet thick but dry. No salt water was encountered below the Hundred-foot sand. It should be especially noted, however, that salt water entered this well at the rate of 4 barrels per hour from a sandstone only 75 feet from the surface and less than 100 feet below the. Pittsburg coal. Another salt water stratum was struck at 390 feet which furnished 10 barrels per hour. In the oil fields of southwestern Pennsylvania salt water is rarely reported at such shallow depths.

In well No. 177 the Hundred-foot sand is reported to have 25 feet of nice, soft, white sand, with large white pebbles, but to contain no oil or gas and only a little salt water. In this well the Nineveh Thirtyfoot sand is 31 feet thick and furnishes gas. This field is now down to a settled production, furnishing a maximum of a few barrels per day from some of the best wells.

Northeast and east of the Woodville field the Nineveh Thirty-foot, the Hundred-foot, and the Gas sands furnish gas in a number of scattered wells. Careful inquiry, however, failed to locate the records of these wells or to secure other data relative to them.

Castle Shannon gas pool.-In the eastern part of Scott Township, in the vicinity of Castle Shannon, a gas pool of considerable size has been found in the Hundred-foot sand, which here has a thickness of about 100 feet. The gas comes from a pay streak below the "break" in. this sand, in that portion designated farther south as the Fifty-foot 
sand. Farther east, in the vicinity of well No. 181, the Gantz sand is thought to furnish the gas. In well No. 180 gas is also reported from a sand at a depth of 2,324 feet and at a distance of 309 feet below the top of the Gantz or Hundred-foot sands. This sand is considered by drillers to be the Gordon. In well No. 184, on the Boyd farm, this sand is said to have produced several barrels of oil, but the statement could not be verified. Most of the wells in this area were drilled several years ago and a number of them have been exhausted and abandoned.

Records of wells.-The following table gives records of wells in Scott and Baldwin townships:

Partial records of deep wells in Scott and Baldwin townships, Allegheny County, Pa.

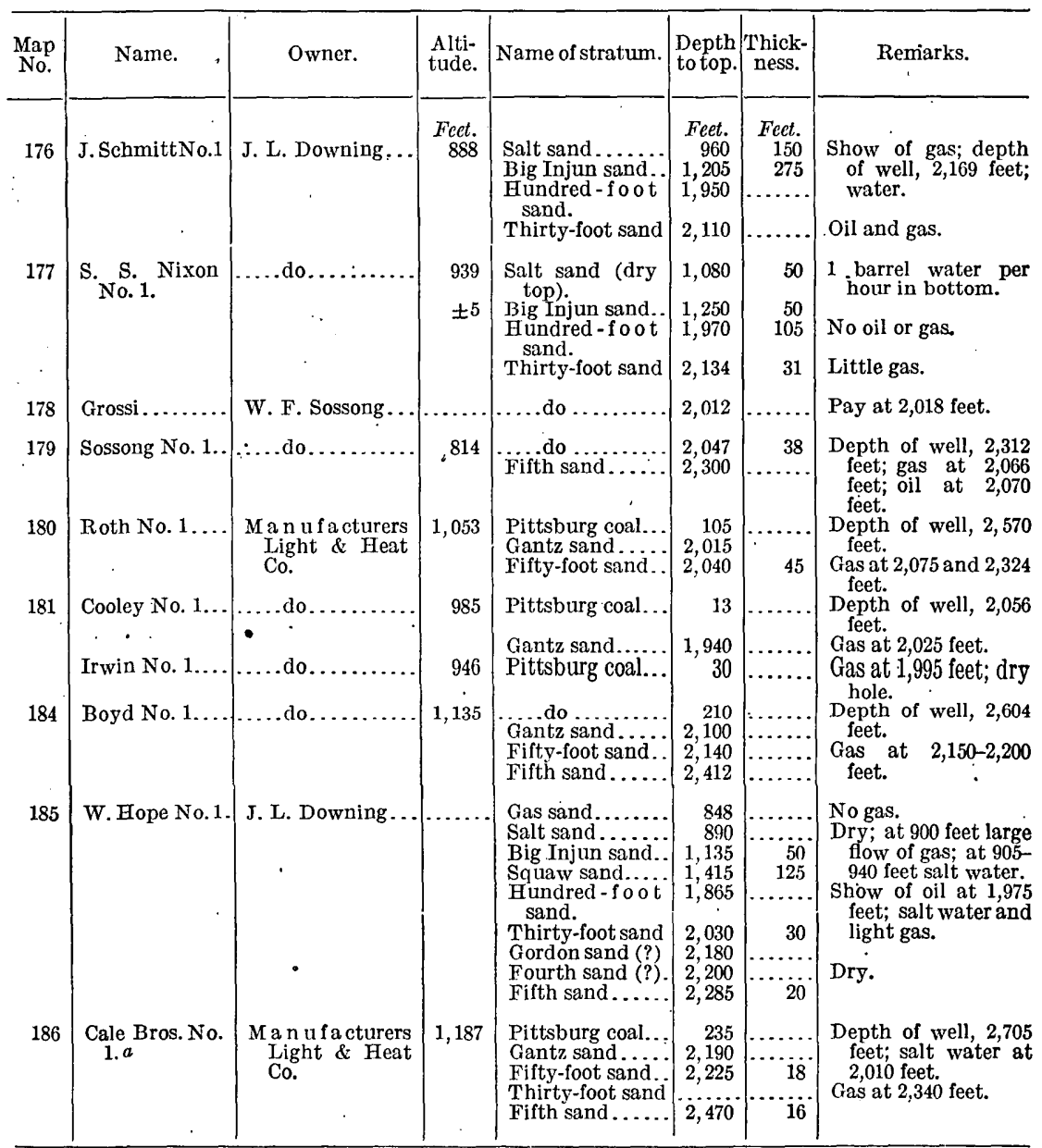

$a$ This well is located about $1 \frac{1}{2}$ miles southeast of No. 181 and one-fourth mile northwest of Whitehal Chapel, about one-half mile off the quadrangle. 
UPPER ST. CLAIR TOWNSHIP, ALLEGHENY COUNTY.

Bridgeville gas field.-The Bridgeville gas field includes superimposed pools of gas in the Hundred-foot, Nineveh Thirty-foot, Gordon, Fourth, and Fifth sands. These pools are each apparently very small and do not form continuous productive areas over the entire field. Each sand in reality contains a series of small pools which apparently have very irregular outlines. The field extends into South Fayette Township on the west, and into Collier and Scott townships on the north. Few records of wells in this field were available; the ones obtained indicate that the field occupies the sloping crest of an arch projecting from the east toward the Nineveh syncline. The record of the well on the W. J. Fryer farm, No. 187, shows the Hundredfoot, Nineveh Thirty-foot, Third or Gordon, and Fifth sands to be gas bearing, the pay streaks being $42,2,50$, and 4 feet, respectively, below the top of the sands. In No. 188 only the lower portion of the Hundred-foot sand was found to contain gas, the pay streak being 12 feet below the top. This well was drilled through the Fifth sand. The J. A. Bell No. 1 well (No. 189) found a little gas in the Nineveh Thirty-foot sand, 12 feet below the top, but the main volume came from two thin pay streaks in the. Fourth sand, at the top and 5 feet below the top. The Hundred-foot, the Gordon, and the Fifth sands are of normal thickness in this well, but contain no oil, gas, or salt water. In the Charles Godwin No. 1 well (No. 200) all the sands are present in normal thickness, but only the Nineveh Thirty-foot and the Fifth are gas bearing. The Nineveh Thirtyfoot sand contained only a small amount of gas in the top; the Fifth sand furnished the main supply from a pay streak 2 feet below the top. The utmost irregularity prevails regarding the location of the small pools in each of the sands. Many of these wells have been furnishing gas to the pipe lines for several years, and are said to hold up remarkably in the amount of production.

Records of wells.-The following table gives records of wells in the Bridgeville field:

Partial records of deep wells in the Bridgeville gas field, Upper St. Clair Township, il Allegheny County, Pa.

\begin{tabular}{|c|c|c|c|c|c|c|c|}
\hline $\begin{array}{l}\text { Map } \\
\text { No. }\end{array}$ & Name. & Owner. & $\begin{array}{l}\text { Alti- } \\
\text { tude. }\end{array}$ & Name of stratum. & $\begin{array}{l}\text { Depth } \\
\text { to top. }\end{array} \mid$ & $\begin{array}{c}\text { Thick- } \\
\text { ness. }\end{array}$ & Remarks. \\
\hline 187 & W. J. Fryer'... & Philadelphia Co.. & $\begin{array}{c}\text { Feet. } \\
870(?) \\
\pm 10\end{array}$ & $\begin{array}{l}\text { Salt sand....... } \\
\text { Big Injun sand.. } \\
\text { Hundred - f o o } t \\
\text { sand. } \\
\text { Thirty-foot sand } \\
\text { Third sand...... } \\
\text { Fourth sand.... } \\
\text { Fifth sand...... }\end{array}$ & $\left|\begin{array}{c}\text { Feet. } \\
1,050 \\
1,264 \\
2,005 \\
2,181 \\
2,243 \\
2,322 \\
2,376\end{array}\right|$ & $\begin{array}{r}\text { Fect. } \\
27 \\
142 \\
114 \\
\\
25 \\
58 \\
14 \\
11\end{array}$ & $\begin{array}{l}\text { Depth of well, } 2,424 \\
\text { feet. } \\
\text { Gas at } 2,047 \text { feet. } \\
\text { Gas at } 2,183 \text { feet. } \\
\text { Gas at } 2,293 \text { feet. } \\
\text { Gas at } 2,380 \text { feet. }\end{array}$ \\
\hline
\end{tabular}


Partial records of deep wells in the Bridgeville gas field, Upper St. Clair Township, Allegheny County, Pa.-Continued.

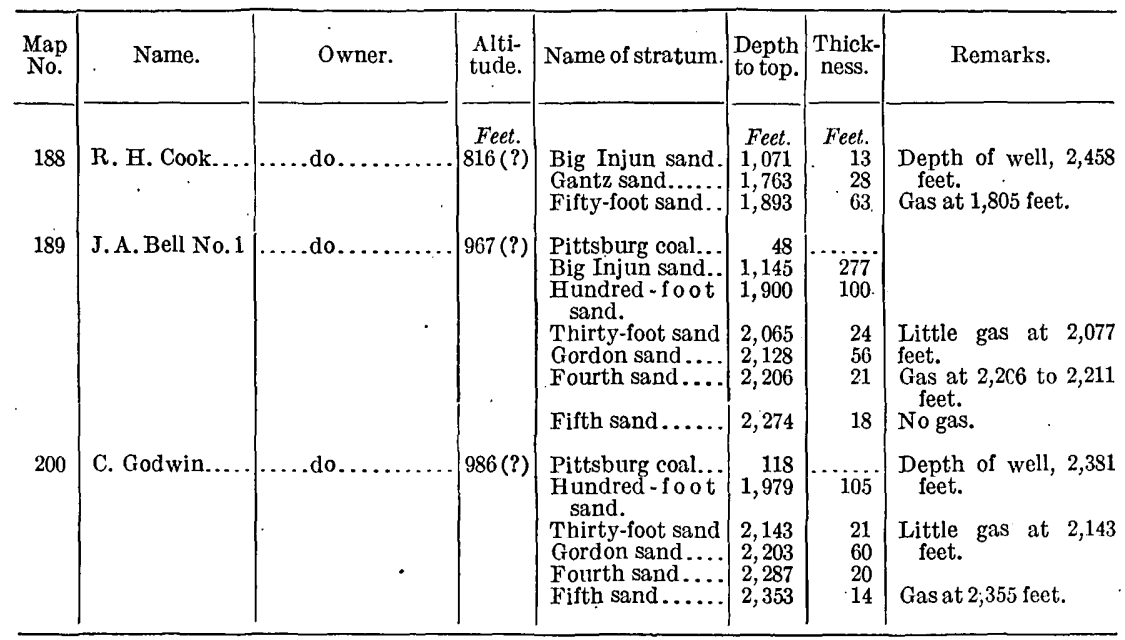

Clifton gas field.-This field is situated in the southeastern part of the township in the vicinity of Upper St. Clair. It has been developed by 20 or more wells, which found most of the gas in the Hundredfoot, Nineveh Thirty-foot, and Gordon Stray sands. One of these wells was drilled in $1887-88$ for oil and, proving to be a large gas well, was allowed to blow off in the air for a long time before the gas was utilized. Within the last few years a number of other wells have been put down in a cautious extension of the field, until it now appears to be fairly well developed. Some of the wells are still vigorous producers and will probably continue to furnish gas for many years.

Attention should be directed to the fact that in well No. 201 the Big lime (Greenbrier limestone member of Mauch Chunk formation) is noted as being 37 feet thick. With the possible exception of well No. 177, in the Woodville field, this is the most northern point at which the limestone has been positively identified. It increases in thickness southward, and in that direction is mentioned in hearly all detailed records of wells drilled to it. In well No. 201 gas occurs in the Fifty-foot and the Gordon Stray sands at depths of 5 and 19 feet, respectively, below the top of the sands. In well No. 202 the Fiftyfoot sand has two pay streaks, 9 and 36 feet below the top, and the pay streak in the Gordon Stray is 18 feet in the sand. In No. 204 gas occurs in the Fifty-foot sand 19 feet below the top, and in the Gordon Stray only 8 feet in the sand. In well No. 205, on the N. Fife farm, the Big lime is 23 feet thick. This well was found to contain no oil or gas, but some salt water was found in the Fifty-foot sand, about 
33 feet below the top. In this well an unusual thickness of sandstone occurs below the Nineveh Thirty-foot sand. The interval usually occupied by the Gordon Stray, the Gordon, the Fourth, and the Fifth sands seems to be occupied by thin layers of hard sandstone separated by a relatively small quantity of shale. In well No. 207, on the Espey heirs property, the Big lime is reported to be only 9 feet thick. Gas occurs in the Fifty-foot sand and what seems to be the Nineveh Thirty-foot sand in this well. In well No. 247, on the J. M. Boyce farm, the Gordon sand is recorded at a depth of 2,22.5 feet, or 2,145 feet below the Pittsburg coal. This well appears to be on or near the axis of the Nineveh syncline, which has a north-south trend in this vicinity.

Records of wells.-The following table gives the records of certain wells in the Clifton field:

Partial records of deep wells in the Clifton gas field, Upper St. Clair Township, Allegheny County, Pa.

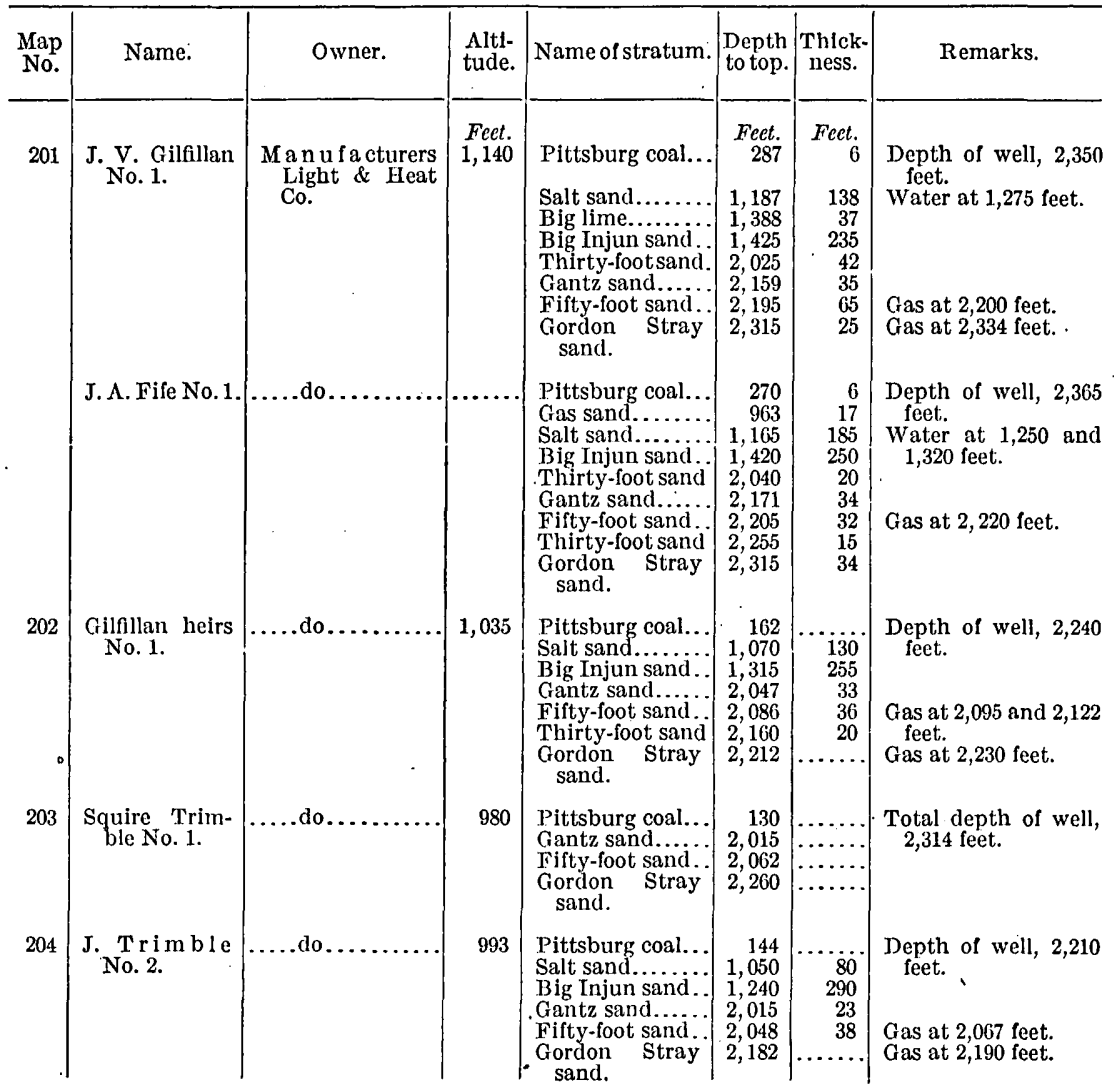

83448 ${ }^{\circ}-$ Bull. $456-11-6$ 
Partial records of deep wells in the Clifton gas field, Upper St. Clair Township, Allegheny County, Pa.-Continued.

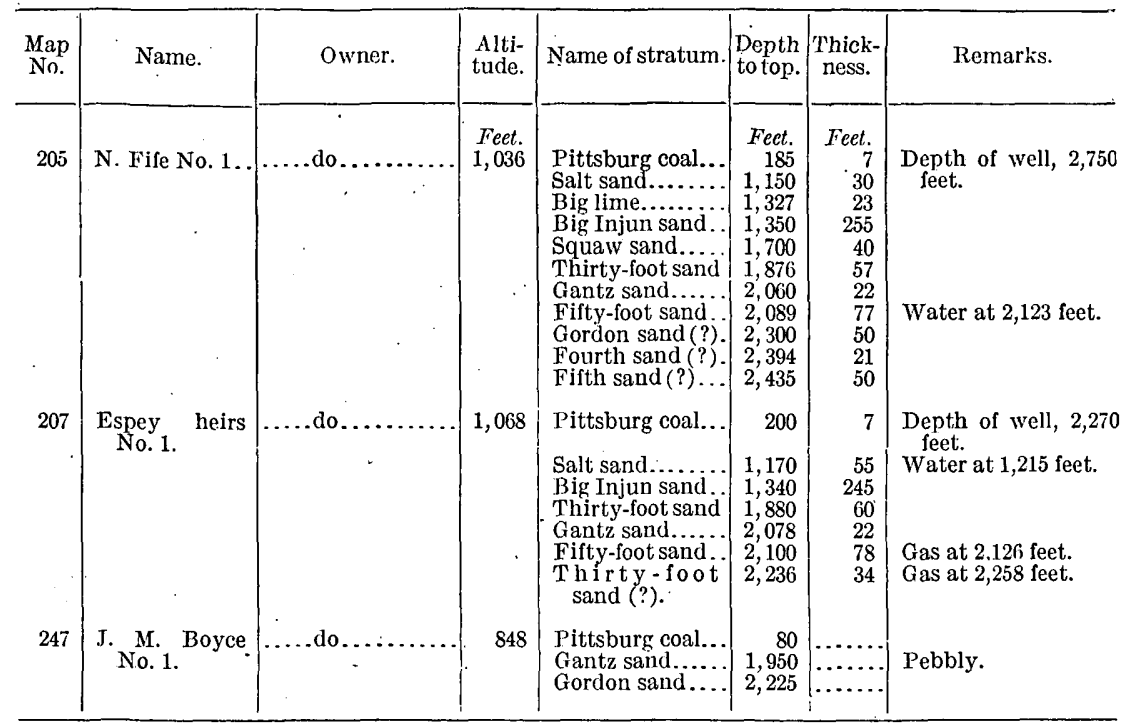

BETHEL AND SNOWDEN TOWNSHIPS, ALLEGHENY COUNTY.

All of Bethel and a considerable part of Snowden townships are embraced in the Carnegie quadrangle. In the former township no oil has yet been found in paying quantities, and, so far as the writer could learn by diligent inquiry in the field, only three deep wells have been drilled. Of these wells one on the L. Grazier farm, located about 1 mile northeast of Upper St. Clair, proved to be unproductive; the others, Nos. 208 and 209, in the vicinity of Library, are said to produce gas from the Fifth sand, but no data: relative to them, other than those shown in the records, were obtained: Records of wells in Bethel and Snowden townships have as a rule proved very unsatisfactory for close stratigraphic and structural work. This is due to the fact that the intervals between the various beds apparently increase from northwest to southeast across these townships, and that the Gordon Stray and the Gordon sands are either entirely absent or very poorly represented in this area. Evidence of this tendency of the Gordon and Gordon Stray sands to pinch out is shown in the records of the wells of the Clifton gas field, already listed; this change is also evident in the fields of Peters Township, Washington County, farther south. Coexistent with the thinning out of the Gordon and Gordon Stray sands there appears a marked increase in distance between the Fifth sand and the Pittsburg.coal which can not be explained satisfactorily by the change from a sandy to a shaly phase of sedimentation. Under ordinary conditions such a change should have a tendency to decrease rather than increase the interval between the beds above and below this horizon. After carefully examining all the available evidence relative to this point the writer considers it very probable that there 
is a slight increase in the distance between the Fifth sand and the Gordon sand, but that the greatest increase of the interval between the Fifth sand and the Pittsburg coal occurs above the Gordon and Gordon Stray sands. Therefore in these two townships the distance between the top of the Fifth sand and the top of the Gordon sand is calculated to be about 140 feet, and to remain fairly constant throughout the entire area, while the distance from the Gordon sand to the Pittsburg coal is considered to vary as indicated by the numbers on Plate V. This increase of interval seems to be largely due to the unconformity at the base of the Pottsville. It is evident that if all the records published in the table below had been carefully kept, and the depth, thickness, and character of each bed penetrated by the drill had been accurately noted, the variation of intervals between beds could be easily determined, with the result that a much more accurate structural map of the sands could have been made.

The records of wells Nos. 208 and 209 show little of stratigraphic or structural value. In the former, judging alone from distance between beds, the sand called the Fourth, which is said to furnish gas, is very probably the Fifth sand. In well No. 209 this sand is only 10 feet thick, and produces gas from a pay streak at the bottom. The Fifth is also the producing sand in No. 210, where it is reported to be open and pebbly. In well No. 211, on the William Cochran farm, the Salt sand supplies a large flow of gas. The Gantz and the Fifty-foot sands are here represented by "slate and shells," and the Nineveh Thirty-foot, Gordon Stray, Gordon, and Fourth sands are not noted. The Fifth sand is 18 feet thick, and furnishes gas from a pay streak 8 feet below the top. Well No. 212 on the William McConkey farm obtained salt water in the top of the Gas sand, with no gas; also a little water in either the Squaw or the Murrysville sand. The Gantz and the Fifty-foot sands are reported to be 100 feet thick, with gas 6 feet from the bottom. The Fourth and the Fifth sands are reported to be 30 and 14 feet thick, respectively, and both to be gas bearing. Well No. 213, on the Henry Miller farm, found salt water in the Salt and the Big Injun sands at 1,100 and 1,600 feet, respectively, and gas in what is supposed to be the Fifth sand at a depth of 2,560 feet. This well was finished in June, 1898. In well No. 214, on the McMasters farm, gas was found in what is designated by the driller as the Fifty-foot and the Fifth sands. This gas had a closed pressure of 80 pounds per square inch, which seems to be unusually low. In this well oil is reported from the Gordon sand at a depth of 2,300 feet and 2,215 feet below the Pittsburg coal. Since the normal distance between the Pittsburg coal and the Gordon sand throughout most of this quadrangle holds remarkably constant at about 2,100 feet, this correlation is open to question, though the distance is increased toward the east at a rate to make it about 2,160 feet in the vicinity 
of this well. It therefore seems more likely that the oil-bearing bed is really the Fourth sand, and that the gas-producing sand 200 feet below it is either the Elizabeth or the Sixth sand of Washington County. This sand also furnishes the gas from well No. 216 on the J. C. Wall farm. It is here reported to be only 5 feet thick, with gas at the bottom.

Records of wells.-The following table gives records of wells in Bethel and Snowden townships:

Partial records of deep wells in Bethel and Snowden townships, Allegheny County, Pa.

\begin{tabular}{|c|c|c|c|c|c|c|c|}
\hline $\begin{array}{l}\text { Map } \\
\text { No. }\end{array}$ & Name. & Owner. & $\begin{array}{l}\text { Alti- } \\
\text { tude. }\end{array}$ & Name of stratum. & $\begin{array}{l}\text { Depth } \\
\text { to top. }\end{array}$ & $\begin{array}{c}\text { Thick- } \\
\text { ness. }\end{array}$ & Remarks. \\
\hline 208 & Larimer No. 1.. & $\begin{array}{l}\text { Manufacturers } \\
\text { Light \& Heat } \\
\text { Co. }\end{array}$ & $\begin{array}{l}\text { Feet. } \\
1,002\end{array}$ & $\begin{array}{l}\text { Pittsburg coal... } \\
\text { Gantz sand..... } \\
\text { Fourth sand.... }\end{array}$ & $\begin{array}{r}\text { Fect. } \\
150 \\
2,106 \\
2,434\end{array}$ & $\mid \begin{array}{l}\text { Feet. } \\
\cdots \cdots\end{array}$ & $\begin{array}{l}\text { Depth of well, } 2,468 \\
\text { feet. } \\
\text { Water. } \\
\text { Fifth (?) sand. }\end{array}$ \\
\hline 209 & $\begin{array}{l}\text { R. A. Long } \\
\text { No. } 1 .\end{array}$ & $\ldots$............... & 1,000 & $\begin{array}{l}\text { Pittsburg coal... } \\
\text { Fifth sand...... }\end{array}$ & $\begin{array}{r}140 \\
2,440\end{array}$ & $\cdots$ & $\begin{array}{l}\text { Depth of well, } 2,470 \\
\text { feet. }\end{array}$ \\
\hline 210 & $\begin{array}{l}\text { B } 1 \mathrm{um} \text { enstein } \\
\text { No. } 1 .\end{array}$ & $\ldots .$. do.......... & 1,079 & $\begin{array}{l}\text { Pittsburg coal... } \\
\text { Gantz sand...... } \\
\text { Fifty-foot sand.. } \\
\text { Stray sand...... } \\
\text { Fifth sand..... }\end{array}$ & $\begin{array}{r}215 \\
2,114 \\
2,135 \\
2,264 \\
2,498\end{array}$ & $\begin{array}{c}\ddot{45} \\
20\end{array}$ & $\begin{array}{l}\text { Depth of well, } 2,623 \\
\text { feet. } \\
\text { Water at } 1,930 \text { feet, } \\
\text { salt. }\end{array}$ \\
\hline 211 & $\begin{array}{l}\text { Wm. Cochran } \\
\text { No. } 1 .\end{array}$ & $\ldots$. do........... & 1,170 & $\begin{array}{l}\text { Pittsburg coal... } \\
\text { Salt sand........ } \\
\text { Big Injun sand.. } \\
\text { Fifty-foot sand.. } \\
\text { Fifth sand...... }\end{array}$ & $\begin{array}{r}290 \\
1,215 \\
1,470 \\
2,310 \\
2,590\end{array}$ & $\begin{array}{r}40 \\
255 \\
90 \\
18\end{array}$ & $\begin{array}{l}\text { Depth of well, } 2,620 \\
\text { feet. } \\
\text { Heavy flow of gas. } \\
\text { Slate and shells. } \\
\text { Gas at } 2,598 \text { feet. }\end{array}$ \\
\hline 212 & $\begin{array}{l}\text { W. McConkey } \\
\text { No. } 1 .\end{array}$ & .... do.... & 1,095 & $\begin{array}{l}\text { Pittsburg coal... } \\
\text { Salt sand....... } \\
\text { Injun sand..... }\end{array}$ & $\begin{array}{r}214 \\
1,133 \\
1,385\end{array}$ & $\begin{array}{l}137 \\
265\end{array}$ & Water on top; no gas. \\
\hline & & , & - & $\begin{array}{l}\text { Fifty-foot sand. } \\
\text { Fourth sand.... } \\
\text { Fifth sand..... }\end{array}$ & $\begin{array}{l}2,140 \\
2,440 \\
2,489\end{array}$ & $\begin{array}{l}30 \\
14\end{array}$ & $\begin{array}{l}\text { Hundred-foot s a n d } \\
\text { (?); gas at } 2,234 \\
\text { feet. } \\
\text { Gas in Fourth. } \\
\text { Gas. }\end{array}$ \\
\hline 213 & H. Miller..... & Jefferson Oil Co.. & 1,142 & $\begin{array}{l}\text { Pittsburg coal... } \\
\text { Big Injun sand.. } \\
\text { Fifth sand...... }\end{array}$ & 245 & & $\begin{array}{l}\text { Depth of well, } 2,825 \\
\text { feet. } \\
\text { Salt water a b c u t } \\
1,600 \text { feet. } \\
\text { Gas at } 2,560 \text { feet. }\end{array}$ \\
\hline 214 & McMasters..... & .... do.......... & 1,007 & $\begin{array}{l}\text { Pittsburg coal... } \\
\text { Fifty-foot sand.. } \\
\text { Gordon sand.... } \\
\text { Fifth sand (?)... }\end{array}$ & $\begin{array}{r}85 \\
2,067 \\
2,300 \\
2,500\end{array}$ & & $\begin{array}{l}\text { Depth of well, } 2,510 \\
\text { feet. } \\
\text { Gas. } \\
\text { Oil. } \\
\text { Gas. Sixth sand (?). }\end{array}$ \\
\hline 216 & J. C. Wall..... & Philadelphia Co.. & 1,167 & $\begin{array}{l}\text { Big Injun sand.. } \\
\text { Gantz sand..... } \\
\text { Fifty-foot sand.. } \\
\text { Fifth sand...... } \\
\text { Sixth sand...... }\end{array}$ & $\begin{array}{l}1,325 \\
2,041 \\
2,102 \\
2,461 \\
2,580\end{array}$ & $\begin{array}{r}300 \\
20 \\
49 \\
30 \\
5\end{array}$ & $\begin{array}{l}\text { Depth of well, } 2,702 \\
\text { feet. } \\
\text { Gas at } 2,585 \text { feet. }\end{array}$ \\
\hline
\end{tabular}

UNION TOWNSHIP, WASHINGTON COUNTY.

A small portion of Union Township is included in the southeast corner of Carnegie quadrangle. In this township are several gas wells which are generally included in the Finleyville oil and gas field, most of which lies in the Amity quadrangle.

Finleyville oil and gas field.-Within the Carnegie quadrangle this field has produced no oil unless from a few wells now abandoned in 
the village of Finleyville on the southern border. In well No. 217 the gas comes from the so-called Gas sand, which is in reality the Mahoning sandstone member or Dunkard sand of drillers farther south in Washington and Greene counties. This sand is here only 660 feet below the Pittsburg coal. The record of well No. 218 is very incomplete, and nothing of value regarding it is known other than that the Hundred-foot sand furnishes the gas. Well No. 219 is located on the Frye heirs property, less than half a mile off the quadrangle south of Finleyville. This well is said to have been a freak oil well in the Fifty-foot sand. From information gathered from citizens of Finleyville it appears that this well when drilled in began flowing a very heavy ciark oil at the rate of more than 100 barrels per day. Other wells drilled in short distances on all sides of this well, with the single exception of one about 100 feet away, are said to have been unproductive. This oil pool evidently covers less than 2 acres. Both of the successful wells are still producing a few barrels of oil per week. In the village of Finleyville a number of wells have found gas in the Fifty-foot sand. Of these, the C. Tritchman No. 1 well (No. 220) found the Gantz and the Fifty-foot sands to have a thickness of 33 and 42 feet, respectively, with a 10 -foot break between. The gas pay streak occurs in the Fifty-foot sand 29 feet from the top.

Records of wells.-The following table gives records of certain wells in Union Township:

Partial records of deep wells in Union Township, Washington County, Pa.

\begin{tabular}{|c|c|c|c|c|c|c|c|}
\hline $\begin{array}{l}\text { Map } \\
\text { No. }\end{array}$ & Name. & Owner. & $\begin{array}{l}\text { Alti- } \\
\text { tude. }\end{array}$ & $\begin{array}{c}\text { Name of stratum. } \\
\text { :!: }\end{array}$ & $\begin{array}{l}\text { Depth } \\
\text { to top. }\end{array}$ & $\begin{array}{l}\text { Thick- } \\
\text { ness. }\end{array}$ & Remarks. \\
\hline 217 & $\begin{array}{l}\text { S. F. Boyer } \\
\text { No. } 1 .\end{array}$ & Lisle \& McClay.. & $\begin{array}{l}\text { Feet. } \\
1,143\end{array}$ & $\begin{array}{l}\text { Pittsburg coal... } \\
\text { Gas sand (Dunk- } \\
\text { ard). }\end{array}$ & $\begin{array}{r}\text { Feet. } \\
90 \\
750\end{array}$ & $\begin{array}{l}\text { Fect. } \\
\text {...... }\end{array}$ & $\begin{array}{l}\text { Depth of well, } 805 \\
\text { feet. } \\
\text { Gas at } 780-303 \text { feet. }\end{array}$ \\
\hline 218 & $\begin{array}{l}\text { H. Smith No. } \\
\text { 1. }\end{array}$ & $\begin{array}{l}\text { Monongahela Gas } \\
\text { Co. }\end{array}$ & 971 & $\begin{array}{l}\text { Gantz sand..... } \\
\text { Fifty-foot sand.. }\end{array}$ & $\begin{array}{l}1,900 \\
1,950\end{array}$ & & $\begin{array}{l}\text { Depth of well, } 2,004 \\
\text { feet. }\end{array}$ \\
\hline 219 & Frye heirs No. & & 966 & Gantz sand..... & 1,920 & 90 & \\
\hline 220 & $\begin{array}{l}\text { C. Tritchman } \\
\text { No. } 1 .\end{array}$ & Claartiers Oil Co.. & 950 & Fifty-foot sand... & $\begin{array}{l}1,880 \\
1,923\end{array}$ & $\begin{array}{l}33 \\
42\end{array}$ & $\begin{array}{l}\text { No oil or gas. } \\
\text { Gas at } 1,952 \text { feet. }\end{array}$ \\
\hline
\end{tabular}

PETERS AND NORTH STRABANE TOWNSHIPS, WASHINGTON COUNTY.

These townships embrace that part of the quadrangle which lies in Washington County west of Union Townsbip and southeast of Chartiers Creek. The Nineveh syncline crosses the western part of Peters Township in a north-south direction. The Waynesburg anticline crosses the southeastern portion of the quadrangle through Peters, Union, and Snowden, with a northeast-southwest trend. Along the axis and flanks of the latter fold a number of gas wells have been found in the southeastern part of Peters Township. In a well (No. 
221) on the David Reese property gas was found in the Dunkard sand, mentioned above as being equivalent to the so-called Gas sand of well No. 217. Gas alsc occurs in the Salt, the Big Injun, and the Gantz sands, wilh a small quantity of oil in what is described as "slate and shells" at a horizon somewhat below that of the Fifth sand. Well No. 223 on the David Higbie farm found gas in the Fifty-foot sand, having a minute pressure of 38 pounds. Well No. 224 on the Townsend farm got gas from a 2-foot pay in the Fifth sand at a depth of 2,550 feet.

In this portion of Peters Township many wells showed more or less salt. water in some portion of the Gantz sand or of the Fifty-foot sand. The volume of gas in all of them was relatively small.

McMurry oil and gas field.-The McMurry field includes an oil and gas producing belt from near the Allegheny County line southwest across the center of Peters Township to Little Chartiers Creek. Oil in this field comes almost entirely from the Fifty-foot sand, which also furnishes more or less salt water with the oil. The most persistent gas pool is in the Fifth sand, but pools of less size are also found in the Gordon, the Gordon Stray, and the Nineveh Thirty-foot: sands. This field was first developed as an oil pool in the Fifty-foot sand, but, although some of the wells started off with a fair production, many of them declined rapidly, and were down to a few barrels per day within two to four years. These were then drilled deeper and developed considerable gas in the Fifth sand.

The sands of this field appear to contain considerably more than an average amount of salt water. A number of operators report that in many places the Salt and the Big Injun sands when first tapped by the drill flowed salt water in large quantities, the water from the latter sand being accompanied by considerable gas. The Gantz sand is said to contain some salt water, but most of the water of the Hundred-foot comes from the lower member or the Fifty-foot sand. This water is said to have a head of 300 to 400 feet. Salt water seems to occur less often, in smaller quantities and with a lower head, in the Gordon and the Fifth sands. Data relative to the water conditions in these sands are scant, and their reliability is not above question, but it appears to be generally recognized as a fact that both these sands do carry more or less salt water, and that in many wells which produce gas from the Fifth sand a small amount of salt water eventually makes its appearance. There seems to be no way of determining definitely whether this water is indigenous to the Fifth sand or comes from some higher bed.

In well No. 227 on the Lushen farm the Fifty-foot sand has an oil pay streak extending from 2 to 12 feet below the top of the sand. The Fifth sand furnishes gas in this well. In well No. 228 on the Albert E. Fife farm a show of oil was found in the Fifty-foot sand at 
a depth of 2,208 feet, with a show of gas in the Gordon sand at 2,445 feet. The Sixth sand was also noted in this well, the top of which is at a depth of 2,676 feet, or 136 feet below the top of the Fifth. The normal distance between the tops of the Gordon and the Fifth sands throughout a considerable part of this quadrangle farther to the southeast is from about 120 to 140 feet; in well No. 228 this distance is reduced to 95 feet, and on the south, in well No. 229, on the H. B. McMurry farm, this distance is exactly 100 feet. In the last-mentioned well the Gordon Stray is separated from the Gordon by 55 feet of shale, which is the greatest distance between these beds known in the quadrangle. The Big lime is here (No. 229) 40 feet thick, and directly overlies the Big Injun sand. Oil and water occur in the 6 feet of the Fifty-foot sand. In well No. 230, on the Mitchell Douglas farm, gas and salt water occur in the Salt sand, and gas also in the Fifth and in what is called the Thirty-foot sand, which is here separated from the top of the Gordon below by 65 feet of shale. This sand seems to be the same as that designated in well No. 229 as the Gordon Stray. Sufficient data are not available to make a definite correlation of these beds. The Gordon Stray and the Gordon sands in well No. 231 seem to be united into a sandstone 100 feet thick which carries gas 70 feet below the top. In well No. 233 the Fifty-foot sand is reported to be dry, with gas in the Fifth sand 5 feet below the top. The Big Injun sand showed a little oil in well No. 234, with some gas in the Fifty-foot, and some oil in the Gordon at a depth of 2,415 feet, the top of the pay streak being 20 feet in the sand.

South of this well no wells are known to have been drilled nearer than those of the field in the vicinity of well No. 236, which was a gas well in the Salt sand and an oil and water well in the Fifty-foot sand. These are the productive sands in wells Nos. 237, 238, 239, 240,241 , and 242; the last-named well also furnishes gas from the Gantz sand. It will be observed that a sand called Maxon sand has been noted in a number of wells in this field: This sand overlies the Big lime in some wells, but in well No. 244 the sand is overlain by 12 feet of limestone, which is locally known as Little lime. In well No. 243 the sand known as the Maxon sand is water bearing. The Gordon and the Fifth sands also produce gas in well No. 244, and the Fifty-foot sand some oil. West of well No. 244 the sands appear to dip sharply toward the trough of the Nineveh syncline, and the productive area abruptly ceases.

Only a few measurements of closed pressures of gas wells in this field were obtained. These vary from about 125 pounds in the Salt sand to approximately 900 pounds in the Fifth. No facts are at hand to show whether the closed pressure of gas in the different sands increases uniformly with an increase in depth or not. In the fields 
of the quadrangle this is generally true, though each sand shows great local variations in closed pressures from pool to pool.

West of the McMurry field few deep wells have been drilled in the townships outside of the Canonsburg field, which has been already described under Chartiers and Cecil townships. One or two of these scattered holes have found small flows of gas in one or more sands, but no oil in paying quantities. In one of these wells (No. 245) on the John McDowell farm, gas was found in the Gantz, the Fifty-foot, and the Gordon Stray sands', with also a show of oil in the Fifty-foot. This well is located near the axis of the Nineveh syncline, but no mention is made of water in any of the sands, and the fact that the record of this well shows that $6 \frac{1}{4}$-inch casing was put only through the Salt sand and the further fact that the lower sands carry gas indicate that it is remarkably free from salt water. It is to be regretted that the closed pressure of the gas in each of the producing sands in this well was not recorded. The maximum pressure is said to be about 400 pounds per square inch. The records of wells

- Nos. 246 and 248 are so incomplete as to be of little value.

Records of wells.-The following table shows records of wells in Peters and North Strabane townships:

Partial records of deep wells in Peters and North Strabane townships, Washington County, $\mathrm{Pa}$.

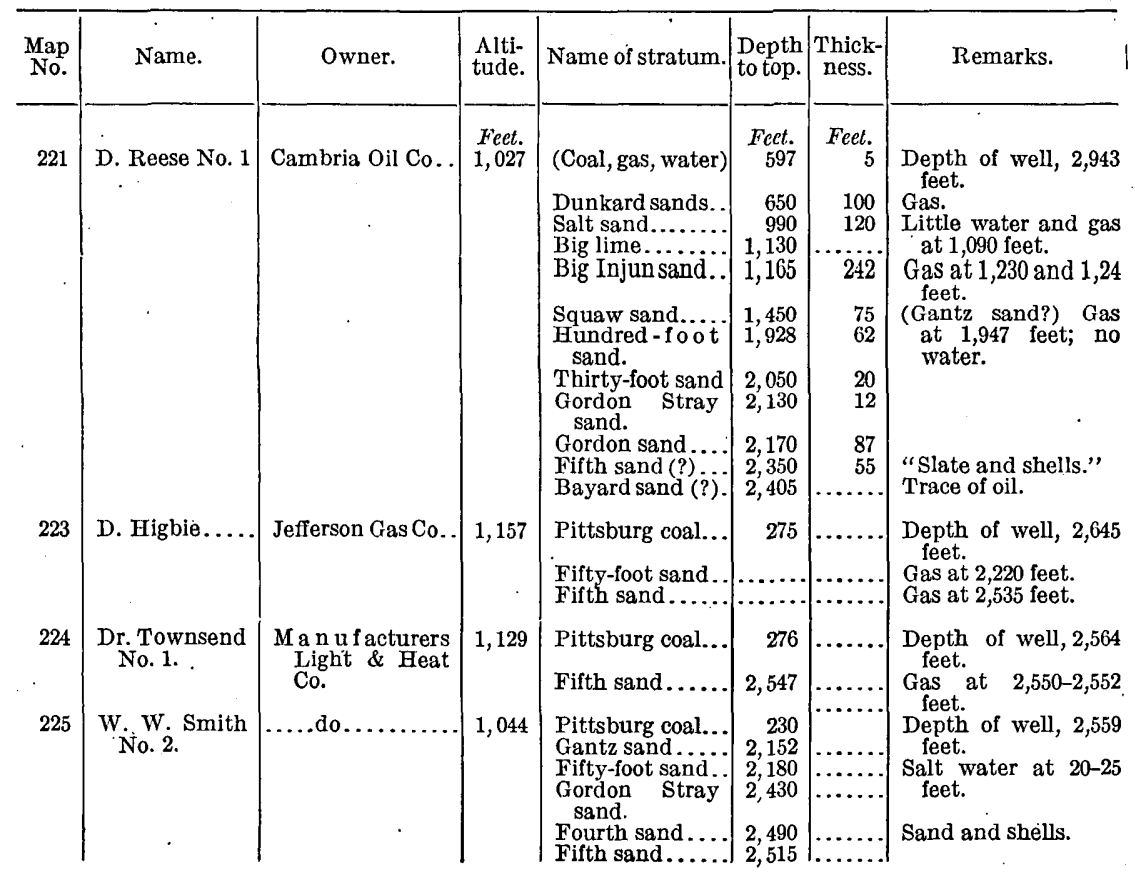


Fartial records of deep wells in Peters and North Strabane lownships, Washington County, $P a$.-Continued.

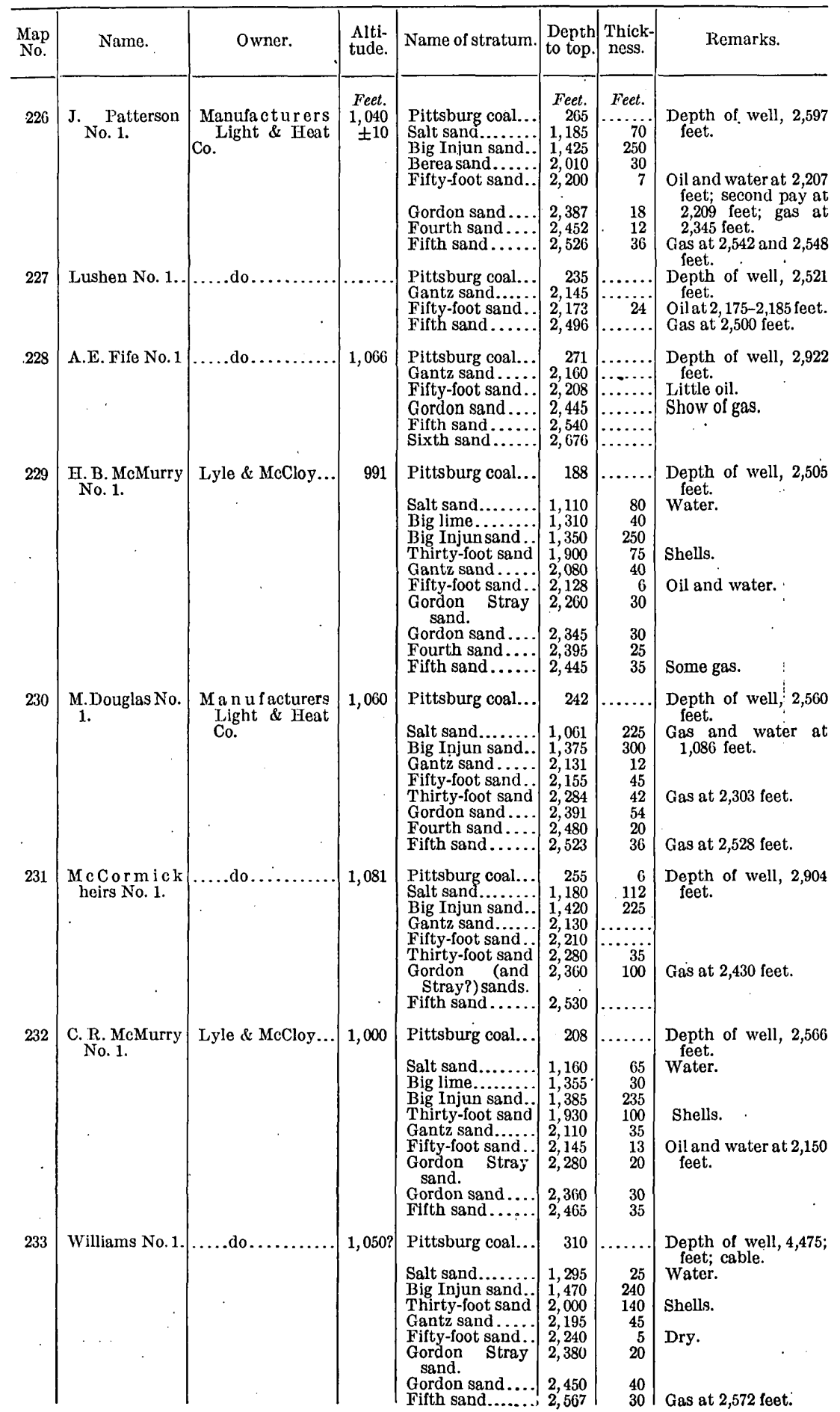


Partial records'of deep wells in Peters and North Strabane townships, Washington County, Pa.-Continued.

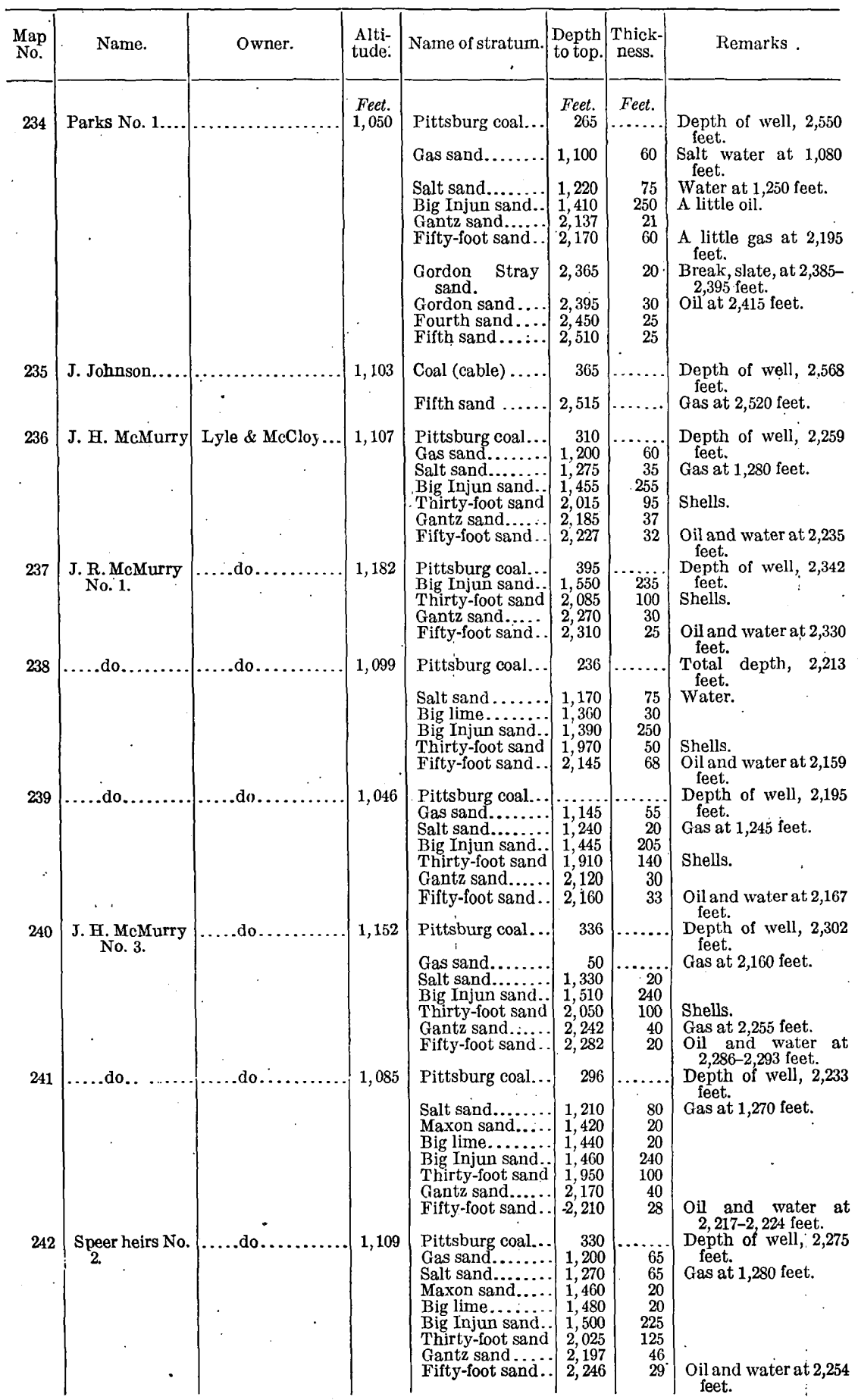


Partial records of deep wells in Peters and North Strabane townships, Washington County, Pa.-Continued.

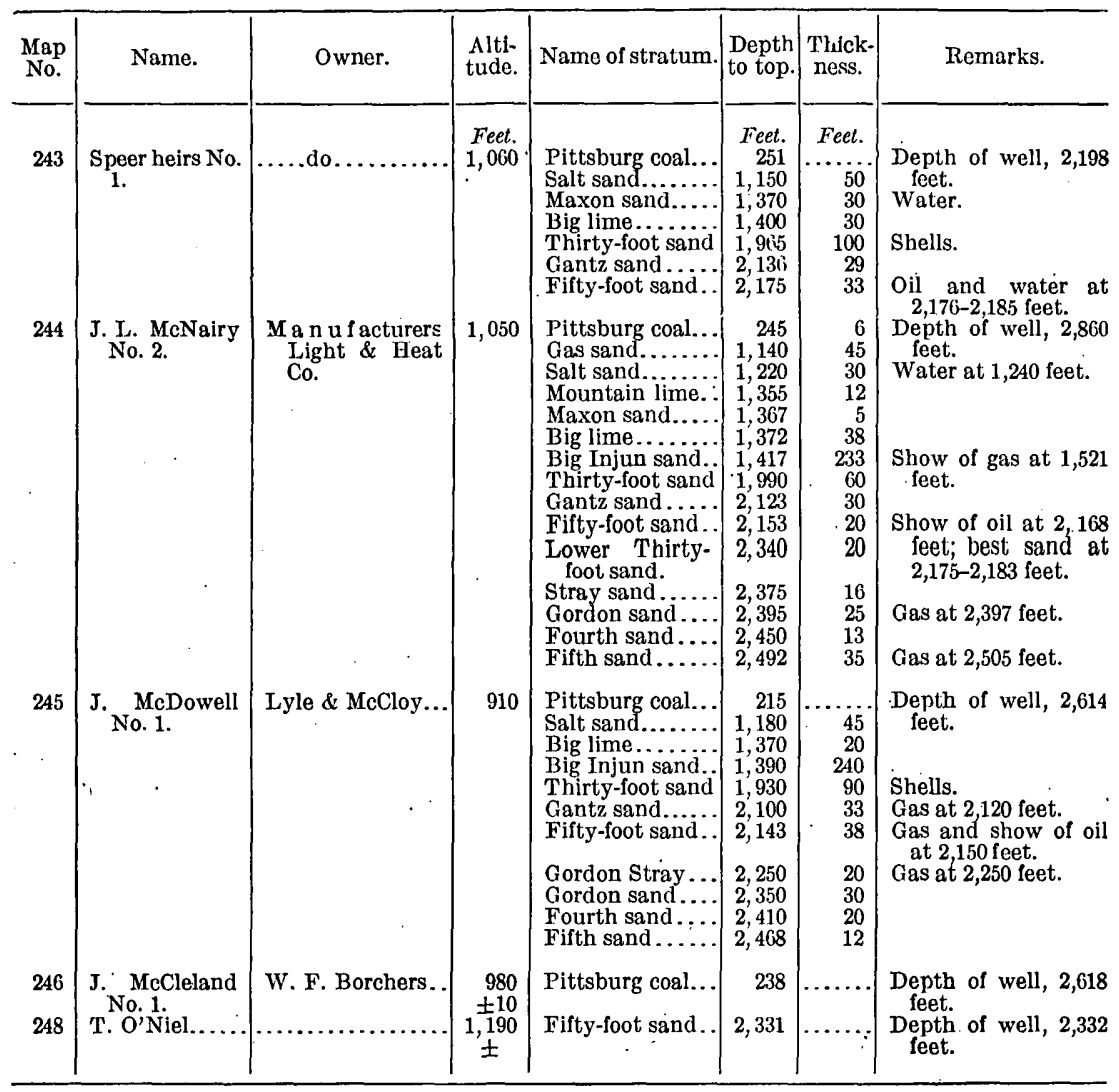

\section{GENERAL STRUCTURAL POSITION OF OIL AND GAS POOLS IN EACH PRODUCING SAND.}

If the positions taken by accumulations of oil and gas are to any extent due to the folds in the oil sands, the pools in each sand, over greater or less areas, should show similar structural relations, the amount of the accumulated oil being coordinated with the structure. Conversely, the lack of similarity in the structural arrangement of pools should indicate that other geologic factors were involved in the process of accumulation.

The structural position of the oil and gas pools in each sand are shown on the accompanying maps, and only the analogy in position of some of the pools need be pointed out.

Fifth sand.-The largest accumulation in this sand, the McDonald pool, occupies a broad structural terrace extending northeastsouthwest, from which the rocks. dip relatively steeply southeast to 
the axis of the Nineveh syncline. This terrace is broken by many small secondary folds of local extent only, and it is limited on the northwest by a somewhat more rapid and uniform rise of the rocks in that direction. The dip along the major axis of this pool is about 140 feet in 11 miles, or approximately 14 feet per mile. From northwest to southeast across the pool the dip varies at different points from about 20 to 65 feet per mile.

Northward the oil pools in this sand in the Moon Run field occupy successively higher positions along the same structural terrace, which gradually assumes the form of a low arch pitching south.

Still farther north along this anticline the oil in this sand gives way to accumulations of gas in the vicinity of the Ohio River. In the western part of the Moon Run field, south of Beacon, the gas pool in the Fifth sand is structurally slightly higher than the oil in the McCurdy pool, to which it seems closely connected, but lower than the oil pool lying east on the crest of the anticline.

The Fifth sand pool of the Canonsburg field occupies a small sloping terrace very similar to that occupied by the southern part - of the McDonald pool, but about 100 feet lower down the slope and on the southern side of the Cross Creek syncline. Southwest of this pool, up the slope and on the crest of the Westland dome, occur the corresponding gas pools.

Northeast of the Canonsburg pool; along the strike of the oil sand, on the north side of the Cross Creek syncline, occur the small|gas pools of this sand in the Lickskillet, Hopper, Cuddy, and Bridgeville fields, which appear not to be intimately associated with accumulations of oil in this sand. In the McMurry field the gas accumulations that have been so far discovered lie in a belt parallel to the strike of the rocks, the lower edge being at a slightly lower level structurally than the last-named pools and about 75 feet below the Canonsburg oil pool. This fact shows greater structural significance when it is remembered that the Fifth sand rises southeastward from this belt to the crest of the Amity anticline, and that, so far as known, this sand is continuous over the area. The general structuíal features of the Fifth sand pools in this quadrangle are that the areas of accumulation are highest at the northwest and become isuccessively lower toward the southeast, regardless of the size and height of the anticlines in the bed, and that each separate accumufation tends more or less toward an arrangement by which its major axis lies parallel to the strike of the rocks.

Fourth sand.-The structural map of the oil and gas pools shows that the Fourth sand gas pool in the Aten field, near the northwest corner of the quadrangle, lies squarely across the contour lines and therefore directly up the slope of the sand, covering a vertical range of about 90 feet between the 1,040-foot and the 1,130-foot contours. 
East of this pool on the flat, southward-pitching crest of the Wildwood anticline a number of small gas pools have been noted between the 1,000-foot and the 1,100-foot contours. The Fourth sand oil pool in the central part of the Moon Run field occupies the crest of a secondary anticline between the 1,080-foot and the 1,100-foot contours. On the next anticline northeast a small gas pool has been developed by two wells on the property of the Pressed Steel Car Co., at McKees Rocks, which is on the 1,030-foot contour.

South of this productive belt the. Fourth sand is barren of oil or gas, except one or two very small accumulations along the Fifth sand terrace in the McDonald field, the next important accumulation being the great Venice-Hopper oil pool. This accumulation lies roughly between the 800 -foot and the 900 -foot contours, and its major axis extends along the strike of the rocks at an average elevation of 850 feet. This area forms a productive belt between the 800 -foot and the 900 -foot contours along the relatively steep western limb of the Nineveh syncline. It will be seen that the few small oil and gas pools in this sand in the Canonsburg district occur along this belt. Two gas wells in the Fourth sand about 1 mile east of Cecil, and another in the Bridgeville field, 3 miles away, are practically on the 760-foot contour, and, so far as they go, show a tendency toward another productive belt at a lower level in the sand than the VeniceHopper field, though the two great belts mentioned above cover practically all of the known oil and gas pools in this quadrangle. Here, again, is seen the tendency of pools to accumulate in successively lower belts from northeast to southwest.

Gordon sand.-The oil and gas pools in the Gordon sand do not show as clearly defined belts of accumulation as those in the sands already described. The Moon pool, at the northwest corner of the Carnegie quadrangle, lies between the 1,060-foot and the 1,110-foot contours; the Aten gas field is between the 1,070-foot and the 1,080-foot contours; and the Coraopolis oil pool, farther northeast, just off the northern border, lies mostly between the 1,060-foot and the 1,110-foot contours, the most northern extension reaching up to the 1,120-foot level.

In the Ewing Mills pool the gas is at an elevation of 1,040 to 1,050 feet, while the gas pools in the vicinity of Neville Island range from the 1,100-foot to the 1,150-foot contours. This producing belt continues to rise higher in the sand farther northeast beyond the limits of the Carnegie quadrangle. South of Beech Cliff mines, in North Fayette Township, are three small gas wells in the Gordon sand, which are between the 1,000-foot and the 1,030-foot contours. This is also the height of a small pool in the western part of the McCurdy field. Continuing eastward the 1,000-foot contour is found to mark somewhat closely the southern border of the Gordon 
oil pool in the Moon Run field, though this pool extends upward along the pitching crest of the anticline for about 70 feet and in the Chartiers oil field ranges from the 990 -foot to the 1,060-foot contours.

The great Gordon sand pool in the McDonald field has the same general outline as the Fifth sand pool in that field, which has been described. The upper edge of this pool is probably at about the 990 -foot contour at the northern end, from which it drops about 100 feet southeast in the Carnegie quadrangle. At the northern end the lower line of the oil-producing area in this sand is at an altitude of about 940 feet, from which point it crosses the contours diagonally down slope to the southern edge, the 820 -foot contour being about the lowest reached. Down the dip of the sand from this pool occurs the gas pool in the Hopper field between the 840-foot and the 860-foot contours.

In the Canonşburg district the principal oil pools are between 800 and 840 feet in elevation, with the eastern extension of the great Hickory gas field at about 890 to 970 feet. Several very small pools of oil have been found in this field at various levels along the western limb of the Nineveh syncline, where the Gordon sand has the greatest dip within the quadrangle.

East of the Nineveh syncline a small pool of gas occurs in the Bridgeville field at an elevation of about 770 feet, which is at the same level as the upper edge of the gas pool in the Clifton field, 3 miles farther southeast. In the McMurry field three of the six small pools discovered lie on the 650-foot contour-one on the 670-foot contour, the remaining two at elevations of 620 and 510 feet, respectively.

Nineveh Thirty-foot sand.-The pool in the Bellevue field at the northern edge of the quadrangle is structurally the highest in the Nineveh Thirty-foot sand in the Carnegie quadrangle. It occupies the southward-pitching trough of the Nineveh syncline between the 1,090. foot and the 1,120-foot contours. South of this pool in the same trough gas occurs in a well of the Pittsburg Forge \& Iron Co. in Allegheny on the 1,060-foot contour. The oil and gas pools in the Ewing Mills field occur about 20 feet farther down the dip. The Imperial pool, which is the largest in this sand in the Carnegie quadrangle, lies along a belt of comparatively steep dip, just north of the Mount Nebo syncline, with the major axis of the pool parallel to the structural contours. The upper edge of this pool is on or near the 1,020-foot contour, the lower side being at an elevation of about 970 feet. On the opposite side of the Wildwood anticline from the Imperial pool, oil and gas pools in the Nineveh Thirty-foot sand occur south of Beacon on the 1,020-foot contour. Oil has also been found in the McCurdy field in this sand in a small syncline in the eastern side of the Wildwood anticline at an elevation of 960 to 980 feet. The Nineveh Thirty-foot sand pool in the Woodville field lies squarely in the bottom 
of a small basin in the trough of the Nineveh syncline at an elevation of 680 to 700 feet. The gas pool in this sand at Bridgeville can not be clearly outlined, but it appears to occupy the pitching end of a secondary anticline at an elevation of about 740 to 780 feet. With this possible exception, the Nineveh Thirty-foot pools show invariably a tendency toward accumulation in synclines, and, so far as may be observed from scattered pools, a fairly close structural arrangement for each belt of pools.

Hundred-foot sand.-The Aten and the Imperial pools in the Hundred-foot sand appear to belong. to separate productive belts, the former being between the 1,040-foot and 1,080-foot contours and the latter at an elevation of 990 to 1,000 feet, with a dry area between them. Traced eastward these two productive belts appear to merge in the western part of the Moon Run field, where the larger pools lie between the 1,020-foot and 1,100-foot contours, along the pitching axis of a small anticline. Similar anticlines farther east also carry pools at successively high points in the sand.

Another belt of productive territory in the Hundred-foot sand is marked by a number of small gas and oil pools in the Venice and Canonsburg fields between the 800-foot and the 840-foot contours. This may be traced northeast through the Mawhinney, Cecil, Hopper, Cuddy, and Lickskillet oil fields, which collectively occupy a belt between the 690 -foot and the 840 -foot contours. This belt may be continued across the Nineveh syncline in the vicinity of Woodville and thence southeast through the Clifton gas pool, which lies between the 720-foot and the 780-foot contours. Farther southeast from this pool two small gas areas occur near the eastern border of the quadrangle, one on the 720-foot contour and the other on the 760 -foot contour. From this point southwest along the strike of the rocks the producing belt in the Hundred-foot sand in the McMurry field occurs between the 650-foot and the 670-foot contours. This is one of the most striking structural alignments shown by pools in the quadrangle, and is indicative of what has been found to occur in this sand in the Sewickley quadrangle, which joins the Carnegie to the north. On the Amity anticline, at the southern border of the quadrangle, a single well obtained a small amount of gas from the Hundred-foot sand between the 850-foot and 860-foot contours, and in the Finleyville field both gas and oil occur at elevations ranging from about 800 to 830 feet. This productive belt has not been traced farther northeast, but it presumably coincides with the Castle Shannon gas pool, which lies between the 830 -foot and the 860 -foot contours.

In conclusion, this brief discussion of the structural position of the pools indicates: (1) That the individual study of pools by sands is of far greater value than the general grouping of fields along folds without regard to the producing sands; (2) that areas found to produce 
from two or more sands are in many cases especially favored structurally, but that the fact that productive belts in one sand in most cases do not conform to productive belts in another sand shows that other factors, probably even more important than structure, affect the position of oil and gas pools; (3) that the structural analogy of pools in a given sand relates not so much to definite structural features, as anticlines or synclines, as it does to the height of the pools above some horizontal plane; (4) that each of the oil or gas bearing sands has a series of productive belts at structurally different heights, and that these belts occupy successively lower elevations from northwest to southeast across the Carnegie quadrangle regardless of the heights or depths of the various folds with which they are associated; (5) that there is a general inclination of each productive belt to ascend the structure toward the northeast and to descend it toward the southwest; and (6) that future drilling to be most effective in opening new pools in this quadrangle should be conducted along the structural lines of productive belts and not in the barren or less productive areas between. 


\section{INDEX.}

A. Page.

Allegheny formation, position and geologic relations of ....................

Amity anticline, structural features of ....... $\Lambda$ ten oil and gas fieid, wells of, distribution and character of.

B.

Baldwin Township, oil and gas fields of, distribution and character of ...... 74-78

wells in, records of. $78-78$
78

Bellevue oil and gas field, wells of, distribution and character of.......... 72

wells of, records of................. 73-74

Benwood limestone, character and thickness of .........................

Bethel Township, oil and gas fields of, distribution and character of ......... 82-84

wells in, records of.

Big Injun sand, character and distribution of , 16-17

Bowlder (?) sand, character and position of.

Bridgeville gas field, wells of, distribution and character of ................. 79

wells of, records of. $79-80$

Butler Thirty-foot sand, character and distribution of.

$15-16$

C.

Canonsburg oil field, Cecil Township, oil and gas pools of, distribution and character of................... 35-38

oil and gas pools of, wells of, records of . . 36-37

Carboniferous system, exposed rocks of, character, distribution, and subdivisions of . . . . . . . . . . . . .

unexposed rocks of, character, distribution, and subdivisions of........ 15-25

Carnegie quadrangle, location of ........... $7-8$

location and area of, map showing...... 7

maps of ................. 7,30 , in pocket.

wells in, sections of, plates showing..... 10

Castle Shannon gas pool, wells of, distribution and character of .............. 77-78

wells of, records of.................. 78

Catskill (?) formation, character, distribution, and subdivisions of ............ 13-15

Cecil oil pool, present status of............. 39

Cecil Township, oil and gas pools of, distribution and character of .......... 35-43

wells in, records of..... 20,36-37, 38, 40-41, 42-43

Chartiers oil and gas field, wells of, distribution and character of........... 73

wells of, records of ................... $73-74$

Chartiers Township, oil and gas pools of, distribution and character of....... 33-35

wells in, records of 34
Clifton gas field, wells of, distribution and character of .................. 80-82 wells of, records of ................... 81-82

Collier Township, oil and gas fields of, distribution and character of.......... 74-78

wells in, records of.................. 76

Conemaugh formation, exposed rocks of, character and subdivisions of .........

unexposed rocks of, position and geologic relations of ..................... 19

i Contours, structural, accuracy of ......... 29-31

Cross Creek syncline, structural features of... 32

Cuddy oil and gas field, wells of, distribution and character of .............. 51-54

wells of , records of................... 52-53

D.

Devonian system, rocks of, character and distribution of..................11-13

rocks of, well section illustrating........ 11-12

Devonian (?) system, character, distribution, and subdivisions of . ........... 13-15

Drainage, features of .................... 8

Dunkard group, character and thickness of. . 27-28

Dunkard sand, character and thickness of... 19

E.

Ewings Mill oil and gas field, wells of, character of ..........................

F.

Fifth sand, character and position of........ 13 structural position of oil and gas in...... 91-92 Finley Township, oil and gas fields of, distri bution and character of ......... 56-60 wells in, records of . . . . . . . . . . . 24,59-60 Finleyville oil and gas fields, wells of, distribution and character of......... 84-85 wells of, records of. ................. 85

Fourth sand, character and position of...... 13-14 structural position of oil and gas in...... 92-93

G.

$G$ as fields, distribution of, maps showIng ..................... 7 ; in pocket. Gas pools, character and distribution of...... 33-91 See also particular townships.

structural position ol .................. 91-96

Gas wells; sections of, plates showing....... 10 typical records of ............... 11-12,20-25

For other records, see particular townships or ficlds.

Geography, features of................. 7-8

Gordon sand, character and position of ..... 14 distance of, to Ṕittsburg coal, map show. ing........................

$83448^{\circ}-$ Bull. $456-11-7$ 
Gordon sand, structural features of structural position of oil and gas in...... 93-94 Gordon Stray sand, character and position of.

H.

Hagman, G. L., work of..

Hopper oil pool, extent and production of $-49-50$

Hundred-foot sand, character and distribution of....................... 15 structural position of oil and gas in..... 95-96

I.

Imperial oil and gas field, Finley and Moon townships, wells of, character of. 56-57 Imperial oil and gas field, North and South Fayette townships, distribution and character of .............. 54-56 wells of, records of................. $55-56$

\section{L.}

Lickskillet oil and gas field, wells of, data regarding.................... 50-51

wells of, records of................. 51

$$
\text { , M. }
$$

McCormich oil and gas field, wells of, distribution and character of...........

McCurdy oil field, wells of, distribution and production of..................

McDonald field, oil production of, diagram showing ......................

oil production of, table showing ..........

McDonald oil field, Cecil Township, wells of, character and distribution of.... 41-43

wells of, records of................. 42-43

McDonald oil field, North and South Fayette townships, wells of, distribution, character, and production of..... 43-49

wells of, records of ................... 46-47

McDonald oil field, Robinson and Stowe townships, wells of, distribution, character, and production of..... 61-62

McDonald oil and gas field, Collier Township, wells of, distribution and character of ..................... 74-76

wells of, records of.................... 76

McMurry gas and oil field, wells of, distribution and character of ........... $86-88$

wells of, records of.................. 88-91

McMurry syncline, structural features of.... $\quad 32$

Mahoning sandstone, character and thickness of . ........................

Martin, G. C., work of.

Mauch Chunk formation, character, position, and thickness of.................

effect of unconformity upon..............

Mawhinney oil pool, location and production of ....................... 38-39

wells of, records of.

Mississippian series, character, distribution, and subdivisions of ........... 15-17

Monongahela formation, character, geologic relations, and subdivisions of .... 26-27

Moon oil pool, wells of, distribution and character of .................. 58-60

wells of, records of.
Moon Run oil field, wells of, distribution and character of .................. $62-69$

wells of, records of ................. $66-69$

Moon Township, oil and gas fields of, distribution and character of...... $50-60$ wells in, records of................... 59-60

Morgantown sandstone, character and position of ..................... 20

Mount Nebo, syncline, structural features of. . 33 Murrysville sand, character and distribution

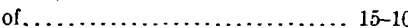

\section{N.}

Nineveh syncline, structural features of......

Nineveh. Thirty-foot sand, character and position of ................... 14-15

structural position of oil and gas in...... 94-95

North Fayette Township, oil and gas fields of, distribution and character of..... 43-56 wells in, records of....... 46-47, 51,52-53,55-56 North Strabane Township, oil and gas fields of, distribution and character of. $85-91$ wells in, records of ................. 88-91

\section{o.}

Oil, production of, in McDonald field, diagram showing ....................

production of, in McDonald field, table showing......................

Oil fields, distribution of, maps showing.................... 7 ;.in pocket.

Oil pools, character and distribution of...... 33-91 See also particular townships.

structural position of ................ 91-96

Oil wells, sections of, plates showing........ 10 typical records of ............... 11-12, 20-25

For other records, see particular townships or fields.

\section{P.}

Peck, George F., work of................... Pennsylvanian series, exposed portion, char、acter, distribution, and subdivisions of ..................... 26-28 unexposed portion, character, distribution, and subdivisions of ........ 18-20

Permian series, character and thickness of ... 27-28 Peters Township, oil and gas fields of, distripution and character of......... 35-91 wells in , records of .............. 22-23,88-91

Physiography, features of............... 7-8 Pittsburg and vicinity, oil and gas fields of, distribution and character of..... 69-74 wells of, records of ......... 11-12; 20-21, 73-74 Pittsburg coal, character and thickness of.... 27 distance of to Gordon sand, map showing. $\quad 30$ Pittsburg sandstone, character and distribution of ..................... 27

Pocono formation, distribution; subdivisions, and thickness of .............. 15-17

Pottsville formation, geologic history and members of.

salt sand of, character and distribution of 19 
R.

Page.

Robinson 'Township, oil and gas fields of, distribution and character of. .... 60-69 wells in, records of.

Rocks, general character of..... 66-69 outcropping, classification and subdivisions of ................... 25-28 subsurface, classification and subdivisions of ....................... 8-25

generalized secticn of ............. 10 source $\mathrm{c} f$ information concerning..... $9-11$ thickness and character of, sections showing..................... 20-25

See also particular systems, series, and formations.

S.

Saltsburg sandstone, character and position of........................

Salt sand, position, distribution, and character of.

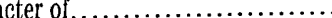

Scott Township, oil and gas fields of, distribution and character of........ 74-78 wells in, records of

Snowden Township, oil and gas fields of, distribution and character of . . .... 82-84

wells in, records of................... 84

South Fayette Township, oil and gas fields of, distribution and character of.... 43-56 wells in, records of...... . 46-47,51, 52-53, 55-56

Stowe Township, oil and gas fields of, distribution and character of........ 60-69 welis in, records of.................. $60-69$

Stratigraphy, features of.............. 8-28

Structure, definitions of . ............... 28

features of ....................... $31-33$

method of representing.............. 28

of Carnegie quadrangle, sketch map showing ............... in pocket.

Structure contours, accuracy of......... 29-31
T.

Page.

Third sand, character and position of....... 14 See Grordon sand.

Third Stray sand, character and position of. . 14

U.

Unconformity, cause of and effect of on Mauch Chunk formation..............

Unexposed strata, classification and subdivisions of ................... 8-25

generalized section showing........... 10

source of information concerning........ 9-11

thickness and character of, well sections showing ................ 20-25

Union Township, oil and gas fields of, distribution and character of........ 84-85

wells in, records of.................. 85

Uniontown sandstone, character and position of......................... 27

Upper St. Clair Township, oil and gas fields of, distribution and character of. . 79-\$2 wells in, records of. $22,79-80,81-82$

$$
\mathrm{V} \text { : }
$$

Venice oil field, wells of, character and distribution of. $39-41$ wells of, records of. $40-41$ W.

Washington anticline, structural features of. .

Washington formation, character and thickness of.................. 27-28

Waynesburg coal, character and position of.. 27 Wells, sections of, plates showing......... 10 typical records of .............. 11-12, 20-25

For other records, sec particular town. ships or ficlds.

Wildwood anticline, structural features of... 32-33 Woodville oil and gas field, wells of, data regarding.................. $76-77$ wells of, records of $\ldots \ldots \ldots \ldots \ldots \ldots \ldots \ldots \ldots$ 